\title{
DEBORA MOREIRA
}

Perfil fenotípico, diferenciação molecular, produção de enzimas e sensibilidade aos antifúngicos de amostras de leveduras isoladas em três grupos amostrais: mulheres assintomáticas, com candidíase vulvovaginal primária e recorrente

Tese apresentada ao Departamento de Microbiologia do Instituto de Ciências Biomédicas da Universidade de São Paulo, para obtenção do Título de Doutor em Ciências.

SÃO PAULO

2012 


\section{DEBORA MOREIRA}

Perfil fenotípico, diferenciação molecular, produção de enzimas e sensibilidade aos antifúngicos de amostras de leveduras isoladas em três grupos amostrais:

mulheres assintomáticas, com candidíase vulvovaginal

primária e recorrente

Tese de Doutorado apresentada ao Instituto de Ciências Biomédicas da Universidade de São Paulo, para obtenção do Título de Doutor em Ciências.

Área de concentração: Microbiologia

Orientadora:

Prof ${ }^{a}$. Dr. ${ }^{\text {a }}$ Claudete Rodrigues Paula

Versão original

SÃO PAULO

2012 


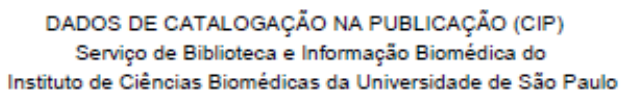

reprodução não autorizada pelo autor

\section{Moreira, Debora.}

Perfil fenotípico, diferenciação molecular, produção de enzimas e sensibilidade aos antifúngicos de amostras de leveduras isoladas em três grupos amostrais: mulheres assintomáticas, com candidiase vulvovaginal primária e recorrente / Debora Moreira. - São Paulo, 2012.

Orientador: Prof Dra. Claudete Rodrigues Paula.

Tese (Doutorado) - Universidade de São Paulo. Instituto de Ciências Biomédicas. Departamento de Microbiologia. Área de concentração: Microbiologia. Linha de pesquisa: Candidiase vulvovaginal.

Versão do título para o inglês: Phenotypic profile, molecular differentiation, production of enzymes and antifungal susceptibility of yeasts isolated from samples in three sample groups: asymptomatic women with primary and recurrent vulvovaginal candidiasis.

Descritores: 1. Candidiase 2. C. albicans 3. Antifúngicos 4. Enzimas hidrolíticas 5. Reação em cadeia por polimerase 6. Eletroforese em gel I. Paula,Profa Dra. Claudete Rodrigues II. Universidade de São Paulo. Instituto de Ciências Biomédicas. Programa de Pós-Graduação em Microbiologia III. Título. 
Candidato(a):

Título da Tese:

Orientador(a):

\section{Debora Moreira.}

Perfil fenotipico, diferenciação molecular, produção de enzimas e sensibilidade aos antifúngicos de amostras de leveduras isoladas em três grupos amostrais: mulheres assintomáticas, com candidiase vulvovaginal primária e recorrente.

Prof Dra. Claudete Rodrigues Paula.

A Comissäo Julgadora dos trabalhos de Defesa da Tese de Doutorado, em sessão pública realizada a J................, considerou

\section{( ) Aprovado(a) $\quad$ ( ) Reprovado(a)}

$\begin{array}{ll}\text { Examinador(a): } & \begin{array}{l}\text { Assinatura: } \\ \text { Nome: } \\ \text { Instituição: }\end{array} \\ \text { Examinador(a): } & \begin{array}{l}\text { Assinatura: } \\ \text { Nome: } \\ \text { Instituição: }\end{array} \\ \text { Examinador(a): } & \begin{array}{l}\text { Assinatura: } \\ \text { Nome: } \\ \text { Instituição: }\end{array} \\ \text { Examinador(a): } & \begin{array}{l}\text { Assinatura: } \\ \text { Nome: } \\ \text { Instituição: }\end{array} \\ \text { Pssinatura: } & \begin{array}{l}\text { Nome: } \\ \text { Instituição: }\end{array}\end{array}$


São Paulo, 25 de setembro de 2009.

\section{PARECER 919 /CEP}

A Comissão de Ética em Pesquisas com Seres Humanos do ICB, na sessão de 24.09.2009 APROvOU o projeto intitulado: "Candidiase vulvovaginal: Perfil fenotípico, genotípico, produção de proteinase (em meio solidoeliquido) e sensibilidade aos antifúngicos de amostras de leveduras isoladas como colonizantes e como agentes de candidiase vulvovaginal primária e recorrente" sob responsabilidade de execução dos autores Profa. Dra. Claudete Rodrigues Paula e a aluna Débora Moreira.

Cabe aos pesquisadores executantes elaborar e apresentar a este Comitê, relatórios anuais (parciais ou final), de acordo com a resolução 196/06 do Conselho Nacional da Saúde, item IX.2 letra c.

O primeiro relatório deverá ser encaminhado à Secretaria deste CEP em

\subsubsection{0}

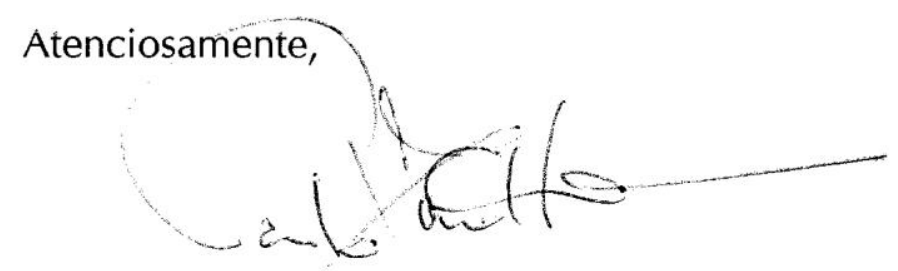

Prof. Dr. PaOlo Marinho ANDRAde ZanotTo

Vice-Coordenador da Comissão de Ética em

Pesquisas com Seres Humanos - ICB/USP 
Feliz é aquele que teme ao Senhor... $E$ anda em seus caminhos Salmos 128:1 
Ao meu pai, José Luiz, e a minha mãe Lourdes, Que sempre me apoiaram: Amo vocês. Aos meus irmãos, Joede e Damaris e aos meus cunhados Cláudio e Débora, Pelos momentos compartilhados, Aos meus sobrinhos Pedro, Felipe, Duda e Aninha que me fizeram ver que o valor da vida está nos pequenos gestos. 


\section{AGRADECIMENTOS}

A minha orientadora Profa. Dr. a Claudete Rodrigues Paula "Teacher": Por ser a minha grande incentivadora; por me deixar "Voar"; pelos dez anos de convivência; pela paciência; pelo companheirismo; pela transmissão de conhecimentos. Enfim, pela amizade e compreensão em todos os momentos.

A Deus, que me concedeu tudo o que tenho de mais precioso.

Ao Laboratório de Micologia, do Departamento de Microbiologia, pelo programa de Pós Graduação.

Ao Cnpq e à Fapesp, pelo auxílio financeiro.

Aos professores Dr. Valderez Gambale e Dr. Flavio Alterthun pelo convívio tão amável em nosso laboratório.

Ao Dr. Luiz Jorge Fagundes, da Faculdade de Saúde Pública e a Bióloga Fátima, pelo apoio, nas coletas.

A especialista em Microbiologia Maria José (minha atual "chefa"), pelos conhecimentos transmitidos, durante a realização das coletas e pela convivência harmoniosa, na Controlbio e aos meus colegas de trabalho.

Ao Prof. Dr. Arnaldo César Colombo, por permitir a realização de experimentos, em seu laboratório e a todos os alunos, em especial, a Angela e a Karina.

A pesquisadora $\mathrm{Dr}^{\mathrm{a}}$ - Walderez Szeszs e Dr ${ }^{\mathrm{a}}$ Marcia de Souza Carvalho Melhem, pesquisadoras do Instituto Adolfo Lutz, que tanto contribuíram para esse estudo.

Aos meus amigos Fábio, Anita, Sandra e Elza... quem tem amigos, tem tudo....

A minha amiga Vanessa, pelo apoio, e aos amigos do Laboratório de Micologia, a Elizângela, ao Prof. Dr. Marcos Auler, Prof ${ }^{a}$ Dr $^{\text {a }}$ Amanda, Ériques, Luciana "Lu", Diana, Bruno, Georgea e Satiko, pelos momentos compartilhados. Às estagiárias Luciana, Ana Luiza e Diana, que fizeram parte desse trabalho.

Aos funcionários da Esterilização. À secretaria da Pós Graduação e aos funcionários da biblioteca do ICB, que me auxiliaram na revisão da tese.

Afinal, agradeço a todos que me apoiaram em algum momento da minha vida e que contribuíram para a realização de mais um sonho. 


\section{RESUMO}

Moreira, D. Perfil fenotípico, diferenciação molecular, produção de enzimas e sensibilidade aos antifúngicos de amostras de leveduras isoladas em três grupos amostrais: mulheres assintomáticas, com candidíase vulvovaginal primária e recorrente. $155 \mathrm{f}$. Instituto de Ciências Biomédicas, Universidade de São Paulo, São Paulo, 2012.

O presente estudo foi realizado com 258 mulheres, com e sem sintomas de candidíase vulvovaginal, atendidas no Centro de Saúde "Geraldo Paula Souza", da Faculdade de Saúde Pública da USP. Leveduras foram isoladas em 162 mulheres, sendo que 34\% foram de mulheres assintomáticas, 34\% com sintomas de candidíase vulvovaginal primária (CVV) e 32\% com candidíase vulvovaginal recorrente (CVVR). As espécies mais isoladas foram $C$. albicans, C. parapsilosis, C. glabrata e C. tropicalis. Espécies como C. metapsilosis e C. haemulonii também foram encontradas. A produção de proteinase foi vista em $88 \%$ das amostras e de fosfolipase foi de $39 \%$. A sensibilidade "in vitro" aos antifúngicos foi realizada pelo "Etest" e, nos isolados resistentes a anfotericina $B$, fluconazol e itraconazol foram realizados ensaios de microdiluição (CLSIM27S3) e EUCAST EDef7.1, que confirmaram a diminuição da sensibilidade ao itraconazol em isolados de C. parapsilosis (1); C. guilliermondii (1), C. glabrata (3) e Trichosporon spp (1). A diminuição da sensibilidade ao fluconazol foi observada em isolados de C. parapsilosis (1), C. glabrata (3), C. krusei e Rhodotorula spp (1). As leveduras do grupo das CVVRs foram as que apresentaram menor sensibilidade. Em 61 isolados de várias espécies foi realizada a cariotipagem em campo pulsado (PFGE) e não foram observadas similaridade entre elas. Os dados obtidos reforçam a importância da realização de exames laboratoriais que permitam identificar as espécies presentes no conteúdo vaginal, de modo a nortear a escolha terapêutica.

Palavras chaves: Candidíase. C. albicans. Antifúngicos. Enzimas hidrolíticas. Reação em cadeia por polimerase. Eletroforese em gel (PFGE) 


\begin{abstract}
Moreira, D. Phenotypic profile, molecular differentiation, production of enzymes and antifungal susceptibility of yeasts isolated from samples in three sample groups: asymptomatic women with primary and recurrent vulvovaginal candidiasis. 155 p. 2012. Master thesis (Microbiology). Instituto de Ciencias Biomedicas [Biomedical Sciences Institute], Universidade de São Paulo, São Paulo, 2012.

This study was conducted with 258 women, with and without symptoms of vulvovaginal candidiasis, seen at the Health Center "Geraldo Paula Souza", School of Public Health of USP. Yeasts were isolated in 162 women, 34\% of women were asymptomatic, 34\% with primary symptoms of vulvovaginal candidiasis (VVC) and $32 \%$ with recurrent vulvovaginal candidiasis (CVVR). The species were more isolated $C$. albicans, $C$. parapsilosis, C. glabrata and $C$. tropicalis. Species such as $C$. metapsilosis and $C$. haemulonii were also found. The production of proteinase was seen in $88 \%$ of the samples and phospholipase was 39\%. Sensitivity "in vitro" Antifungal was by the "Etest" and in isolates resistant to amphotericin B, fluconazole and itraconazole microdilution tests were performed (CLSIM27S3) and EUCAST EDef7.1, which confirmed the decreased sensitivity to itraconazole in isolates $C$. parapsilosis (1), C. guilliermondii (1), C. glabrata (3) and Trichosporon spp (1). The decreased sensitivity to fluconazole was observed in isolates of C. parapsilosis (1), C. glabrata (3), C. krusei and Rhodotorula spp (1). Yeasts of the group CVVRs were those who had lowest sensitivity. In 61 isolated from various species karyotyping was performed pulsed field (PFGE) and there were no similarity between them. The data emphasize the importance of laboratory tests to identify the species present in the vaginal content in order to guide the therapeutic choice.
\end{abstract}

Key works: Candidiasis. C. albicans. Antifungal. Hydrolytic enzymes. Polymerase chain reaction. Gel electrophoresis. 


\section{LISTA DE FIGURAS}

Figura 1: Expressão de SAPS e a função fisiológica associada a cada um

dos genes

Figura 2: Localização das regiões ITS 1 e ITS

Figura 3: Variação de Idade, por grupo amostra

Figura 4: Cultivo de Candida albicans em CHROMagar

Figura 5: Cultivo de $C$. dubliniensis em CHROMagar

Figura 6: Cultivo de $C$. tropicalis, em

Figura 7: Cultivo de C. parapsilosis em CHROmagar

Figura 8: Cultivo de C. glabrata em CHROmagar

Figura 9: Cultivo de Candida albicans em ágar Sabouraud dextrose

Figura 10: Cultura de Rhodotorula spp em ágar Sabouraud dextrose

Figura 11: Microcultivo em lâmina de $C$. albicans

Figura 12: Microcultivo em lâmina de $C$. haemuulonii

Figura 13: Microcultivo em lâmina de C. glabrata

Figura 14: Microcultivo em lâmina de $C$. parapsilosis

Figura 15: Microcultivo em lâmina de $C$. tropicalis

Figura 16: Bandas exibidas por Candida spp em gel de agarose

Figura 17: Alinhamento dos nucleotídeos, gerados no Blast

: Figura 18: Frequência de leveduras isoladas da região vulvovaginal, identificadas através de provas fisiológicas e sequenciamento

Figura 19: Frequência de leveduras, por grupo amostral

Figura 20: Indice de proteinase em todas as amostras

Figura 21: Comparação da produção de proteinase, por grupo amostral

Figura 22: Produção de proteinase por espécies pertencente ao

Figura 23: Produção de proteinase por espécies pertencente ao grupo das CVV

Figura 24: Produção de proteinase por espécies pertencente ao grupo das CVVRs

Figura 25: Indice geral de produção de fosfolipase pelas espécies de leveduras

Figura 26: Comparação da produção de fosfolipase, pelos grupos amostrais

Figura 26: Perfil cromossômico de diferentes isolados de Candida spp, através do PFGE em gel de agarose a $0,8 \%$

Figura 27: Dendograma dos isolados de Candida glabrata, a partir das bandas eletroforéticas

Figura 28: Dendograma dos isolados de Candida kefyr, a partir das bandas eletroforéticas

Figura 29: Dendograma dos isolados de Candida tropicalis, a partir das bandas eletroforéticas

Figura 30: Dendograma dos isolados de Candida albicans, a partir 
Figura 31: Dendograma dos isolados de Candida parapsilosis, a partir das bandas eletroforéticas 


\section{LISTA DE TABELAS}

Tabela 1: Características bioquímicas das Saps 25

Tabela 2: Diferenças entre os métodos CLSI M27S3 e o Eucast EDef7.1 43

Tabela 3: Atividade enzimática (proteinase e fosfolipase) conforme o PZ e o código 54

Tabela 4: Interpretação do comportamento de cepas de Candida spp 56

frente à concentração dos antifúngicos $(\mu \mathrm{g} / \mathrm{mL})$, segundo documentos CLSI M27S3

Tabela 5: Desempenho da coloração do esfregaço pelo método de Gram, em relação a 63

cultura, para a confirmação do diagnóstico de Candida spp

Tabela 6: Avaliação da cultura, em relação a coloração do esfregaço pelo Gram, para diagnóstico de candidiase vulvovaginal

Tabela 7: Relação de concordância entre os métodos convencionais e CHROMagar de para a confirmação da espécie de levedura

Tabela 8: Perfil fisiológico de amostras identificadas como Candida spp não classificadas pelos métodos de identificação tradicional

Tabela 9: Características fenotípicas semelhantes de $C$. dubliniensis

Tabela 10: Identificação de através de provas fisiológicas e características apresentadas em meio cromogênico

Tabela 11: Resultado do sequenciamento das amostras

Tabela 12: Produção de proteinase, por espécie de levedura

Tabela 13: Produção de fosfolipase, por índice e por espécie

Tabela 14: Valores de CIM apresentados amostras de leveduras pelo método do Etest

Tabela 15: Variação de $\mathrm{CIM}_{50}$ e CIM 90 , sensibilidade e resistência de isolados de leveduras

Tabela 16: Comparação dos resultados obtidos pelo "Etest" com os demais métodos para a anfotericina $B$

Tabela 17: Perfil de SDD e R ao itraconazol das 29 amostras frente aos três métodos de antifungigrama

Tabela 18: Perfil de sensibilidade dose dependente e resistência ao fluconazol das 12 amostras frente aos três métodos

Tabela 19: Perfil das amostras que apresentaram resistência ou sensibilidade dose dependente, através do método de referência: CLSIM27S3 
1.1 Leveduras do gênero Candida spp 18

1.2 Presença de Candida no conteúdo vaginal 18

1.3 Fatores predisponentes a colonização do trato genital e ao 20 desenvolvimento de infecção

1.4 Fatores relacionados à virulência das leveduras 22

1.5 Espécies de Candida spp envolvidas na candidíase vulvovaginal

1.6 Sinais e sintomas clínicos de CVV 33

1.7 Diagnóstico Laboratorial 34

1.7.1 Identificação Tradicional 34

1.7.2 Métodos moleculares de diagnóstico de CV 35

1.7.2.1 Reação em Cadeia de Polimerase (PCR) e sequenciamento 36

1.8 Tratamento da CVV

1.9 Testes de Susceptibilidade $\quad 41$

2.0 Objetivos $\quad 45$

2.1 Objetivos Gerais $\quad 46$

2.2 Hipóteses a serem testadas 46

3 Material e métodos $\quad 47$

3.1 Mulheres que participaram do estudo 48

3.1.1 Coleta do material vaginal $\quad 48$

3.2 Definições dos grupos 48

3.3 isolamento e condições de crescimento 49

3.3.1 Diferenciação entre C. albicans e C. dubliniensis 49

3.3.1.1 Diferenciação em "CHROMagar Candida $® " ~ 49$

3.3.1.2 Crescimento a $45^{\circ} \mathrm{C} \quad 50$

3.3.1.3 Caldo Sabouraud hipertônico 50

3.3.1.4 Diferenciação molecular das amostras sugestivas de $C$.
dubliniensis

3.3.2 Diferenciação das amostras de leveduras pertencentes ao complexo

C. parapsilosis strictu sensu $\quad 51$

3.3.3 Identificação das leveduras que não foram identificadas pelas 51 provas fisiológicas: Candida spp

3.4 Reação de Polimerase em Cadeia (PCR) e Sequenciamento 51

3.4.1 Extração de DNA das Leveduras

3.4.2 Amplificação. $\quad 52$

3.4.3 Sequenciamento $\quad 53$

3.5 Determinação dos fatores relacionados a virulência

3.5.1 Pesquisa de Proteínase (Sap`s) 53

3.5.2 Pesquisa da Fosfolipase 54

3.6 Determinação dos Perfis de Sensibilidade e de Resistência “in
vitro" às Drogas Antifúngicas

3.6.1 "Etest

3.6.2 Microdiluição

3.6.2.1 CLSI M27S3 56

3.6.2.2 EUCAST EDef 7.1 58

3.7 Cariotipagem através da técnica Eletroforese em Campo Pulsado

$\begin{array}{ll}\text { (Pfge) } & 58 \\ \text { 3.7.1 Extração de DNA } & 58\end{array}$

3.7.2 Corrida Eletroforética $\quad 59$

3.8 Análise Estatística $\quad 60$

4 Resultados $\quad 61$ 
4.1 Mulheres que participaram do estudo 62

4.1.1 Coleta de material vaginal 62

4.1.1.1 Coloração do esfregaço pelo método de Gram e cultura

4.2 Definições de grupos amostrais 64

4.3 Identificação morfológica dos isolados de Candida spp

4.3.1 Características Fenotípicas

4.3.1.2 Identificação de Trichosporon spp

4.3.2 Características Fisiológicas 70

4.3.2.1 Diferenciação de C. albicans e C. dubliniensis

4.3.2.2 Complexo C. parapsilosis strictu sensu

4.4 PCR e Sequenciamento das Candida spp Selecionadas para os Estudos Moleculares

4.4.1 Reação em Cadeia da Polimerase (PCR) 75

4.4.2 Amplificação da Região ITS pela Reação em Cadeia por Polimerase (PCR)

4.5 Sequenciamento dos Produtos da PCR

4.6 Identificação das leveduras $\quad 77$

4.6.1 Correlação Entre as Espécies e os grupos de Mulheres
Assintomáticas, com CVV e com CVVR

4.7 Produção de Exoenzimas $\quad 81$

$\begin{array}{ll}\text { 4.7.1 Proteinase } & 81\end{array}$

4.7.2 Correlação entre proteinase e o grupo amostral 83

4.7.3 Correlação entre a produção de proteinase, as espécies e os grupos

$\begin{array}{ll}\text { 4.8 Fosfolipase } & 85\end{array}$

4.8.1 Correlação entre a produção de fosfolipase, as espécies e os grupos amostrais

4.9 Sensibilidade aos antifúngicos $\quad 88$

4.9.1 "Etest"

4.9.2 Microdiluição (Eucast Edef7.1 e CLSI) 91

4.9.3 Resistência a anfotericina B 91

4.9.4 Resistência ao itraconazol 92

4.9.5 Resistência ao fluconazol 92

4.10 Perfil genotípico 95

4.10.1 Tipagem molecular das leveduras isoladas 95

4.10.2 Estimativa do peso molecular das bandas de Candida Spp 96

5 Discussão $\quad 101$

6 Conclusão. $\quad 125$

$\begin{array}{ll}7 \text { Referência } & 127\end{array}$

Anexos $\quad 150$

Anexo A: Protocolo de Avaliação Clínica

Anexo B: Avaliação Laboratorial 152

Anexo C: Termo de consentimento 153 
1 Introdução 


\subsection{Leveduras do gênero Candida Spp}

As leveduras do gênero Candida estão normalmente presentes como células individuais que se replicam de forma assexual por blastoporação ou por gemulação (SCHULZE; SONNENBORN, 2009).

Candida albicans é uma levedura polimórfica com oito pares de cromossomos. Pode se aeróbica ou pode se replicar em condições microaerófila, como quando presente no cólon humano. Entre as 314 espécies conhecidas, cerca de doze são consideradas como patogênicas para o homem Uma das razões para que o número de espécies patogênicas seja limitado é que dois terços das leveduras são incapazes de crescer a $37^{\circ} \mathrm{C}$ (SCHULZE; SONNENBORN, 2009).

As leveduras são classificadas como patógenos oportunistas. Por exemplo, quando ocorre mudanças na composição da microbiota do trato gastrointestinal por ação dos antimicrobianos ou deficiência de parâmetros específicos do sistema imunológico, podem favorecer a transformação da levedura da forma comensal para a forma patogênica. Esses danos podem se manifestar em dois níveis: infecções superficiais, da pele, membranas mucosas ou epitélios; e penetração invasiva dos tecidos, com distribuição ao sangue e disseminação para vários órgãos (SCHULZE; SONNENBORN, 2009).

\subsection{Presença de Candida no conteúdo vaginal}

A presença de Candida spp na mucosa vaginal, na ausência de sinais e sintomas de doença indica que há a colonização assintomática (ACHKAR; FRIES, 2010). Estudos indicam que cerca de 20 a $30 \%$ das mulheres saudáveis são portadoras assintomáticas de leveduras (BEIGI et al., 2004; GUZEL et al., 2011).

Esta colonização pode estar associada a diferentes fontes como: propagação local do trato gastrointestinal e do períneo, pela introdução digital e por transmissão sexual (NYIRJESY, 2008).

Logo após o nascimento, inicia-se a colonização do trato gastrointestinal, com micro-organismos que irão compor a chamada microbiota também chamada de 
"microflora intestinal". Mais de 99\% da microbiota é composta por bactérias. Em adição, as espécies de Candida podem ser detectadas no trato gastrointestinal de aproximadamente $96 \%$ dos neonatos, no primeiro mês de vida. O processo de constituição da microbiota é completo entre três e cinco anos, e cada indivíduo apresenta uma microbiota compatível com o seu sistema imunológico (SCHULZE; SONNENBORN, 2009).

Durante o crescimento dentro do trato gastrointestinal, o organismo se adapta às condições de $\mathrm{pH}$, oxigênio, fontes de carbono e a presença de receptores de superfície que Ihes permite otimizar a expressão de genes em um ambiente particular. Com esses mecanismos, as leveduras do gênero Candida são capazes de colonizar o trato gastrointestinal na infância, estabelecendo, assim, um dos nichos naturais mais importantes (ROSENBACH et al., 2010). Essa colonização intestinal pode favorecer a migração da levedura para a região vulvovaginal.

White et al. (2007) sugerem que durante a colonização o tamanho da população de micro-organismos reflete um equilíbrio entre as forças externas que limitam a população, como os efeitos do sistema imune do hospedeiro e, fatores intrínsecos, como a capacidade do micro-organismo em aumentar de número. Na fase adulta, cerca de $70 \%$ dos indivíduos apresentam colonização por fungos, sendo muitos desses do gênero Candida.

A microbiota normal pode estimular os receptores "toll-likes" e essas interações são importantes para a regulação da resposta inflamatória. Na ausência dos receptores "toll likes", pode ocorrer um desequilíbrio da resposta inflamatória, o que pode causar danos aos hospedeiro.

Além disso, as leveduras possuem a capacidade de regular o crescimento de sua população, através da expressão de reguladores que parecem ser fatores que podem auxiliar na manutenção do equilíbrio entre a colonização e o desenvolvimento da doença.

A expressão de genes em células colonizadas mostra padrões distintos de células provenientes de laboratório. Essa expressão é semelhante a apresentada pelas células que estão na fase estacionária do crescimento. Nessa fase, os genes expressos tem a capacidade de conferir resistência ao "stress" oxidativo e possuem a capacidade 
de manter o crescimento do micro-organismo em condições nutricionais desfavoráveis (ROSENBACH et al., 2010).

Além desses, alguns clones de $C$. albicans podem expressar genes característicos da fase exponencial. Isto pode ser resultante da existência de várias subpopulações de células, em diferente estado fisiológico (ROSENBACH et al., 2010).

A combinação deste estado fisiológico dessas células com a capacidade da célula crescer rapidamente e a resistência ao estresse, pode produzir um mecanismo fisiológico que se adapte a colonização ao hospedeiro.

Outra fonte de infecção importante é a transmissão sexual. Através de estudos "in vitro", Southern et al. (2008) demonstraram que há uma aparente facilidade de Candida spp se aderir às células epiteliais e aos fibroblastos. No entanto, a secreção de muco, pelas células epiteliais endocervicais pode conferir uma proteção contra essa colonização. Porém, quando há o aparecimento de microlesões na superfície célular, o epitélio é exposto o que favorece a adesão das leveduras à mucosa vaginal. As microlesões são comumente encontradas em mulheres jovens, com o inicio da atividade sexual.

\subsection{Fatores predisponentes a colonização do trato genital e ao desenvolvimento de infecção}

Há vários fatores que podem ser considerados predisponentes a colonização da mucosa vaginal por Candida spp. Um desses seria o fator genético. Em um estudo realizado com modelo animal, Calderon et al. (2003) perceberam que diferentes linhagens de camundongos reagem a diferentes formas à colonização por Candida spp, indicando que existem alguns fatores, ainda não bem esclarecidos que envolvem a colonização. Alguns estudos recentes demonstram que a deficiência da expressão de lectina nas células dos hospedeiros podem favorecer a colonização por Candida spp.

A elevação dos níveis de estrógeno pode ser considerada como outro fator importante para o aumento da colonização por Candida. Esta condição pode ser observada em mulheres portadoras de "diabetes mellitus" (PIROTTA; GARKABD, 2006) e durante a gestação, os estudos indicam que entre 10 e 50\% das mulheres grávidas podem ser colonizadas por leveduras. Outro fator que pode favorecer a colonização por 
Candida spp é o uso de contraceptivos orais a base de estrógeno. Esses fatores podem resultar no aumento dos níveis de glicogênio circulante, favorecendo, assim, a colonização (GUZEL et al., 2011).

Após a colonização, as leveduras podem permanecer durante longo período sem produzir sintomas. Para Cassone et al. (2007), essa permanência da levedura sobre a superfície da mucosa não passa despercebida pelo sistema imunológico e nem é simplesmente tolerada pelo hospedeiro. Para ele, há mecanismos da resposta imune inata e humoral que conseguem restringir o crescimento do fungo e neutralizar a sua virulência.

Porém, quando esses mecanismos falham ocorre o desenvolvimento de candidiase vulvovaginal (CVV). Dados mostram que $75 \%$ das mulheres em idade fértil apresentam pelo menos um episódio de candidiase ao longo da vida e, aproximadamente $5 \%$ das mulheres apresentam episódios freqüentes e refratários, com mais de quatro episódios ao ano (ACHKAR; FRIES, 2010; SOBEL, 2007).

Diversos estudos têm sido realizados no sentido de esclarecer quais são as causas e como ocorre a transformação da levedura da forma comensal para a patogênica. De acordo com Sobel (2007) estes eventos são multifatoriais e envolve fatores relacionados ao hospedeiro e aos micro-organismos.

Para Martinez et al. (2009) o desenvolvimento de candidiase vulvovaginal (CVV) é resultante de um aumento exagerado no número de Candida spp. As causas para esse super crescimento seria o uso de antibacterianos e de duchas vaginais (CHENG et al., 2010) que poderiam levar a diminuição do número de lactobacilos.

Os lactobacilos estão presentes na vagina de mulheres em idade fértil e sua função é prevenir o aumento no número de patógenos através da produção de ácidos, bacteriocinas, biossulfactantes, peróxido de hidrogênio e moléculas coagregativas. Os lactobacilos e as leveduras podem ser encontradas na vagina de mulheres saudáveis. Contudo, a diminuição dos lactobacilos proporciona um super crescimento das leveduras. e essas são capazes de destruir as células epiteliais por invasão direta e causar a liberação de substâncias como as prostaglandinas e bradicininas que levam a inflamação vulvovaginal (vaginites). Esta invasão pode estar associada a capacidade 
das leveduras em produzir enzimas extracélulares, como proteases e fosfolipases (MARTINEZ et al., 2009).

Beigi et al. (2004) sugerem que vários fatores relacionados aos hospedeiros como portadores de HIV, com diabetes, que fazem uso de contraceptivos orais e o uso recente de antimicrobianos favorecem essa transformação (MASHBURN, 2006). Em mulheres que apresentam atopia ao contato com produtos químicos, alergia local ou reações de hipersensibilidade o meio vaginal pode ser alterado, facilitando a transformação do estado de colonização para vaginite sintomática (SHAH et al., 2006).

\subsection{Fatores relacionados à virulência das leveduras}

As leveduras patogênicas podem codificar genes que são específicos para a patogenicidade e outras propriedades importantes no processo de infecção. Esses fatores incluem adesinas, que mediam a ligação da levedura à superfície célular, como os fatores de agregação ao epitélio e endotélio, que incluem as proteínases aspárticas secretadas, as fosfolipases e as lipases.

O primeiro passo para que ocorra a infecção é a interação com as células hospedeiras. As leveduras do gênero Candida são capazes de expressar várias adesinas, com capacidade de quebrar as proteínas da matriz extracélular das mucosas e das células endoteliais (SUNDSTROM, 2002).

As proteínas que mediam a aderência e a invasão de Candida spp as células hospedeiras tem sido foco de numerosas investigações.

Os genes da família de sequências tipo aglutinina (Als) são adesinas amplamente estudadas em $C$. albicans. Estas adesinas são codificadas por uma família de genes ALS composta de nove integrantes distintos presentes no genoma de $C$. albicans.

As proteínas ALS têm três diferentes domínios. O primeiro é $\mathrm{N}$ terminal, constituído por aproximadamente 433 aminoácidos que, provavelmente estão relacionados com a função adesiva. A região central de domínio consiste em regiões repetitivas com essa sequencia de aminoácidos. O domínio C terminal varia de 
comprimento e, apresenta sequências variadas, mas, todas as proteínas desta região estão fortemente ligadas por carboidratos com a região $\mathrm{N}$ terminal (ZHAO et al., 2004)

Em cada proteína Als madura, há uma região $\mathrm{N}$ terminal em uma região chamada de T, que apresenta um domínio variável denominado de TR (FRANK et al., 2010). Por exemplo, Filler 2006 descreve que Als1p e Als3 mediam a aderência às células epiteliais da mucosa oral e às células do endotélio vascular. Alsp5 liga-se à matriz extracelular (FILLER, 2006).

Em C. glabrata, o maior grupo de adesinas é codificado pela família de genes EPA (adesinas epiteliais). A estrutura dessas proteínas é semelhante a das ALS, de C. albicans, contudo, a diferença entre elas está no fato de que a expressão gênica da EPA é governada por silenciadores subteloméricos, enquanto a expressão de ALS é governada por outros mecanismos (FRANK et al., 2010).

Outra importante adesina de Candida spp é a Hwp1 (proteína 1 de parede de hifa), encontrada exclusivamente na superfície do tubo germinativo e que regula ligações fortes das leveduras às células hospedeiras. Estudo realizado por Naglik et al., com amostras provenientes de mulheres portadoras assintomáticas e sintomáticas de leveduras, mostrou que a expressão de Hwp1estava presente em ambos os casos. Nas mulheres que foram utilizadas como controle negativo, a Hwp1 não foi detectada. Esse fato sugere que a função dessa adesina pode estar relacionada ao processo de adesão do micro-organismo ao tecido do hospedeiro (NAGLIK et al., 2006).

Um grande número de proteínas de matriz extracelular (ECM) são expressas por C. albicans, como as de colágenos tipo um e quatro, lamininas, fibrinogênio, fibronectinas e elastinas. Essas proteínas contribuem para a virulência da levedura pois formam uma complexa rede proteica que fornece múltiplos sítios para fixação do microorganismo, aumentando assim, a eficácia da interação célula com célula e matriz célula (CHAFIN, 2008).

Dentre essas funções de virulência estão a produção de enzimas que facilitam a hidrólise das membranas celulares dos hospedeiros, favorecem a adesão e invasão do tecido, ou causam danos as células e moléculas do sistema de defesa do hospedeiro (NAGLIK et al., 2003a). 
A família de genes SAP é a melhor caracterizada em termos de padrões de expressão, durante a infecção por Candida spp. Dependendo da situação, diferentes genes são expressos e exercem papel fundamental na invasão dos tecidos e órgãos (NAGLIK 2003a, 2008; SCHULZE; SONNENBORN, 2009).

As proteinases são classificadas com base em seu mecanismo catalítico e não de acordo com a origem, sitio anatômico, tipo de substrato ou função fisiológica, Classicamente, as proteinases foram distinguidas em quatro classes, que são serino protease, cisteína, metaloprotease e aspartil proteinase.

A atividade proteolítica de C. albicans está relacionada com uma família de 10 proteinases aspárticas (Sap), com peso molecular que varia de 35 a 50kDa codificadas, pelos genes SAP1-10 (NAGLIK et al., 2003b; CHAFFIN, 2008; DABAS; MORCHHÄUSER, 2008). Saps 1-8 são liberadas para o meio extracelular e as Saps 9 e 10 são consideradas proteínas de superfície (WILLIAMS; LEWIS, 2011). Através de análise filogenética observou-se que os produtos da Sap1 a Sap3 e Sap4 e Sap6 são aproximadamente 67 e 89\% idênticos, respectivamente (CHAFFIN, 2008).

As proteinases Saps foram purificadas e caracterizadas através de sobrenadantes de cultura de células crescidas em meio contendo albumina bovina (BSA) em pH 5. Contudo, na literatura, há trabalhos que relatam a utilização de vários meios de cultura para a expressão das Saps (WHITE; AGABIAN, 1995). Em meio contendo nitrogênio como única fonte de proteína, ocorre uma perda significativa de Sap2, Sap4 e Sap6, contudo, a deleção de Sap2 torna $C$. albicans incapaz de crescer em meio "Yeast Carbon Base" albumina bovina, que contém albumina bovina como única fonte de nitrogênio. Staib et al. (2002) suportam a ideia de que a capacidade de C. albicans utilizar nitrogênio pode ser importante para o crescimento da leveduras em certos nichos do hospedeiro. As características das Saps estão descritas na Tabela 1. 
Tabela 1: Características bioquímicas das Saps

\begin{tabular}{l|c|c|c|c|}
\hline Gene & Massa mol (kDa) & Atividade ótima de pH & Ponto isoeletrico & Referência \\
\hline SAP1 & 38 & $3.2-4.5$ & 4 & Borg-von Zepelin et al. 1998 \\
\hline SAP2 & 40 & $3.2-3.5$ & 4.25 & Borg-von Zepelin et al. 1999 \\
SAP3 & 41 & $3.2-3.5$ & 5.7 & Borg-von Zepelin et al. 2000 \\
\hline SAP4 & 40 & 5 & ne & Borg-von Zepelin et al. 2001 \\
\hline SAP5 & 37 & 5 & ne & Borg-von Zepelin et al. 2002 \\
SAP6 & 40 & 5 & ne & Borg-von Zepelin et al. 2003 \\
SAP7 & ne & ne & ne & Borg-von Zepelin et al. 2004 \\
\hline SAP8 & 41 & ne & ne & Morrison et al. 1993 \\
SAP9 & ne & ne & ne & \\
\hline SAP10 & ne & & ne & \\
\hline
\end{tabular}

ne: não encontrado. Técnica: SDS

Fonte: adaptado por Naglik et al. (2003a)

A atividade ótima de $\mathrm{pH}$ difere na expressão das Saps. A atividade ótima dessas enzimas é, em geral, em pH ácido. Este fato pode ser uma desvantagem em potencial, desde que os tecidos dos hospedeiros são mais neutros que ácidos. Candida spp é um comensal da vagina, com um $\mathrm{pH}$ ácido e da cavidade oral, que tem $\mathrm{pH}$ neutro. $\mathrm{O} \mathrm{pH}$ normal do sangue é em torno de 7.4. Para compensar, há algumas respostas diferentes entre a expressão de Saps em resposta ao pH. A atividade de $\mathrm{pH}$ é entre 2 a 7. Sap1-3 tem atividade alta em valores de $\mathrm{pH}$ menor, de 3 a 5, enquanto Sap4-6 tem atividade entre pH 5 a 7 (CHAFFIN, 2008).

Todas as espécies de Candida secretam Saps, contudo, essa expressão pode variar de uma espécie para outra. As espécies de Candida consideradas mais patogênicas, como C. albicans (XU et al., 2005; SIKORA et al., 2011), C. dubliniensis, C. tropicalis (SIKORA et al., 2011) têm maior expressão de Saps mas, de acordo com Trofa et al. (2008), a expressão de Saps em C. parapsilosis é menor do que em $C$. albicans, porém, não foi observado ausência de atividade das Saps em isolados clínicos incomuns, como C. kefyr, C. guilliermondii (NAGLIK et al., 2004) e C. glabrata (LIAN; LIU, 2007).

Vários trabalhos, realizados "in vitro", demonstram que há padrões distintos da expressão de Saps, nas leveduras, nos diferentes estágios de infecção (NAGLIK et al., 2004). Em estudo realizado por Naglik et al. (2003b), o autor utilizou células epiteliais humanas provenientes da mucosa vaginal e infectou essas células com leveduras provenientes de 130 indivíduos portadores assintomáticos e com infecção por Candida 
spp. O autor concluiu que, todos os membros da família Sap foram expressos durante a colonização e durante o período patogênico (desenvolvimento da doença); certos genes SAP podem ser papel mais expressivo durante a infecção.

A conclusão de que as Saps são expressas em portadores assintomáticos de leveduras é baseada em vários trabalhos. Ripeau et al. (2002) demonstraram que em modelo animal de candidiase orofaríngea, Sap1-6 e Sap9 foram detectadas continuamente, durante todo o processo de infecção. Para Cassone et al. (2002) em infecção gastrointestinal, Sap4 e 6 foram continuamente expressa, e que Saps2, 3 e 5 ocasionalmente foram detectadas. Conclusão similar chegou Felk et al. (2002), em infecção intraperitoneal. Esses dados indicam que a expressão e regulação dos genes SAPS depende do tipo e do estágio da infecção por Candida spp e que $0 \mathrm{pH}$ e 0 substrato são de extrema importância para a expressão desses genes (NAGLIK et al., 2004).

O papel exercido pelas Saps "in vivo" tem sido objeto de vários estudos. Os meios de cultura utilizados, normalmente, favorecem a expressão da Sap2 e essa tem sido a mais estudada.

De acordo com Moschhäuser et al. (1997) a atividade da Sap2 está relacionada com a degradação de varias proteínas presentes na mucosa dos hospedeiros incluindo a queratina, o colágeno, a vimectina, a fibronectina, a laminina e a mucina. A eficiente remoção das barreiras dos hospedeiros poderia não somente melhorar o aporte nutricional para as células, como também poderia facilitar a adesão, colonização, penetração aos tecidos do hospedeiro e disseminação da Candida spp para o sistema circulatório (NAGLIK et al., 2004).

O papel exercido pela Sap2, na aderência, invasão e infecção pode ser confirmado pela adição de pepstatina A, em ensaios "in vitro". A adição deste inibidor de protease leva uma inibição da digestão da mucina, indicando que as proteinases expressas pelas espécies de Candida podem degradar as proteínas de barreiras, presente nas mucosas (FALLON et al., 1997).

A primeira função atribuída as SAPS4-6 estavam relacionadas a formação de hifas, em valores de pH neutro (CHAFFIN, 2008; WHITE; AGABIAN, 1995;). Contudo, os estudos prosseguiram e, Hube et al. (1997) propuseram que a função desses genes 
estaria relacionada às infecções sistêmicas e que essas SAPS não participariam da patogenicidade das infecções superficiais. Porém, Felk et al. (2002) propuseram que os genes SAP4-6 estavam envolvidos com a evasão do sistema imunológico.

A produção de Sap8 é regulada pela temperatura, sendo mais abundante a $25 \stackrel{\circ}{\circ}$ do que a $37^{\circ} \mathrm{C}$, sugerindo que esses genes operam na transformação dos diferentes fenótipos de Candida spp, da fase opaca (O) para a fase branca (W).

Poucos estudos analisam a expressão de Sap8, Sap9 e Sap10, já que há evidências de que a secreção dessas enzimas ocorre de forma distinta, ou seja, elas não são enzimas extracelulares. A atividade de Sap9 e Sap10 parece estar relacionada com a regulação e manutenção da integridade da superfície celular (LIAN; LU, 2007). Xu et al. (2005) demonstraram que SAP10 parece estar relacionada com a aquisição de resistência ao fluconazol, por amostras de Candida albicans.

A análise da expressão das SAPS, em candidiase vulvovaginal tem sido estudada por vários autores. Em 1999, De Bernardis et al. observaram que a deleção de genes SAP2 pode diminuir totalmente o potencial de $C$. albicans de produzir infecções vaginais, em ratas. Ao inserir cepas mutantes de SAPS1,2 e 3, os autores observaram que os mutantes de SAPS 2 foram menos virulentos que os demais. Ao reinserir o gene, a patogenicidade retornou, demonstrando a importância desse gene, para patogenicidade. A quebra dos genes SAPS 1 e 3 foi menos danosa, do que a quebra dos genes SAP2.

De acordo com Naglik et al. (2003a), a expressão de SAP1, SAP3, SAP4. SAP7 e SAP8 estão mais relacionadas com doenças na mucosa oral, enquanto as SAP1, SAP4 e SAP6-8 estão associadas com infecção vaginal. Contudo, vários estudos têm demonstrado outros resultados. Na Figura 1 há a provável expressão dos genes SAPS com os estágios de infecção.

Lian e Liu (2007) analisaram a expressão de SAP1- SAP7, através da técnica de PCR transcriptase reversa (RT), de amostras de secreção vaginal, provenientes de mulheres portadoras assintomáticas e com quadros de vulvovaginites primaria e recorrente. Neste estudo, os autores encontraram SAP2, SAP4-6 em todas as amostras; SAP7 foram predominantemente encontradas nas amostras de portadoras assintomáticas e SAP1 e SAP3 foram encontradas somente nas mulheres com quadros 
de candidiase vulvovaginal, comprovando que, a expressão de genes SAP pode ser diferente durante o processo de colonização e da produção de doença. Resultado semelhante ao obtido por Naglik et al. (2003b). Em estudo realizado com mulheres portadoras assintomáticas e sintomáticas, os autores observaram que a expressão de SAP3 foi maior em mulheres sintomáticas do que em assintomáticas, indicando que a expressão de SAP3 poderia auxiliar na infecção por Candida spp.

Figura 1: Expressão de SAPS e a função fisiológica associada a cada um dos genes

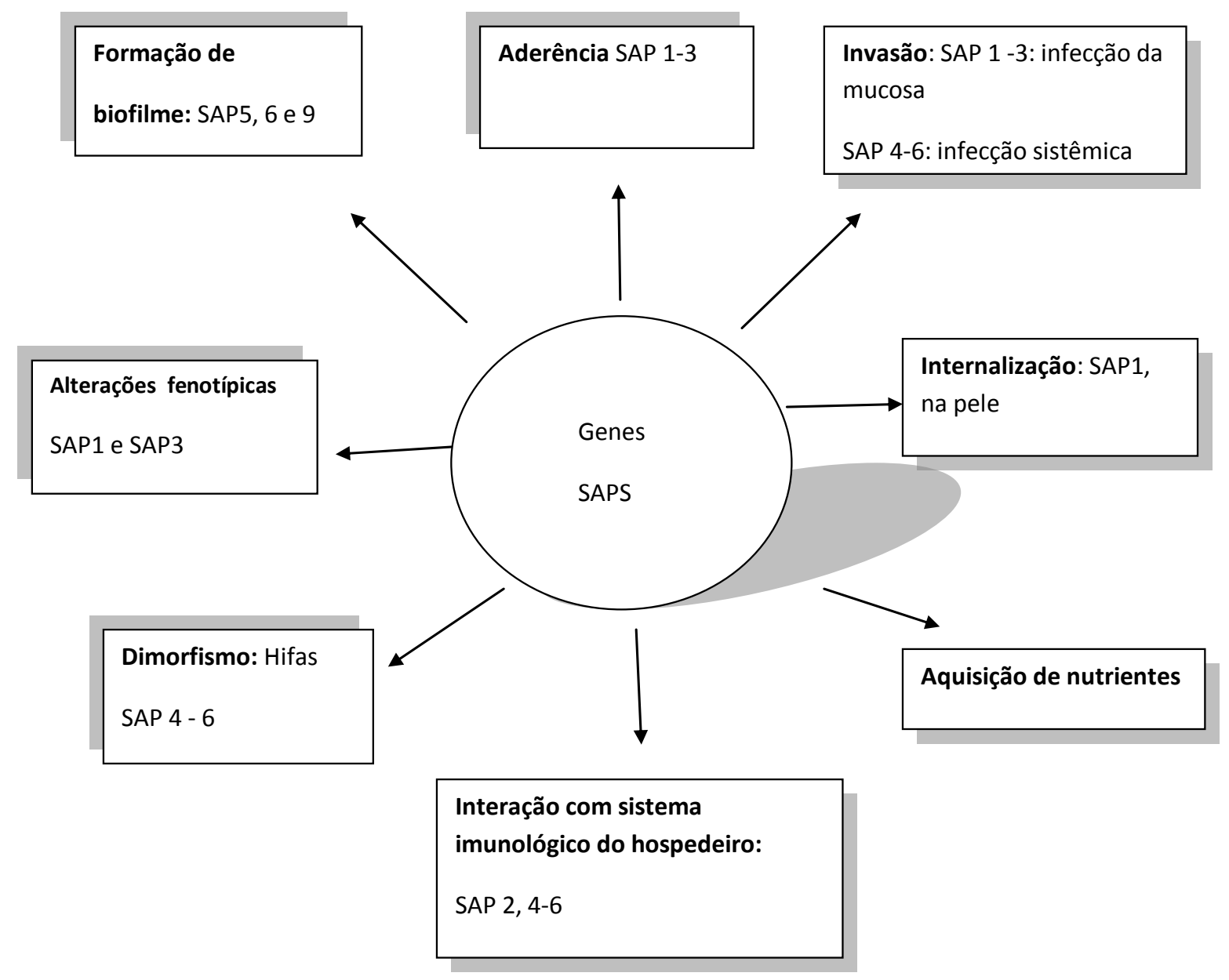

Fonte: Adaptado de Naglik et al. (2004)

Em um estudo realizado por Ishiguro et al. (1992) os autores estudaram as características sorológicas de mulheres portadoras sintomáticas e assintomáticas. Os 
autores obervaram que o padrão de ligação contra os antígenos celulares e a frequência de detecção de antígenos não foi diferente nos dois grupos. Contudo, quando os autores testaram a atividade dos anticorpos contra a Saps purificadas, a partir de meio de cultura específico, a expressão de anticorpos IgG foi maior no grupo das sintomáticas do que nas assintomáticas, comprovando que as Saps podem estimular a produção de anticorpos. No grupo das assintomáticas, 18\% expressaram anticorpos também. De acordo com os autores, esse fenômeno pode estar associado a presença de Candida spp em outros locais do corpo.

Outro grupo de enzimas hidrolíticas secretadas por Candida spp são as fosfolipases (PL) e sete genes distintos foram identificados e ligados a essa produção, sendo denominados de PLA, PLB1, PLB2, PLC1, PLC2, PLC3 e PLD1. Essas enzimas normalmente hidrolisam ligações ésteres dos fosfolipídios e, nos hospedeiros, podem auxiliar na degradação das membranas celulares, que pode levar a lise da celular. Este processo pode facilitar tanto a adesão das leveduras quanto a penetração da levedura aos tecidos (WILLIAMS; LEWIS, 2011). A expressão de fosfolipase, em meio utilizandose gema de ovo é menor em C. glabrata do que em outras espécies de Candida. Em estudo realizado por Al-Rawi (1999), com noventa e oito isolados de Candida glabrata, provenientes de secreção vaginal, não produziram essa enzima.

A pouca expressão dos genes SAPS e PL em amostras de C. glabrata ser indicativo de uma menor virulência dessa espécie. Alternativamente, as amostras de $C$. glabrata parecem expressar as proteínas denominadas de YPS (yapsin like). As YPS são proteínas de superfície primariamente identificadas em Saccharomyces cerevisae (KRYSAN et al., 2005).

\subsection{Espécies de Candida spp envolvidas na candidíase vulvovaginal}

A distribuição das leveduras do gênero Candida, identificadas em mulheres portadoras assintomáticas e sintomáticas, varia de acordo com a localização geográfica bem como, de acordo com a população estudada (ACHKAR; FRIES, 2010).

Normalmente, apenas uma espécie é encontrada em amostras de conteúdo vaginal. Contudo, aproximadamente de 2 a $5 \%$ das mulheres podem apresentar uma ou 
mais espécies, no conteúdo vaginal. Geralmente, este fato está associado ao desenvolvimento de candidiase recorrente (FAN et al., 2008).

C. albicans é a espécie mais isolada em casos de vulvovaginites por Candida, sendo isolada de $70-90 \%$ dos casos (FAN et al., 2008; PIROTTA et al., 2006). Essa espécie é a melhor estudada e, pode ser encontrada como comensal em varias partes do organismo, como no trato gastrointestinal, na mucosa oral e na mucosa vaginal. Contudo, poucos estudos relatam a presença de C. albicans no ambiente (PAULA et al., 1983). Esta aparente ausência pode estar associada a adaptações no ciclo de vida da levedura (COOPER JR., 2011).

Quando cultivada em meios de cultura próprios e, em temperaturas ótimas. C. albicans produz estruturas que permitem diferenciá-la das demais espécies, como a capacidade de produzir clamidoconídeos, na posição terminal das hifas. Outra característica importante é o estágio inicial da hifa que é diferente pois, há a ausência de constrição, na base, formando a estrutura conhecida como tubo germinativo. Em meio cromogênico, CHROMagar Candida, Candida albicans apresenta coloração verde (COOPER JR., 2011).

Em 1995, Sullivan et al. descreveram, em amostras isoladas de cavidade oral de indivíduos portadores da Síndrome da Imunodeficiência Adquirida, uma espécie de levedura com características fenotípicas bastante similares a $C$. albicans. Atualmente, alguns autores propõem a existência de testes fenotípicos que parecem permitir a diferenciação entre as duas espécies, como a termotolerância a temperatura de $45{ }^{\circ} \mathrm{C}$ e a capacidade de crescimento Sabouraud hipertônico (ALBERT et al., 2002), apresentados por C. albicans (LORETO et al., 2010; SULLIVAN 2005).

A presença de $C$. dubliniensis em secreção vaginal de mulheres sem imunodeficiência parece ser inexpressiva. Us e Cengiz (2007) coletaram amostras de mulheres gestantes e, 2,43\% apresentaram características fenotípicas de $C$. dubliniensis, porém, os autores não relatam a realização de testes genotípicos que confirmem esse dado. Na Turquia, AL-Sweich et al., em 2005, analisaram 1644 amostras de coleção de cultura, provenientes de uma maternidade, identificadas como C. albicans e, observaram que, a presença de $C$. dubliniensis nestas amostras foi de $0,2 \%$, através de análise molecular. Entre mulheres portadoras de HIV, Badiee et al. 
(2010) relataram que, das 86 amostras de Candida spp provenientes de secreção vaginal, $13,3 \%$ foram identificadas como $C$. dubliniensis, comprovando, assim, que este patógeno parece estar intimamente relacionado com a presença de HIV.

Outra espécie de grande importância médica é Candida glabrata (FAN et al., 2008; OZCAN et al., 2006). Dentre as Candida não albicans, essa é considerada de maior importância, não só em casos de candidiase vulvovaginal, como em outros quadros clínicos, como na colonização da mucosa oral e em infecções do sangue (COOPER JR., 2011).

Nas rotinas laboratoriais, a distinção de C. glabrata de outras espécies patogênicas é relativamente simples, pois, essa não produz hifas e pseudo-hifas em meio contendo ágar fubá, com Tween 80 e são observados apenas blastoconídeos pequenos. Contudo, a diferenciação dessa com $C$. famata pode depender de provas bioquímicas específicas. Em meio cromogênico, C. glabrata produz uma coloração que varia de cor de rosa claro ao magenta. Essa coloração pode ser produzida por outras espécies de Candida, fato que não permite a utilização dos meios cromogênicos como única ferramenta para a identificação dessa espécie.

Cooper Jr. (2011) chama a atenção para a dificuldade de cultivar e manter as amostras de C. glabrata em meios usualmente utilizados em laboratório, pois, para que essa manutenção seja eficaz, a levedura depende de meio enriquecido com uma fonte de colesterol exógeno, pois, as cepas utilizariam o colesterol, presente no meio de cultura, para a síntese do ergosterol, presente em sua membrana estrutural.

A taxonomia de Candida glabrata é um tanto controversa. Inicialmente, a levedura, descrita por Berlese, em 1895, foi denominada como Cryptococcus glabratus. Em 1938, Lodder e De Vries usaram o termo Torulopis glabrata e, em 1978, Yarrow e Meyer incluíram essa levedura no gênero Candida (apud MENDLING et al., 2003). Entretanto, estudos moleculares recentes, mostram que $C$. glabrata possui maior similaridade com Saccharomyces cerevisae do que com as leveduras do gênero Candida (KUO et al., 2010; MIYAZAKI et al., 2011; ROETZER, 2011).

A presença de C. glabrata no conteúdo vaginal é bastante expressiva. Mendling (1988) relata que $25 \%$ das mulheres podem ser portadoras assintomáticas dessa espécie. Essa colonização parece estar associada com a idade. Em um estudo 
realizado por Qi et al. (2005), os autores estudaram 273 jovens saudáveis, com idade inferior a 21 anos. O grupo que apresentou maior colonização por $C$. glabrata foi o de jovens com idade entre 18 e 21 anos, comprovando essa hipótese.

C. tropicalis está associada a infecções por Candida spp na corrente sanguínea, em pacientes com leucemia (MARINA et al., 1991) e com neutropenia, após um longo tempo de hospitalização (PEMAN et al., 2011). Em quadros de candidiase vulvovaginal, embora as amostras de $C$. tropicalis apresentem sensibilidade "in vitro" as drogas antifúngicas utilizadas, essa espécie está relacionada à casos de candidiase recorrente (KOTHAVADE et al., 2010).

Em isolados de secreção vaginal, C. tropicalis varia bastante. Fan et al. (2008) encontraram 0,9\% de C, tropicalis, na China; na Grécia, Grigoriou et al. (2006) há a descrição de 1,6\% do total de isolamentos; Bulmer et al. (1999), nas Filipinas relatam a presença dessa levedura em $14 \%$ dos isolados. No México, C. tropicalis foi a terceira especie mais isolada em mulheres com e sem sintomas de infecção vaginal (SANCHEZ et al., 2006).

O isolamento do complexo C. parapsilosis em amostras oriundas de secreção vaginal é significativa. Bulmer et al. (1999) encontraram a especie como a segunda causa mais frequente de candidiase vulvovaginal, com $17.8 \%$ de isolamento. Aproximadamente $20 \%$ das mulheres portadoras assintomáticas de leveduras portam C. parapsilosis. Fato esse que levaram Nyirjesy et al. (2005) a questionarem se esta presença está ou não associada a produção de sintomas, ou se a levedura estaria apenas colonizando a mucosa vaginal. Os resultados obtidos demonstraram que a presença de $C$. parapsilosis foi de $8,5 \%$ dos isolamentos realizados e, $72,5 \%$ dessas mulheres apresentaram sintomas de candidiase vulvovaginal.

A diferenciação de $C$. parapsilosis, das demais espécies de Candida spp é possível graças a produção de pseudo-hifas alongadas, na forma de "pinheiro". Contudo, o grau de formação de pseudo-hifas varia de acordo com o isolado. Em meio cromogênico, a coloração de C. parapsilosis varia de cor-de-rosa a lavanda (COOPER JR., 2011).

A fase telemórfica de C. parapsilosis não foi descrita, na literatura. Entretanto, Tavanti et al. (2005), através de análises moleculares sugeriram a criação de duas 
novas espécies: $C$. orthopsilosis e $C$. metapsilosis, que compõem o chamado complexo C. parapsilosis (GONÇALVES et al., 2009; TROFA; GÁCSER; NOSANCHUK, 2008).

Outras espécies, como C. krusei (Pichia kudriavzevil) e C. guilliermondii (Meyerozyma (Pichia guilliermndii) (COOPER JR., 2011) são leveduras em que, o isolamento, em casos de candidiase vulvovaginal varia entre 0,2 a $2 \%$. Porém, apresentam características importantes como uma menor sensibilidade "in vitro" aos antifúngicos, fato que pode contribuir para maior desenvolvimento de recorrência, ou falha terapêutica.

\subsection{Sinais e sintomas clínicos de CVV}

Candidiase, na fase aguda usualmente está associada a leucorréia, prurido, e hiperemia (MOREIRA; PAULA, 2006).

A leucorreia, ou corrimento branco ou amarelado consiste em uma mescla de células vaginais com polimorfonucleares (ZIARRUSTA, 2002). Este sintoma pode ser agravado durante o período pré-menstrual e, que é aliviado após a menstruação. Alterações de pH não são observadas durante a infecção aguda por Candida spp.

O prurido pode estar associado a reações de hipersensibilidade do hospedeiro ou a mecanismos do sistema imunológico (SOBEL, 2007) como a liberação de substancias como as prostaglandinas e bradicininas, que possuem a capacidade de induzir processos inflamatórios locais (MENDLING, 1988).

O exame clínico mostra a presença de eritema difuso ou irregular, na parede vaginal e no colo uterino e, ocasionalmente, pode-se observar, ainda, a presença de placas de leveduras, na parede vaginal e, consequente formação de erosão (MENDLING, 1988).

De acordo com Sobel (2007), os sinais e sintomas apresentados não permitem distinguir a infecção por Candida albicans das demais espécies. Contudo, Geiger at al. (1995) suportam que há padrões distintos da infecção causada por C. glabrata. A presença de leucorreia é menos abundante do que nas mulheres com $C$. albicans. Isto pode ser resultante da não formação de hifas e pseudo-hifas, por essa espécie. Além disso, percebe-se que há uma menor resposta inflamatória e menos disperemia. A 
presença de sensação de ardência é relatada em mulheres com $C$. glabrata, em substituição ao prurido provocado por $C$. albicans. A presença de eritema difuso é observada, ao exame clinico e, não há relatos da presença de placas, na parede vaginal, quando a infecção está associada a $C$. glabrata.

Porém, esses sinais e sintomas variam de acordo com o estágio da infecção e, faz-se necessário a realização de exames laboratoriais que confirmem a espécie envolvida nos quadros de candidiase vulvovaginal.

\subsection{Diagnóstico Laboratorial}

\subsubsection{Identificação Tradicional}

A maneira mais simples de coletar amostras de conteúdo vaginal é com auxílio do uso de espéculos, que permitem a avaliação de toda a parede vaginal bem como o colo uterino (MENDLING, 1988).

Em mulheres com sintomas específicos de candidiase vulvovaginal, o conteúdo vaginal pode ser examinado através do exame microscópico direto, ou o mesmo pode ser suspenso em solução salina a $0,85 \%$ Este procedimento pode auxiliar na detecção de elementos, como hifas e blastoconideos, além de permitir a exclusão de diagnostico de Trichomonas vaginalis e Gardnerella vaginalis (GONZALEZ et al., 2011). A adição de hidróxido de potássio pode melhorar a acurácia desse exame, pois facilita a visualização de hifas (SOBEL, 2007).

Contudo, cerca de $50 \%$ das mulheres com sintomas de candidiase apresentam o exame direto negativo. Esse fato pode indicar a presença de espécies que não são formadoras de hifas e pseudo-hifas, como C. glabrata (SOBEL, 1998).

A coloração do esfregaço pelo método de Gram é um teste indicado para o diagnostico de vaginose bacteriana, já que permite a visualização de estreptococos, "clue cells" (indicadoras de Gardnerella vaginalis), além de permitir a detecção de Trichomonas vaginalis. Apesar de não haver preconização para a utilização desse método para o diagnóstico de Candida spp, essa coloração mostra-se altamente eficaz em melhorar a visualização das estruturas das leveduras, inclusive, facilitando a 
detecção de blastoconideos, presentes em espécies que não filamentam, como ocorre com C. glabrata.

A não visualização de leveduras, no exame direto, requer a realização de cultura do conteúdo vaginal (MENDLING, 1988; SOBEL 2007). A cultura está indicada também para casos em que a mulher não responde ao tratamento, já que, através da cultura, é possível a identificação da levedura, em nível de espécie. Este fato facilita a conduta

terapêutica a ser adotada. É possível, ainda, a monitoração da eficácia terapêutica, já que de sete a dez dias após o termino da medicação, é possível observar se ainda restam micro-organismos viáveis (MENDLING, 1988; SOBEL, 2007).

A cultura pode ser realizada em vários meios utilizados na microbiologia, como ágar sangue ou ágar Chocolate, ou, ainda, em meios específicos para isolamento de fungos, como ágar Sabouraud dextrose ou CHROMagar Candida ® (Biomerieux, França), que por conter extratos cromogênicos, permite a detecção de mais de uma espécie em um mesmo isolado clinico (MADHAVAN et al., 2011; ODDS et al., 2003).

Após a obtenção das cepas, a realização de testes bioquímicos, como os testes de assimilação (BEIJERICK, 1889) e de fermentação de açúcares e permite a identificação das leveduras, em nível de espécie (apud KURZTMAN, 2011).

\subsubsection{Métodos moleculares de diagnóstico de CV}

O diagnóstico das infecções fúngicas é realizado, frequentemente, com base nas características morfológicas e metabólicas, o que pode requer dias ou semanas para que 0 isolamento e a identificação das espécies sejam concluídos. Com isso, o desenvolvimento de métodos de diagnósticos mais rápidos e com maior acurácia têm sido pesquisados (SANDHU et al., 1995). Vários grupos (NOBLE, 2005; RIBEIRO et al., 2005) têm desenvolvido os testes baseados nas reações em cadeia de polimerase (PCR).

O advento da biologia molecular tem providenciado muitas ferramentas para os taxonomistas de fungos. As reações de PCR e sequenciamento de genes providenciam rápida e acurada identificação de um grande número de patógenos. Novas espécies não poderiam ser descritas com base nos testes fenotípicos. 


\subsubsection{Reação em Cadeia de Polimerase (PCR) e sequenciamento}

O alvo mais frequente das pesquisas de PCR são os DNA ribossomais. Os genes de DNA ribossomal são encontrados em todos os micro-organismos e são conhecidos por acumular mutações lentas (IWEN; HINRICHS, RUPP, 2002).

A maior parte do genoma haploide de Candida spp consiste em DNA mitocondrial e DNA ribossômico (DNAr). No DNA ribossomal existe, três regiões codificadoras relativamente conservadas que incluem a região $18 \mathrm{~S}$, uma sequencia altamente conservada de $5.8 \mathrm{~S}$ e a região $28 \mathrm{~S}$.

Entre a região $5.8 \mathrm{~S}$ e a $28 \mathrm{~S}$ existem regiões de sequências variáveis denominadas de regiões Espaçadores Internos Transcritos, ou em inglês, Internal Transcribed Spaces, ITS 1 e ITS2 são regiões que permaneceram conservadas ao longo da evolução. A região ITS1 apresenta uma rápida evolução e a região ITS2 apresenta uma evolução moderadamente rápida, demonstrando baixo polimorfismo intraespecífico e alto polimorfismo interespecífico (IWEN; HINRICHS, RUPP, 2002; PINCUS; ORENGA, CHATELLIER, 2007).

Kurztzman et al. (2008) descreveram a existência de divergências extensas na região D1/D2 do DNA ribossomal que permite a diferenciação de até 500 especies de Ascomicetos. De acordo com os autores alterações de $1 \%$ dos 600 nucleotídeos presentes nessa região podem ser suficientes para distinguir as espécies e, alterações de um a três nucleotídeos é suficiente para diferenciar espécies correlacionadas ou similares.

Através das análises das regiões ITS e D1/D2 é possível a identificação de leveduras, em gênero e espécie (CHEN et al., 2000; CIARDO et al., 2006; FELL et al., 2000; LIGOURI et al., 2010); verificar se há alterações entre as espécies (IIDA et al., 2005) e ainda se, as espécies estão inter-relacionadas (KURZTMAN; ROBNETT 1997). A Figura 2 traz um desenho esquemático da região ITS. 
Figura 2: Localização das regiões ITS 1 e ITS 2

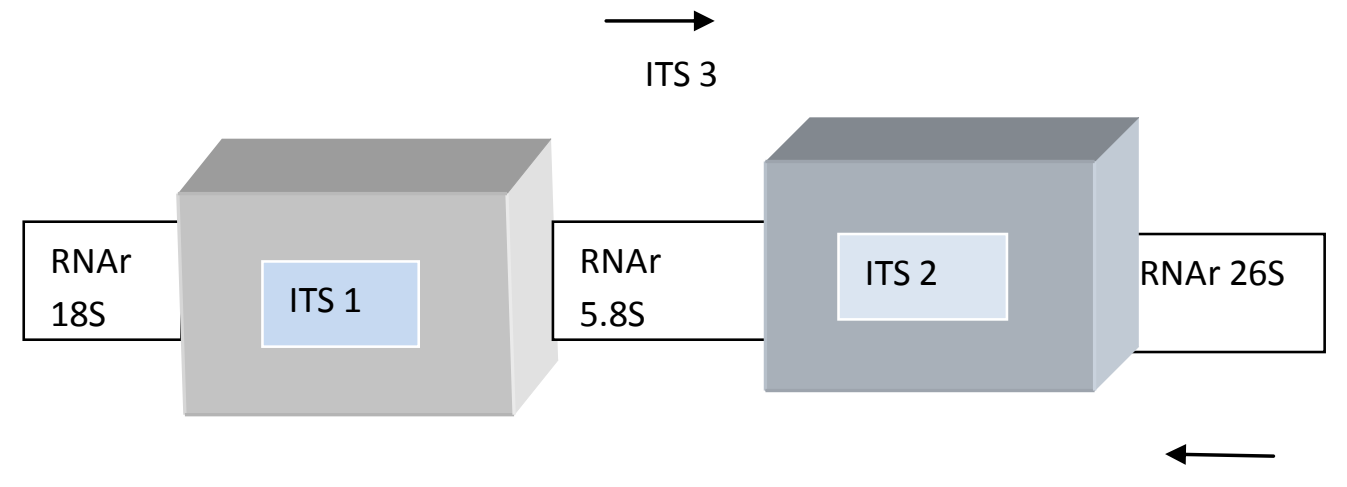

ITS 4

Fonte: PINCUS; ORENGA, CHATELLIER, 2007

Fonseca et al. (2000), através da análise da região D1/D2 identificaram uma nova espécie de Candida chamada C. tartarinovans, que possui grande aplicação biotecnológica, pois é capaz de degradar acido tartárico.

Fell et al. (2000) realizaram análise de 337 isolados de leveduras pertencentes aos Basidiomicetos ou "Basidiomycetes like" e, através da região D1/D2 foi possível a diferenciação das leveduras em "clusters". De acordo com os autores a análise da região D1/D2 permite a diferenciação da maioria das espécies. Porém, uma análise mais segura é obtida através da análise conjunta dessa região (D1/D2) com a região ITS. Opinião que também é compartilhada por Fonseca et al. (2000) e Kurtzman et al., (2007).

Com isso, vários estudos estão utilizando o sequenciamento direto das regiões ITS e D1/D2 para identificação de leveduras. A capacidade de sequenciar os ácidos nucleicos proporcionou um grande avanço nas áreas da Biologia e da Medicina, pois, possibilitou a ampliação do conhecimento da estrutura primaria dos genes e auxiliou na inferência da função das sequências já conhecidas (FLOREZ et al., 2007).

Após a realização do sequenciamento, as ferramentas de bioinformática e os bancos de dados de domínio público possibilitou um avanço na análise dos resultados. O banco de sequências mais popular existente é o Gen Bank, do NCBI. 
Através do sequenciamento da região D1/D2, Garner et al. (2010), sequenciaram 109 amostras de leveduras oriundas de amostras clinicas veterinárias e identificaram 30 espécies distintas.

Porém, de acordo com Ciardo et al. (2006), nem todas as identificações geradas pelo Gen Bank são altamente confiáveis, pois, em casos de pequenas alterações na sequencia de nucleotídeo, o banco pode entender que há uma espécie não conhecida, ou ainda, podem haver sequências que não foram depositadas no banco, gerando alguns erros de identificação.

O advento das técnicas de separação de DNA cromossomal intacto por eletroforese em eucariotos pequenos tem providenciado, nas ultimas duas décadas, meios de caracterizar arranjos de cromossomos. Estas técnicas têm fornecido novas informações fundamentais para uma organização básica sobre o genoma de muitas espécies de fungos. Essas pesquisas são baseadas na separação eletroforética de DNA não digerido ou por comparação de padrões de macro restrições obtidas pelo uso de endonucleases de restrição. A aplicação desses protocolos permitem obter espécies com padrões cada vez mais específicos (BELLOCH et al., 1997; FLOREZ, et al.,. 2007).

Em comparação com os métodos de detecção direta, que utilizam sequências universais ou espécie especificas, as técnicas de tipagem tem como objetivos identificar a mesma linhagem em isolados independentes; identificar mudanças microevolutivas em uma mesma linhagem (isolados que são altamente similares, porém, não idênticos; agrupar isolados moderadamente relacionados e, identificar isolados completamente não relacionados (BORIOLLO; HOFLING, 2004).

As espécies fúngicas apresentam cromossomos de comprimentos polimórficos que são resultantes de rearranjos cromossômicos desiguais ou de quebra de parte do cromossomo.

As sequências polimórficas podem ser avaliadas através da técnica de cariotipagem eletroforética em gel de campo pulsado (PFGE). Essa técnica permite a separação de fragmentos de DNA utilizando campo pulsado. A fim de se evitar a quebra do DNA durante a extração, as células são colocadas inteiras em blocos de agarose e a quebra dos componentes celulares é realizada com a adição de soluções tampão no bloco inicial e, são tratados com enzimas e detergentes, que removem os componentes 
celulares. Os fragmentos do DNA da levedura é, então, separado de acordo com o tamanho e, podem ser visualizados em gel corado com brometo de etídio. Através da técnica de PFGE é possível visualizar fragmentos que variam de 10 a 800 quilobases (TRTCHOVA; RADAVSKY, 2006).

Em 1988, Merz et al., analisaram dezessete isolados de C. albicans e encontraram 14 padrões distintos de bandas. Em 1989, o mesmo autor, em conjunto com Kaufmann, avaliaram o perfil cromossômico de trinta e três amostras de $C$. glabrata e, observaram que o número de bandas variava de 9 a 12, com peso de 445 a 3000 quilobases. Nesse estudo, 22 padrões distintos de bandas foram observados,

Vasquez et al. (1993) compararam o perfil cromossômico de várias espécies de Candida, através da técnica de PFGE e da análise de enzimas de restrição (REA). No PFGE, os autores encontraram 14 padrões de C. Iusitaniae; 16 de C. glabrata; 10 de $C$. tropicalis, 10 de $C$. parapsilosis e 7 de $C$. kefyr. Através da técnica de REA, os índices obtidos foram 2 de $C$. Iusitaniae, 2 de $C$. glabrata, 5 de $C$. tropicalis, 3 de $C$. parapsilosis e 1 de $C$. kefyr. Esses dados comprovam que a técnica de PFGE apresenta maior poder de discriminação dos isolados do que a REA.

Com isso, vários estudos epidemiológicos utilizam o PFGE (DE BERNARDIS et al., 1999; DOl et al., 1992; KHATAK et al., 1992; SHIN et al., 2001; 2004). A técnica apresenta a desvantagem de ser trabalhosa e, os resultados demorarem até cinco dias para serem concluídos, o que inviabiliza sua utilização em rotinas laboratoriais. Porém, sua utilização em estudos epidemiológicos é de suma importância.

\subsection{Tratamento da CVV}

O tratamento das infecções vaginais deve ser realizado de acordo com o histórico individual de cada mulher e a classificação da candidiase vulvovaginal é importante para determinar a duração do mesmo (SOBEL et al., 2004).

De acordo com Sobel (2007), o tratamento de mulheres portadoras assintomáticas é controverso, pois, as leveduras poderiam estar em equilíbrio com os demais micro-organismos presentes na microbiota vaginal e, ao inserir a utilização de um fármaco, o mesmo seria rompido. Por outro lado, a presença de leveduras, na 
mucosa vaginal, poderia ser precursora do desenvolvimento de candidiase sintomática, em período, como na gestação, em que há um aumento da secreção dos hormônios femininos, ou ainda, em casos de parto natural, no momento da passagem do bebê pelo canal vaginal pode ocorrer contaminação da mucosa oral dos recém-nascidos, predispondo-os a infecções secundárias graves como septicemias.

A conduta terapêutica a ser adotada,, nos tratamentos de quadros clínicos de candidiase vulvovaginal deve ser realizada de forma individual e, deve levar em conta o quadro clinico apresentado.

Em casos de candidiase vulvovaginal primária as mulheres podem ser tratadas com doses simples de antifúngicos, como o butoconazol, clotrimazol, miconazol, econazol ou nistatina.

Contudo, quando após o fim do tratamento ainda persistem sinais de infecção, faz-se necessário um tratamento mais prolongado, de 5 a 7 dias (SOBEL, 2007).

Os antifúngicos disponíveis para o tratamento de candidiase vulvovaginal podem estar na forma de cremes e pomadas, para uso tópico; na forma de óvulos, que devem ser utilizados como supositórios, ou como capsulas, para ser administrado por via oral. De acordo com Seidman e Skokos (2005) nos Estados Unidos, o tratamento de escolha, para casos mais simples é com tioconazol na forma de creme; com soluções que contenham $6,5 \%$ de miconazol, na forma de óvulos ou com dose única de fluconazol, por via oral.

De acordo com Sobel (2007), o uso dos antifúngicos na forma tópica é bem tolerado, contudo, algumas mulheres relatam a sensação de ardência. Porém, a taxa de cura pode variar de 80 a 90\%, em casos menos severos da doença (REEF et al., 1995).

$\mathrm{Na}$ literatura, vários trabalhos comparam a eficácia dos cremes com o uso de fluconazol, via oral.

Mendling et al. (2004) compararam a performance do clotrimazol, sob duas formas de apresentação, com a performance do fluconazol Os autores concluíram que as terapias tópicas podem ser tão eficazes quanto a dose única de fluconazol. Após 14 dias, as taxas foram de $62 \%$ e $60 \%$, respectivamente. Após oito semanas, $50 \%$ das mulheres, com histórico de candidiase recorrente relataram o reaparecimento dos sintomas, em ambos os tratamentos. 
Seidman e Skokos (2005) realizaram estudo comparativo com creme a base de butoconazol e fluconazol, via oral. Neste estudo, os autores relatam que houve o desaparecimento dos sintomas clínicos mais rapidamente, nas mulheres que fizeram uso de creme.

O tratamento da candidiase vulvovaginal recorrente é mais complicado, pois, é um quadro multifatorial e, necessita de uma atenção mais direta.

Nesses casos, faz se necessária a adoção de regimes profiláticos de antifúngicos, durante um período mais prolongado. $O$ uso do cetoconazol, por três meses (100mg/dia) e o uso de supositório a base de clotrimazol ou a prescrição de $150 \mathrm{mg}$ de fluconazol, por via oral, pelo período de três meses, são os tratamentos indicados. Contudo, o cetoconazol é pouco utilizado, devido a toxicidade (SOBEL, 2007).

Alguns autores indicam o uso de terapias alternativas para o tratamento de candidíase recorrente, como o uso de probióticos. Outro caso que merece atenção mais detalhada é quando a mulher apresenta quadros de candidiase causados por Candida não-albicans. As vulvovaginites causadas por C. glabrata não respondem ao tratamento com fluconazol. Contudo, há atividade moderada com itraconazol, terconazol, cetoconazol e itraconazol (SOBEL, 1993).

Sobel (2007) propõe que nesses casos, seja adotada a utilização de $600 \mathrm{mg}$ de ácido bórico, em cápsulas de gelatina, por 14 dias ou que sejam utilizados supositórios a base de anfotericina $B$.

Existem casos em que as mulheres não respondem a terapia apenas com ácido bórico, pode se realizar uma terapia combinada de acido bórico com uso de nistatina, na forma de cremes e uso oral de itraconazol.

\subsection{Testes de Susceptibilidade}

A sensibilidade às drogas antifúngicas varia entre as diferentes espécies de Candida. Este fato realça a importância em se identificar as espécies, bem como em se determinar as CIMs (Concentração Inibitória Mínima) dos antifúngicos para que, dessa forma, seja possível evitar o aparecimento de cepas resistentes e se realizar a conduta terapêutica adequada (ST-GERMAIN et al., 2001). 
Consequentemente, houve uma maior necessidade do desenvolvimento de métodos padronizados de susceptibilidade "in vitro", que poderiam servir como um guia para nortear a escolha terapêutica e para monitorar a eficácia da mesma (COSTA et al., 2004).

Existem vários testes que podem ser usados para a determinação da sensibilidade antifúngica, tais como: 1) Diluição em meio liquido por técnicas de macrodiluiçao e microdiluição; 2) Difusão em ágar a partir de discos e fitas com concentrações variáveis de antifúngicos.

Em 1992 foi publicado pelo Comitê Nacional de Padronização Laboratorial (NCCLS), o documento M27-P, para testes de sensibilidade "in vitro" para as leveduras (ESPINEL-INGROFF et al., 2006), principalmente para Candida spp e Cryptococcus neoformans (LINARES et al., 2004). Em 2002, foi aprovado o documento M27-A2, propondo algumas alterações ao documento M27A, publicado anteriormente (ACIKGOZ et al., 2004; ANREDRUP et al., 2001). Esse documento estabelece valores de referência para a realização dos testes de sensibilidade "in vitro" pelos métodos de macro e microdiluição em caldo e define a interpretação da concentração inibitória mínima (CIM) para avaliar a eficácia de alguns antifúngicos (DURAN et al., 2003; SANGLARD, 2002; SHÜNJl et al., 2004). E em 2008, o CLSI publicou o documento M27-A3 que inclui os valores de sensibilidade e resistência às drogas anidulafungina para os ensaios de susceptibilidade para Candida spp e Cryptococcus spp. .

Em 1997, o Comitê Europeu de Testes de Susceptibilidade (EUCAST) propôs algumas alterações ao documento do CLSI e, o Subcomitê de Testes de Susceptibilidade aos antifúngicos (AFST) desenvolveu o método que hoje é chamado de EUCAST EDef 7.1.

As diferenças entre os dois métodos estão apresentadas na Tabela 2. Diversos estudos (CLAUDINO et al., 2008; CHRYSSANTHOU; CUENCA-ESTRELLA, 2002; ESPINEL-INGROF et al., 2005; PFALLER et al., 2010; RODRIGUEZ-TUDELA et al., 2010) comparam a eficácia dos dois métodos.

Rodriguez-Tudela et al. (2007) realizaram ensaios utilizando os dois métodos e, concluíram que os resultados foram bastante similares, após 24 horas de incubação e, na análise de regressão linear, o EUCAST/AFST mostrou valores de Concentração 
Inibitória Mínima inferior ao do método do CLSIM27S3. Cuesta et al. (2010), avaliaram o ponto de corte dos métodos para o fluconazol e, encontraram resultados bastante similares entre os dois.

Tabela 2: Diferenças entre os métodos CLSI M27S3 e o Eucast EDef7.1

\begin{tabular}{|c|c|c|c|c|c|c|}
\hline Método & $\begin{array}{l}\text { Adição } \\
\text { de } \\
\text { glicose } \\
(\%)\end{array}$ & $\begin{array}{l}\text { Tipo de } \\
\text { Placa }\end{array}$ & $\begin{array}{l}\text { Inóculo } \\
\text { (UFC/mL) }\end{array}$ & $\begin{array}{l}\text { Tempo de } \\
\text { incubação } \\
\text { (h) }\end{array}$ & Leitura & $\begin{array}{c}\text { Ponto de } \\
\text { corte }\end{array}$ \\
\hline $\begin{array}{l}\text { CLSI } \\
\text { M27S3 }\end{array}$ & 0.2 & $\begin{array}{l}\text { Fundo } \\
\text { arredondado }\end{array}$ & $\begin{array}{l}0.5 \times 10^{3}- \\
2,5 \times 10^{3}\end{array}$ & 48 & Visual & $\begin{array}{l}\text { Inibição } \\
\text { substancial } \\
\text { do } \\
\text { crescimento }\end{array}$ \\
\hline $\begin{array}{l}\text { EUCAST } \\
\text { EDef7.1 }\end{array}$ & 2 & Fundo Plano & $\begin{array}{l}0.5 \times 10^{3} \\
2.5 \times 10^{3}\end{array}$ & 24 & Espectrofotômetro & $\begin{array}{l}\text { Inibição de } \\
50 \% \text { do } \\
\text { crescimento, } \\
\text { em relação } \\
\text { ao controle }\end{array}$ \\
\hline
\end{tabular}

UFC: Unidade formadora de colônia.

Fonte: Tabela adaptada do artigo de Rodriguez-Tudela et al., (2007)

Não obstante, para a realização dos testes de macro e microdiluição, problemas como a padronização do inóculo, meio de cultura, $\mathrm{pH}$, período e temperatura de incubação e inibição parcial do crescimento dificultam a reprodutibilidade dos ensaios. Em laboratórios de microbiologia onde há um grande volume de amostras, esses testes são muito trabalhosos e de leitura demorada (ANREDRUP et al., 2001).

Com isto, as pesquisas para o desenvolvimento de testes comerciais para a verificação da suscetibilidade vêm aumentando. Um dos métodos comerciais mais utilizados é o "Etest" (AB BIODISK, Solna, Suíça), que consiste em fita plástica 
impregnada com gradiente de diferentes concentrações das drogas antifúngicas, que são depositadas na superfície do ágar (SHÜNJl et al., 2004).

De acordo com o fabricante os meios recomendados para a realização dos ensaios são ágar RPMI com $2 \%$ de glicose mais tampão MOPS; ágar casitone; ágar Casitone e ágar Müler Hinton. Contudo, um estudo realizado por Tortorado et al. (1998) com os três meios de cultura mostrou que os resultados obtidos com a utilização do meio ágar Müller Hinton teve menor concordância do que o obtido com os dois outros meios, em relação ao método do CLSI.

Diversos estudos, como os realizados por Colombo et al. (1995), Dias et al. (2006) e Silva et al. (2005), Espinel-Ingroff (2006) comprovam que há uma boa correlação entre o "“Etest”" e os métodos de micro e macrodiluição, preconizados pelo CLSI. Em 2010, Espinel-Ingroff et al., observaram que, o desempenho do "Etest" pode ser superior para detectar a resistência de algumas espécies, como $C$. albicans, $C$. glabrata, C. tropicalis e C. krusei, com concordância de 87.9 a $100 \%$, em relação ao CLSI M27S3.

Essa pesquisa é uma contribuição ao estudo de candidíase vulvovaginal levandose em consideração os aspectos abordados, os questionamentos e hipóteses ainda existentes a respeito da intrigante relação existente entre parasita e hospedeiro. 
2 objetívos 


\subsection{Objetivos Gerais}

Este estudo teve como objetivos comparar os perfis fenotípicos e genotípicos, a resistência aos antifúngicos e a produção de enzimas de amostras de leveduras isoladas do fluido vaginal de três grupos de mulheres: assintomáticas, com quadro de: candidiase primária (CVV) e com candidiase recorrente (CVVR) .

\section{a. Hipóteses a serem testadas}

a) Verificar se as amostras de leveduras apresentam diferentes perfis fenotípicos e genotípicos, que as distinguem de mulheres assintomáticas das mulheres com infecções (CVV e CVVR);

b) Verificar se existem diferenças no perfil cromossômico das leveduras isoladas do conteúdo vaginal das mulheres pertencentes aos três grupos amostrais, pela técnica de cariotipagem em campo pulsado (PFGE);

c) Determinar a correlação entre a identificação tradicional e a identificação molecular, através da técnica de sequenciamento;

d) Verificar se existe diferença entre a resistência aos antifúngicos por três métodos, o "gold standard " (CLSI), Eucast e "Etest" ;

e) Pesquisar se há correlação entre os resultados obtidos nos três grupos de mulheres analisadas (assintomáticas de leveduras, com candidiase primária e com candididíase recorrente). 
3 MATERIAL E MÉTODOS 


\subsection{Mulheres que participaram do estudo}

Foram realizadas coletas de mulheres atendidas no Serviço de Dermatologia Sanitária do Centro de Saúde "Geraldo de Paula Souza" da Faculdade de Saúde Pública da Universidade de São Paulo, pelo Prof. Dr. Luis Jorge Fagundes. A determinação do número de mulheres foi realizada de acordo com cálculos estatísticos do Pesquisador do Instituto de Matemática da USP (IME) Rogério Pinheiro.

Com aprovação do Comitê de Ética e Pesquisa das Instituições envolvidas, após assinarem o Termo de Consentimento (Anexo $\mathrm{C}$ ) as coletas foram realizadas.

Foram excluídas do estudo mulheres que fizeram uso de drogas antifúngicas no prazo inferior a 15 dias antes da coleta e de gestantes.

Foram incluídas no estudo mulheres não grávidas; que faziam ou não uso de contraceptivos hormonais e as que utilizavam ou não DIU (Dispositivo Intrauterino).

\subsubsection{Coleta do material vaginal}

Através do "Protocolo de avaliação clínica" (Anexo A) obtiveram-se dados como uso de medicação e a presença de sinais e sintomas clínicos característicos de infecção vaginal.

Com auxílio de espéculo sem lubrificante foram realizadas três coletas, com "swabs" estéreis e alginatados (Cefar). O material coletado foi utilizado para a realização de exame direto. Realizou-se também a coloração de esfregaço pelo método de Gram, a fim de se avaliar a presença ou não de células leveduriformes ou pseudo-hifas; o material colhido foi levado imediatamente ao laboratório de Leveduras Patogênicas, do Instituto de Ciências Biomédicas da USP, para ser processado.

\subsection{Definições dos grupos}

Foram consideradas positivas as mulheres que apresentavam a presença de leveduras no esfregaço corado pelo método de Gram, associada com cultura positiva para leveduras. Essas foram divididas em três grupos: 
a. portadoras assintomáticas: mulheres que apresentaram presença de leveduras na cultura da secreção vaginal e que não tinham manifestado sintomas clínicos de CVV (corrimento vaginal, prurido e hiperemia), até o momento da coleta;

b. com candididíase (CVV): mulheres que apresentaram cultura positiva para leveduras e que tiveram episódios esporádicos de candidíase durante o período de um ano;

c. candidiase recorrente (CVVR): mulheres que apresentaram mais de quatro episódios de Candida spp por um período de um ano (SOBEL, 2007).

\section{3 isolamento e condições de crescimento}

As leveduras isoladas foram identificadas de acordo com os métodos preconizados por Kurztman e Fell (1988) procedendo-se de acordo com o protocolo preconizado no laboratório de Leveduras Patogênicas, do Departamento de Microbiologia, da Universidade de São Paulo (Anexo B).

A diferenciação fenotípica de Trichosporon spp foi realizada de acordo com Hoog et al. (2000).

\subsubsection{Diferenciação entre C. albicans e C. dubliniensis}

A diferenciação entre $C$. albicans e $C$. dubliniensis foi feita de acordo com critério proposto por Coleman et al. (1997) baseado nas características fenotípicas. Para a realização dos ensaios foram utilizadas as amostras padrões ATCC 64548 (C. albicans) e ATCC777 (C. dubliniensis).

\subsubsection{Diferenciação em "CHROMagar Candida®"}

As amostras de C. albicans foram cultivadas em ágar Saboraud dextrose (Difco, USA, Detroit), por 24 horas. Após a incubação, os isolados foram repicados em CHROMagar Candida (Biomerieux, Paris, France) e incubadas por até 86 horas a 30 ${ }^{\circ} \mathrm{C}$, visando-se a obtenção de colônias de coloração característica. Nessas condições, 
as amostras de $C$. dubliniensis apresentam coloração verde escura, enquanto que $C$. albicans apresentam coloração verde clara.

\subsubsection{Crescimento a $45^{\circ} \mathrm{C}$}

As amostras de Candida albicans foram repicadas em ágar Sabouraud dextrose (Difco, USA, Detroit), com cloranfenicol $(100 \mu \mathrm{g} / \mathrm{mL})$ e incubadas a $37^{\circ} \mathrm{C}$, por $24 \mathrm{~h}$. Depois foram transferidas para tubos pequenos com ágar Saboraud dextrose e incubadas a $45^{\circ} \mathrm{C}$. Amostras de $C$. dubliniensis não crescem nessa temperatura.

\subsubsection{Caldo Sabouraud hipertônico}

O caldo de Sabouraud hipertônico foi realizado de acordo com a descrição de Alves et al. (2002). A partir de cultivo de 24 horas, em ágar Saboraud dextrose das amostras de Candida albicans foram realizadas suspensões, em tubos de ensaio contendo $3 \mathrm{~mL}$ de solução salina a $0.85 \%$. A suspensão foi homogeneizada em aparelho 'Vortex' e a densidade de células foi ajustada em espectrofotômetro (Spectrum/USA) em comprimento de onda de $530 \mathrm{~nm}$, tendo como base a transmitância da escala 0,5 de McFarland. Alíquotas de $20 \mu \mathrm{L}$ de cada suspensão foram adicionados a tubos contendo $1 \mathrm{~mL}$ de caldo Sabouraud estéril suplementada com $6,5 \%$ de cloreto de sódio (Merck/USA) e, em seguida, incubadas por $96 \mathrm{~h}$. As culturas foram então examinadas visualmente para a detecção de crescimento fúngico, em intervalos de 24 h. O resultado positivo do teste foi definido como a ausência de crescimento da colônia visível no tubo de ensaio após 96 h de incubação. Neste caso, $C$. albicans, mas não $C$. dubliniensis é capaz de crescer em excesso de $\mathrm{NaCl}$.

\subsubsection{Diferenciação molecular das amostras sugestivas de C. dubliniensis}

Amostras que apresentaram caracteristicas fisiológicas sugestivas de $C$. dubliniensis, nos itens 3.4.1.1; 3.4.1.2 e 3.4.1.3 foram submetidas a sequenciamento da região ITS1 e ITS4 para confirmar a identificação, conforme descrito no Item 3.4. 
3.3.2 Diferenciação das amostras de leveduras pertencentes ao complexo $C$. parapsilosis strictu sensu

As amostras identificadas como C. parapsilosis, nas provas fisiológicas foram submetidas a diferenciação molecular, através de Reação de Polimerase em Cadeia PCR) e, sequenciamento da região ITS1 e ITS4, conforme descrito no Item 3.4.

3.3.3 Identificação das leveduras que não foram identificadas pelas provas fisiológicas: Candida spp

Os isolados que não foram identificados, pelos métoos tradicionais de identificação foram submetidos ao sequenciamento da região ITS1 e ITS4, conforme descrito no item 3.4.

\subsection{Reação de Polimerase em Cadeia (PCR) e Sequenciamento}

\subsubsection{Extração de DNA das Leveduras}

Após a identificação fenotípica dos isolados, uma colônia pura e isolada de cada amostra cultivada em meio CHROMagar foi repicada em meio liquido YPD (Yeast Extract Peptone Dextrose (Difco/ USA, Detroit) e incubada por 24 h a $30 \stackrel{\circ}{\circ}$ sob agitação (200rpm).

A cultura obtida foi empregada para a extração do DNA total das leveduras, conforme protocolo comercial PrepMan ${ }^{\mathrm{TM}}$ Ultra Sample Preparation reagent Quick Reference Card "Applied Biosystems/ USA". Um mililitro da suspensão foi submetido a centrifugação por 3 minutos, a $16.000 \times$ g. Posteriormente, descartou-se 0 sobrenadante e o "pellet" ressuspenso em 100uL do reagente "PrepMan" e submetido a agitação por 20 segundos no vórtex. A reação foi, então, incubada em banho maria a $100 \stackrel{\circ}{C}$ por 10 minutos e, em seguida deixa em temperatura ambiente por 2 minutos.

Posteriormente, a amostra foi centrifugada por 3 minutos a $16000 \mathrm{xg}$ e $90 \mathrm{uL}$ do sobrenadante contendo o DNA foi transferido para um novo tubo e armazenado em freezer a $-20 \stackrel{\circ}{ } \mathrm{C}$. 
O DNA extraído foi quantificado por dosagem espectrofotométrica à razão de O.D. $260 \mathrm{~nm} / 280 \mathrm{~nm}$ no aparelho "NanoVue Plus" (General Electric/USA). O grau de pureza do DNA foi avaliado em relação à proteína $(260 \mathrm{~nm} / 280 \mathrm{~nm})$ e o grau de pureza do DNA em relação ao sal $(260 \mathrm{~nm} / 230 \mathrm{~nm})$. O valor ótimo esperado é entre 1.8 - 2.0.

Após a determinação das concentrações foram preparadas amostras de DNA na concentração de $50 \mathrm{ng} / \mathrm{uL}$, que foram estocadas e preservadas a $-20 \stackrel{\circ}{ } \mathrm{C}$.

\subsubsection{Amplificação}

A amplificação foi realizada utilizando "“primers"” que amplificam fragmentos da região ITS do DNA ribossomal (DNAr). Os "“"primers"” das regiões ITS1/ITS4 foram:

"forward" 5' TCCGTAGGTGAACCTGCGG3" e "reverse" 5' TCCTCCGCTTATGATATGC3'. Como padrão foi utilizada a cepa ATCC 64548 (C. albicans)

Para a reação de PCR foram preparados 25uL de solução contendo 23uL de "TaqMan Universal PCR Master Mix" (Applied Biosystems/USA) e 2uL de DNA a 50ng/uL. As condições de amplificação foram: denaturação inicial de 5 minutos à 95 ${ }^{\circ} \mathrm{C}$, seguida de 35 ciclos de 1 minuto a $56 \stackrel{\circ}{\mathrm{C}}$, 2 minutos a $72 \stackrel{\circ}{\mathrm{C}}$, com extensão final de 10 minutos a $71^{\circ} \mathrm{C}$, em Termociclador (Veriti 96-well Thermal - Applied Biosystems).

Para a corrida eletroforética, 5uL do DNA foi adicionado a 2 ul de corante (EZ Vision, Ambresco), que permite a visualização da corrida e dispensa o uso de solução de brometo de etídio. Os amplicons foram submetidos a eletroforese em gel de agarose (Invitrogen Life Technologies/ USA) a 1\% diluído em tampão TAE (Tris-Acido acéticoEDTA) 1x. Todas as análises incluíram um marcador de peso molecular de 500 a 10,000 pb (MW MARKER, Ambresco).

Após a eletroforese a visualização das bandas de DNA foi realizada com auxilio de aparelho fotodocumentador (Bio Rad/USA), sob iluminação de luz ultravioleta. 


\subsubsection{Sequenciamento}

Além dos "primers" ITS1/ITS4, para a reação de sequenciamento foram utilizados os "primers" V9G "forward" (5'TTACGTCCCTGTCCTTTGTA3') e LS "reverse" (5'GCATTCCCAAACAACTCGACT3').

A amplificação foi realizada, em placas com 96 pocinhos, adicionando-se 100ng do DNA purificado, $9 \mu \mathrm{L}$ de cada primer "forward" e "reverse"” em poços separados, $2 \mu \mathrm{L}$ do "ABI Prism® Big Dye ${ }^{\circledR}$ Terminator v3.1" (Applied Biosystems/ USA), $4 \mu \mathrm{L}$ de tampão Tris-HCL $200 \mathrm{mM}$ e $5 \mathrm{mM}$ de $\mathrm{MgCl}_{2}$.

As condições de amplificação foram: uma etapa de anelamento, de 20 minutos a $95 \stackrel{\circ}{ } \mathrm{C}$, seguida de 25 ciclos de $50 \stackrel{\circ}{\circ}$, por 15 minutos, $60 \stackrel{\circ}{\circ}$, por 1 minuto. Após essa etapa, as placas foram vedadas e armazenadas em freezer a $-20 \stackrel{\circ}{\circ}$.

Após a denaturação a $94{ }^{\circ} \mathrm{C}$ por 4 minutos, as sequências foram determinadas pelo aparelho "DYEnamic ${ }^{\mathrm{TM}}$ ET Terminator Cycle Sequencing" (Applied Biosystem/ USA), pertencente ao Laboratório de Retrovirologia da Universidade Federal de São Paulo (Unifesp).

As sequências foram alinhadas com auxilio do "software Sequencher 4.1.4" e, comparadas com as sequências disponíveis no "GenBank", com auxílio do programa BLAST.

\subsection{Determinação dos fatores relacionados a virulência}

\subsubsection{Pesquisa de Proteínase (Sap `S)}

A pesquisa de proteinase em placa foi realizada de acordo com o método descrito por Price et al. (1982).

O meio para a realização do teste é composto por uma solução de $0,2 \%$ de albumina bovina (BSA, fração V, Sigma), $5 \mu \mathrm{L}$ de vitamina B (Roche) e "Yeast Carbon Base" (Difco, Detroid/ USA). O pH foi ajustado em 5,0, esterilizado por filtração, e adicionados a $2 \%$ de ágar autoclavado. 
As placas contendo quatro inóculos de diferentes cultivos foram incubadas a $37{ }^{\circ} \mathrm{C}$ por 4 dias. Como controle positivo foi utilizado a cepa de C. albicans (ICB12A). A presença da enzima foi observada pela formação do halo de degradação ao redor da colônia da levedura e a atividade enzimática medida (Pz) segundo Price et al.(1982) através da razão entre o diâmetro da colônia (dc) e o diâmetro da colônia mais zona de degradação (dd). Os resultados foram analisados conforme padrão descrito na Tabela 3.

Tabela 3: Atividade enzimática (proteinase e fosfolipase) conforme o PZ e o código

\begin{tabular}{ccc}
\hline $\mathbf{P Z}$ & Atividade enzimática & Código \\
\hline 1 & Negativa & 1 \\
$>0,64<1$ & Positiva & 2 \\
0,64 & Fortemente Positiva & 3 \\
\hline $\begin{array}{l}\text { PZ: Diâmetro da colônia/ diâmetro do halo de precipitação ou degradação } \\
\text { Fonte: Price et al.(1982) }\end{array}$
\end{tabular}
Fonte: Price et al.(1982)

\subsubsection{Pesquisa da Fosfolipase}

A atividade de fosfolipase será realizada de acordo com os métodos propostos por Ruchel et al. (1982), com utilização de ágar Sabouraud modificado, acrescido de $2 \%$ de gema de ovo. As placas contendo quatro inóculos de diferentes cultivos foram incubadas a $37{ }^{\circ} \mathrm{C}$ por 4 dias. A cepa de C. albicans (ICB12A) foi utilizada como controle positivo.

A presença da enzima foi observada pela formação do halo de precipitação ao redor da colônia da levedura e a atividade enzimática medida $(\mathrm{Pz})$ segundo Price et al. (1982) através da razão entre o diâmetro da colônia (dc) e o diâmetro da colônia mais zona de degradação (dd). Os resultados foram analisados conforme padrão descrito na Tabela 3. 


\subsection{Determinação dos Perfis de Sensibilidade e de Resistência "in vitro" às Drogas Antifúngicas}

\subsection{1 "Etest"}

A pesquisa de sensibilidade "in vitro" em difusão em meio sólido foi realizada através do "Etest".

Para as drogas anfotericina B, fluconazol, caspofungina, itraconazol, voriconazol, cetoconazol foram realizados ensaios de sensibilidade pela metodologia do "Etest".

O "Etest" foi preparado de acordo com as instruções do fabricante (AB Biodisk, Solna, Suécia). O meio utilizado foi o RPMI 1640 (Sigma/ USA) tamponado com ácido morfopropileno sulfônico (MOPS) 1,65 M, pH 7,2, com 2\% glicose (Probac $®$ ). Uma solução de $3 \%$ de ágar bacteriológico (Difco/ USA) autoclavada foi acrescentada ao meio RPMI e distribuídas em placas.

A partir de cultivo de 24 horas, em ágar Saboraud dextrose (Difco/ USA) das amostras de Candida spp, tendo como controle padrão as amostras de C. krusei (ATCC 6258) e C. parapsilosis ATCC (22019), foram realizadas suspensões, em tubos de ensaio contendo $3 \mathrm{~mL}$ de solução salina a $0,85 \%$. A suspensão foi homogeneizada em aparelho 'vórtex' por quinze minutos e a densidade de células foi ajustada em espectrofotômetro, em comprimento de onda de $530 \mathrm{~nm}$, tendo como base a transmitância da escala 0,5 de McFarland.

A suspensão foi semeada em placas de Petri, com auxílio de "swabs" estéreis (Cefar). Após 15 minutos as fitas de "Etest" foram colocadas na superfície do ágar e as placas incubadas a $37^{\circ} \mathrm{C}$ por 24 horas.

Após a incubação foram realizadas as leituras da CIM, através do ponto de intersecção entre a fita e a zona de inibição de crescimento da levedura.

A interpretação dos resultados foi realizada com base nos valores de CIM preconizados pelo documento M27A2 (2002) e M27S3 (2008), descritos pelo CLSI (Tabela 4).

Esse critério acima não estipula valores para o cetoconazol que é considerada uma droga fungistática. Apenas indica a maioria dos valores são encontrados entre 0,03 e $16 \mu \mathrm{g} / \mathrm{mL}$ (Cetoconazol) para isolados clínicos. 


\subsubsection{Microdiluição}

Os ensaios de microdiluição (EUCAST EDef 7.1 e CLSI M27S3) foram realizados nas amostras que apresentaram sensibilidade dose dependente ou intermediária e para as amostras resistentes, nos ensaios de difusão em ágar, para os seguintes antifúngicos: anfotericina $B$, fluconazol e itraconazol que são os antifúngicos mais utilizados para o tratamento de quadros de candidiase vulvovaginal.

Tabela 04 Interpretação do comportamento de cepas de Candida spp frente à concentração dos antifúngicos $(\mu \mathrm{g} / \mathrm{mL})$, segundo documentos CLSI M27A2 e M27S3

\begin{tabular}{lcccc}
\hline Caspofungina & $\leq 2$ & $\mathrm{~S} D D$ & $\mathrm{R}$ & $\mathrm{NS}$ \\
Fluconazol & $\leq 8$ & - & & $>2$ \\
Itraconazol & $\leq 0,25$ & $0.25-$ & $\geq 64$ & \\
& & 0.5 & & \\
Voriconazol & $\leq 1$ & 2 & $\geq 4$ & \\
Anfotericina & $<2$ & & $\geq 2$ (sugere) & \\
B & & & & \\
\hline
\end{tabular}

S: sensível; SDD: sensibilidade dose dependente; R: resistente; NS: não Fonte: Documentos CLSI M27-A2 e M27S3

sensível

\subsubsection{CLSI M27S3}

Os ensaios de microdiluição foram realizados em microplacas estéreis descartáveis, com 96 pocinhos, em formato de "U".

As drogas Fluconazol e Itraconazol foram obtidas diretamente de seus fabricantes, Pfizer $(12.800 \mu \mathrm{g} / \mathrm{mL})$ e Jansem $(1.600 \mu \mathrm{g} / \mathrm{mL})$, respectivamente. A anfotericina $B(1.600 \mu \mathrm{g} / \mathrm{mL})$ foi obtida da Sigma (USA).

A solução estoque de Fluconazol foi preparada, em água. As soluções estoque de Itraconazol e de Anfotericina B foram preparadas em Dimetil Sulfóxido (DMSO, Merck, EUA), por serem insolúveis em água. A partir das soluções padrões foram realizadas 10 diluições seriadas, com volume de $100 \mu \mathrm{L}$, duplamente concentradas (2x).

Após a realização das diluições, as placas foram cobertas com filme plástico e armazenadas em freezer a $-70 \stackrel{\circ}{ } \mathrm{C}$, por até seis meses. 
O meio utilizado foi o RPMI-1640 em caldo com tampão MOPS (ácido 3[Nmorfolino] propanossulfônico) $0,165 \mathrm{~mol} / \mathrm{L}$ (Sigma/USA), com L-glutamina, pH $7.0 \mathrm{com}$ indicador vermelho de fenol), suplementados com $0,2 \%$ de glicose, de acordo com o documento CLSI M27S3.

A partir de repiques de $24 \mathrm{~h}$ foram preparadas suspensões dos isolados em salina $0,145 \mathrm{~mol} / \mathrm{L}$ de $\mathrm{NaCl}$, estéril padronizadas de acordo com a escala 0,5 de McFarland (bioMérieux/ França), aproximadamente 1-5 × $10^{6}$ células $/ \mathrm{mL}$. Estas suspensões foram agitadas em vórtex durante 15 segundos e conferida a densidade celular entre os inóculos, por espectrofotômetro, com comprimento de onda de $530 \mathrm{~nm}$.

A partir desse inoculo foram realizadas diluições de 1:50 seguida de outra de 1:20 em meio de cultura RPMI 1640. Após as diluições foram adicionados $100 \mu \mathrm{L}$ do inóculo em cada orifício da placa de microdiluição, na concentração de $1 \times 10^{3}$ a $5 \times 10^{3}$ UFC/mL, de acordo com recomendações do documento CLSI M27S3.

Após repique de $24 \mathrm{~h}$, em meio de ágar Sabouraud Dextrose foram preparados suspensões dos isolados em salina $0,145 \mathrm{~mol} / \mathrm{L}$ de $\mathrm{NaCl}$, estéril padronizadas de acordo com a escala 0,5 de McFarland (bioMérieux/ França), aproximadamente 1-5 $\mathrm{x}$ $10^{6}$ células $/ \mathrm{mL}$, agitadas em vórtex durante 15 segundos e conferida a densidade celular entre os inóculos, por espectrofotômetro, com comprimento de onda de $530 \mathrm{~nm}$. O volume final em cada orifício da placa foi de $200 \mu \mathrm{L}$.

Em todas as placas foram utilizados um controle positivo e um negativo. As cepas ATCC 22019 (C. parapsilosis) e ATCC 6258 (C. krusei) foram utilizadas como controles positivos, conforme recomendações do documento CLSI M27S3.

Após a inoculação, as placas foram tampadas e incubadas a $37^{\circ} \mathrm{C}$, por 24 horas.

A leitura dos testes foi realizada de acordo com o documento do CLSI M27S3. Para as drogas fungistáticas, como itraconazol e fluconazol, a Concentração Inibitória Mínima (CIM) foi definida como a menor concentração de droga capaz de inibir 50\% do crescimento. Para a anfotericina B, o CIM foi definido como a menor concentração da droga que inibe $100 \%$ do crescimento da levedura. 


\subsubsection{EUCAST EDef 7.1}

Esse método de microdiluição preconizado pelo EUCAST (European Committee on Antibiotic Susceptibility Testing) é semelhante ao método proposto pelo CLSI. As diferenças estão na concentração de glicose (2\%) que é suplementado ao meio RPMI.

Outra diferença está na diluição da amostra, que deve ser de 1:10, em meio RPMI 1640 com $2 \%$ de glicose. As concentrações de células inoculadas nas placas resultam em uma concentração de $0,5 \times 10^{5}$ a $2,5 \times 10^{5}$ células $/ \mathrm{mL}$.

A leitura é realizada por espectrofotômetro, após 24 h e 48 h. E, o valor de CIM para a anfotericina B é de $90 \%$ do crescimento de levedura.

\subsection{Cariotipagem através da técnica Eletroforese em Campo Pulsado (Pfge)}

\subsubsection{Extração de DNA}

A técnica de eletroforese em campo pulsado (PFGE) foi realizada utilizando o aparelho CHEF MAPPER II (Bio Rad/ USA), segundo protocolo de Branchini et al. (1994), com modificações.

As amostras de Candida spp foram repicadas em CHROMagar Candida, incubada a $37 \stackrel{\circ}{\circ}$, por $48 \mathrm{~h}$. Em seguida, a colônia isolada foi repicada em ágar Sabouraud dextrose (Difco/USA) e incubada a $35{ }^{\circ} \mathrm{C}$ por $24 \mathrm{~h}$. Cerca de $300 \mu \mathrm{L}$ de células foram transferidas em microtubos tipo "Eppendorff" $(1,5 \mathrm{~mL})$ contendo a $600 \mu \mathrm{L}$ de EDTA (Sigma/USA) para lavagem das células. Os tubos foram centrifugados a 3000rpm sob refrigeração a $4 \stackrel{\circ}{ } \mathrm{C}$, por 15 minutos.

Esse procedimento foi repetido por mais duas vezes. Após a última lavagem foram adicionados $300 \mu \mathrm{L}$ de EDTA $(50 \mathrm{mM}, \mathrm{pH} 8,0)$ e o precipitado foi homogeneizado, em vórtex.

A esta suspensão de células foi adicionado $160 \mu \mathrm{L}$ da enzima Lyticase (Invitrogen) (1250 U/mL dissolvida em glicerol 50\% (v/v)-0,01M NaPO 4 pH 7,5 ([Sigma]) e a mistura foi incubada a $37{ }^{\circ} \mathrm{C}$ por $40 \mathrm{~min}$. Após esse período foram acrescentadas a esta solução $400 \mu \mathrm{L}$ de agarose low- melt (Bio Rad/ USA) a 0,8\% dissolvida em $50 \mathrm{mM}$ 
de EDTA, $\mathrm{pH} 8,0$, fundida e mantida liquefeita a $50^{\circ} \mathrm{C}$. A mistura (células/agarose) foi homogeneizada suavemente e colocada rapidamente nos moldes. $O$ conjunto foi mantido sob refrigeração a $4{ }^{\circ} \mathrm{C}$ por um período mínimo de 20 minutos.

Em seguida, os blocos foram removidos dos moldes e colocados em microtubos contendo $3 \mathrm{~mL}$ de tampão NET (Tris $1 \mathrm{M}$ [pH 7,5], EDTA 0,5 M [PH 8,0], lauroylsarcosine $1 \%$ e proteinase $\quad \mathrm{K} \quad(1 \mathrm{mg} / \mathrm{mL} ; 20 \mathrm{U} / \mathrm{mg})$ (Invitrogen Life Technologies/USA) e incubados a $50{ }^{\circ} \mathrm{C}$ por $16 \mathrm{~h}$. Após a incubação os blocos foram lavados 3 vezes com $2 \mathrm{~mL}$ de EDTA ( $50 \mathrm{mM} \mathrm{pH} 8,0)$ por $30 \mathrm{~min}$, sob agitação, a $25^{\circ} \mathrm{C}$. Uma quarta lavagem foi realizada e os blocos foram mantidos a $25{ }^{\circ} \mathrm{C}$ durante $16 \mathrm{~h}$.

Após esse período foram realizadas mais duas lavagens finais antes da realização da PFGE.

\subsubsection{Corrida Eletroforética}

Os blocos de agarose, das amostras e do peso molecular (Saccharomyces cerevisae, de 225 a 2.200kb (Bio Rad/USA) foram fixados nos pentes de corrida, com a própria agarose. O pente foi, então, posicionado no molde para gel do sistema Chef Mapper (Bio Rad/USA) e, então, agarose liquefeita, a 0,8\% foi adicionada. Após a solidificação da agarose, o pente foi retirado.

A corrida foi realizada em $2,5 \mathrm{~L}$ de tampão TAE a $0,5 \%$ a $14 \stackrel{\circ}{\circ}$. As condições de corrida foram: bloco 1, com pulso inicial e final de $120 \mathrm{~s}$; voltagem de $3.5 \mathrm{~V} / \mathrm{cm}$, ângulo de $106^{\circ}$, por $24 \mathrm{~h}$; bloco 2: pulso inicial e final de 240 seg.; voltagem de $3.5 \mathrm{~V} / \mathrm{cm}$, ângulo de $106 \stackrel{\circ}{\circ}$, por 36 h. O tampão de corrida foi substituído a cada $24 \mathrm{~h}$ de corrida, visando manter as condições de corrente continua.

Após a corrida, o gel foi corado em solução de brometo de etídio (Sigma/USA) durante 15 minutos e descorado com água destilada por 30 minutos. A documentação fotográfica foi realizada com auxilio do sistema de fotodocumentação de géis e transluminador "Quantum-ST4-1000" (Vilber Lourmat, França).

A análise do peso das bandas cromossômicas foi realizada com auxílio do "Software Quantum Capt" (Vilber Lourmat, França). 
Os padrões de macrorrestrições e a construção do dendograma foram comparados através do "software Bionumerics" (Versão 6.5, Austin, TX). Os isolados foram classificados como genotipicamente distintos quando o padrão de similaridade de bandas foi menor que $90 \%$ (Chen et al.,. 2005).

\subsection{Análise Estatística}

Para as variáveis dicotômicas, utilizou-se o teste de exato de Fischer e para as contínuas, o teste de Mann-Whitney. Para avaliar as tendências foi utilizado o teste Quiquadrado. Considerou-se significativo um valor de $p<0.05$. A probabilidade de ocorrência de alterações clínicas foi realizada através do calculo de valor preditivo positivo e negativo. A análise estatística foi realizada com auxilio do Software Bioedit (versão 7.1.3); Probabilites (versão 1.0).

Para a análise comparativa dos perfis de restrição obtidos utilizou-se o programa informático Bionumerics (Applied-Maths, Sint-Martens-Latem, Bélgica). Utilizando o coeficiente de Dice, com posições de otimização 1,0 e de tolerância de 1,5, respectivamente, construiu-se um dendograma pelo método UPGMA e considerou-se que as estirpes pertenciam ao mesmo clone de PFGE se tinham uma semelhança igual ou superior a $80 \%$, como anteriormente descrito. Para a análise comparativa dos perfis de restrição obtidos utilizou-se o programa informático Bionumerics (Applied-Maths, Sint-Martens-Latem, Bélgica). Utilizando o coeficiente de Dice, com posições de utilização 1,0 e de tolerância de 1,5, respectivamente, construiu-se um dendograma pelo método UPGMA e considerou-se que as estirpes pertenciam ao mesmo clone de PFGE se tinham uma semelhança igual ou superior a $80 \%$, como anteriormente descrito. 
4 RESULTADOS 


\subsection{Mulheres que participaram do estudo}

Este estudo foi do tipo corte transversal, no período de novembro de 2008 a maio de 2010. Foram realizadas coletas de conteúdo vaginal de 258 mulheres com e sem queixas de desconforto vaginal, com idade média de 33 anos (mediana 30; desvio padrão (DP) 10,5).

\subsubsection{Coleta de material vaginal}

Do material do conteúdo vaginal coletado foram realizados o exame direto, a coloração de Gram e a cultura. Os resultados estão descritos nos itens a seguir.

\subsubsection{Coloração do esfregaço pelo método de Gram e cultura}

Consideraram-se positivas as mulheres que apresentavam a presença de leveduras no esfregaço corado pelo método de Gram, associada com cultura positiva para leveduras. Através da coloração de Gram, a presença de estruturas leveduriformes foi observada em $68.6 \%$ do material analisado.

De acordo com a Tabela 5, a coloração do esfregaço pelo Gram apresentou $75.2 \%$ de sensibilidade para o diagnóstico de Candida spp. Das 268 amostras realizadas, $62.8 \%(162 / 258)$ apresentaram cultura positiva para leveduras. 
Tabela 5: Desempenho da coloração do esfregaço pelo método de Gram, em relação á cultura, para a confirmação do diagnóstico de Candida.

\begin{tabular}{c|c}
\hline Valores & $\%$ \\
\hline Sensibilidade & 75.12 \\
\hline Especificidade & 54.84 \\
\hline Valor preditivo positivo & 64.56 \\
\hline Valor preditivo negativo & 68.00 \\
\hline Falso negativo & 23.80 \\
\hline Falso positivo & 45.76 \\
\hline$p$ & 0.5194 \\
\hline
\end{tabular}

$P$ : probabilidade

Fonte: Moreira (2012)

A Tabela 6 mostra que a cultura apresenta $82 \%$ de sensibilidade, para a confirmação do diagnóstico de candidiase vulvovaginal em relação à coloração de Gram.

Tabela 6: Avaliação da cultura, em relação a coloração do esfregaço pelo Gram, para diagnóstico de candidiase vulvovaginal

\begin{tabular}{l|l|l|l}
\hline & $\begin{array}{c}\text { Sinais clínicos } \\
\text { positivos }\end{array}$ & $\begin{array}{c}\text { Sinais clínicos } \\
\text { negativos }\end{array}$ & \multicolumn{1}{|c}{ Total } \\
\hline Cultura positiva & 107 & 55 & 162 \\
\hline $\begin{array}{l}\text { Cultura } \\
\text { negativa }\end{array}$ & 51 & 45 & 96 \\
\hline
\end{tabular}

Sensibilidade: $68 \%$

Especificidade: $45 \%$

Valor Preditivo Positivo: 67\%

Valor Preditivo Negativo: $47 \%$

Fonte: Moreira (2012) 
Das $158(62 \%)$ mulheres que apresentavam queixa de desconforto vaginal (prurido ou leucorréia), 67\% (107/158) apresentaram cultura positiva para leveduras, $24,5 \%(38 / 158)$ apresentavam vaginose bacteriana e, $8,5 \%$ vaginose inespecífica.

\subsection{Definições de grupos amostrais}

As 162 mulheres que apresentaram cultura positiva para leveduras foram classificadas em três grupos amostrais, sendo que $34 \%$ foram consideradas assintomáticas, 34\% com candidiase primária e 32\% com candidiase de recorrência.

Uma grande heterogeneidade em relação a idade foi observada nos três grupos estudados (Figura 3) .0 grupo das mulheres portadoras assintomáticas foi o que apresentou maior diferença entre as idades $(p<0.001)$. A Figura 3 mostra a variação da idade das mulheres que participaram do estudo, por grupo amostral.

Figura 3: Variação de Idade, por grupo amostral

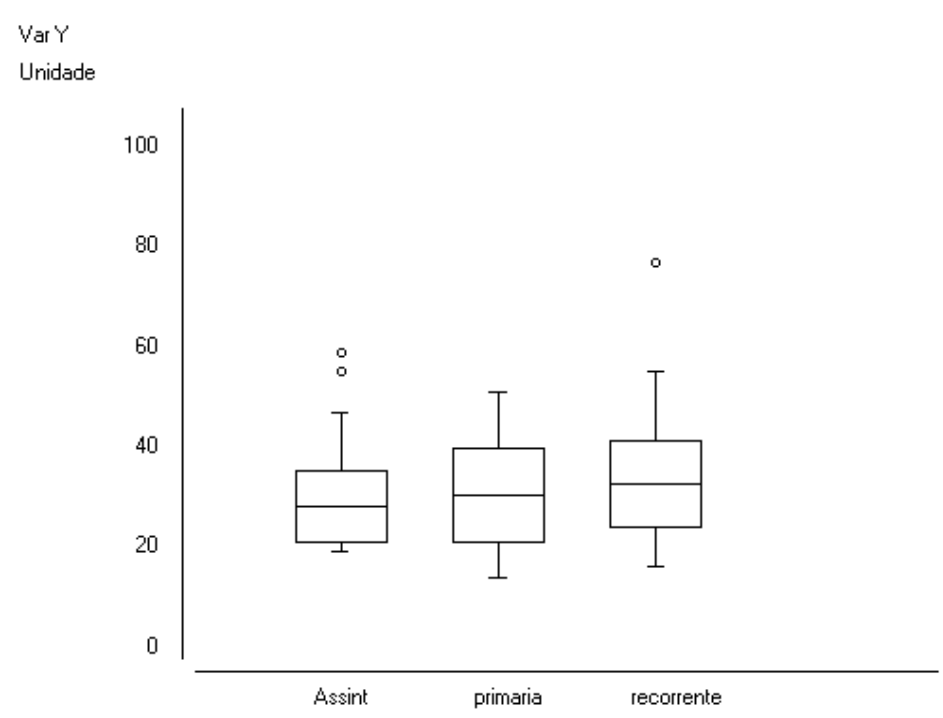

Assint: proveniente de mulheres portadoras assintomáticas.

Fonte: Moreira (2012) 


\subsection{Identificação morfológica dos isolados de Candida spp}

\subsubsection{Características Fenotípicas}

Foram realizadas análises da morfologia das colônias, em meio CHROMagar Candida e em ágar Sabouraud dextrose. Em meio Cromogênico, as amostras apresentaram coloração verde, sugestivo de $C$. albicans ou $C$. dubliniensis; azul, sugestivo de $C$. tropicalis, magenta, sugestivo de $C$. krusei e roxa, sugestivo de Candida spp. Em ágar Sabouraud todas as espécies apresentam colorações que variam do branco ao creme.

\subsubsection{Identificação de Trichosporon spp}

Através da identificação fenotípica das quatro amostras de Trichosporon spp, realizada por De Hoog et al. (2000) três isolados foram de T. asahii e um de T. inkin.

Figura 4: Cultivo de C. albicans em CHROmagar

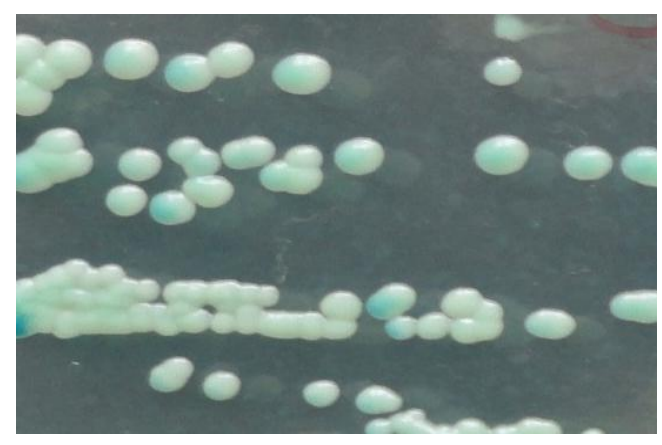

Fonte: Moreira (2012) 
Figura 5: Cultivo de $C$. dubliniensis em CHROmagar

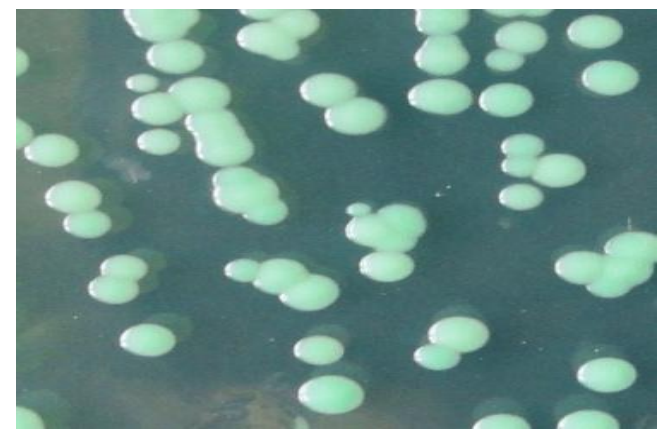

Fonte: Moreira (2012)

Figura 6: Cultivo de $C$. tropicalis em CHROmagar

Fonte: Moreira (2012)

Figura 7: Cultivo de $C$. parapsilosis em CHROmagar

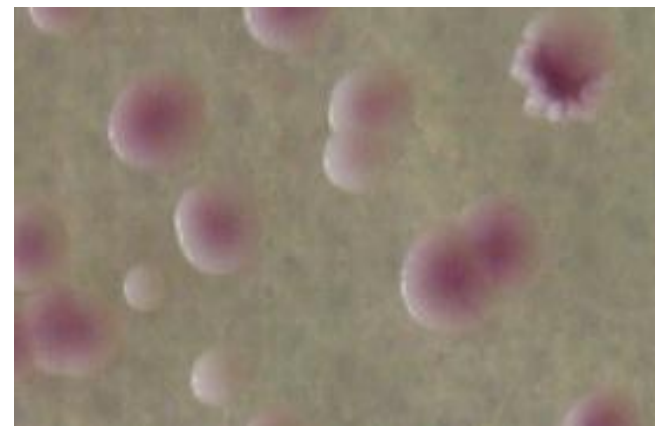

Fonte: Moreira (2012) 
Figura 8: Cultivo de C. glabrata em CHROmagar

Fonte: Moreira (2012)

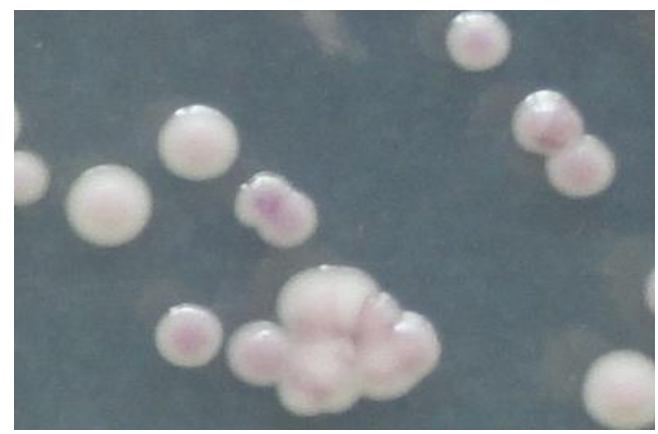

Figura 9: Cultivo de Candida albicans em ágar Sabouraud dextrose

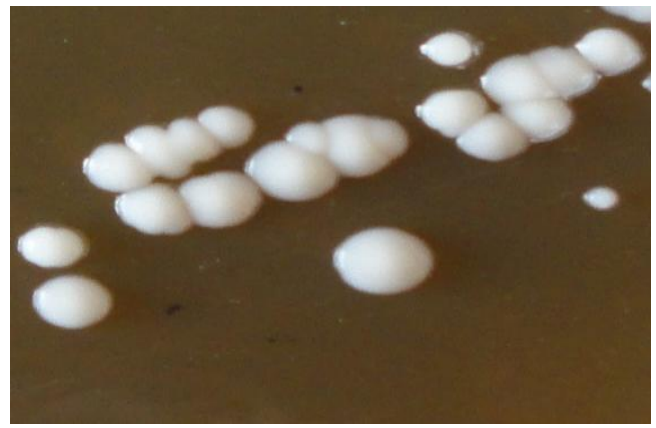

Fonte: Moreira (2012)

Figura 10: Cultura de Rhodotorula spp em ágar Sabouraud dextrose

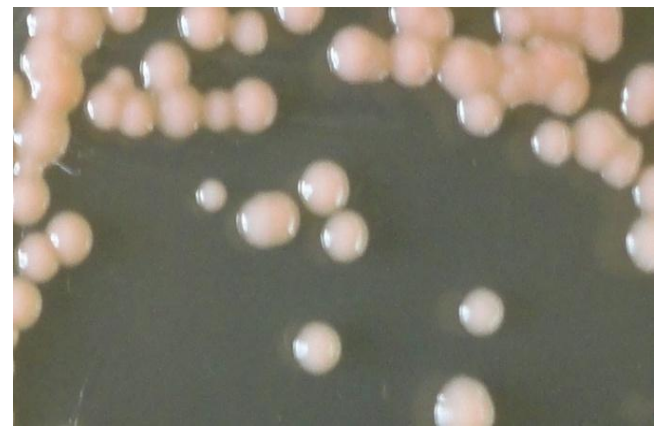

Fonte: Moreira (2012) 
Figura 11: Microcultivo em lâmina de $C$. albicans

Fonte: Moreira (2012)

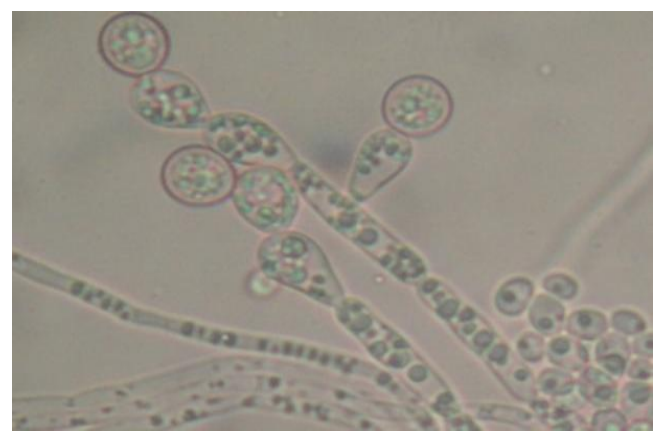

Figura 12: Microcultivo em lâmina de $C$. haemuulonii

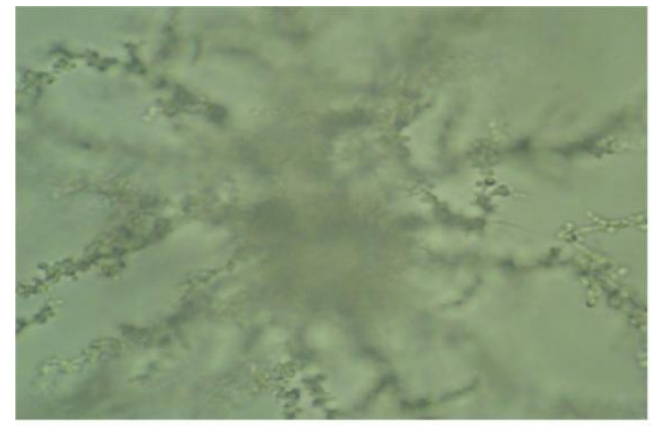

Fonte: Moreira (2012)

Figura 13: Microcultivo em lâmina de $C$. glabrata

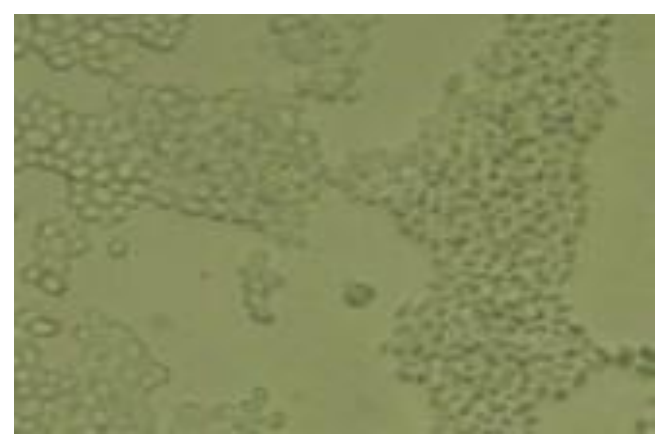

Fonte: Moreira (2012) 
Figura 14: Microcultivo em lâmina de C. parapsilosis

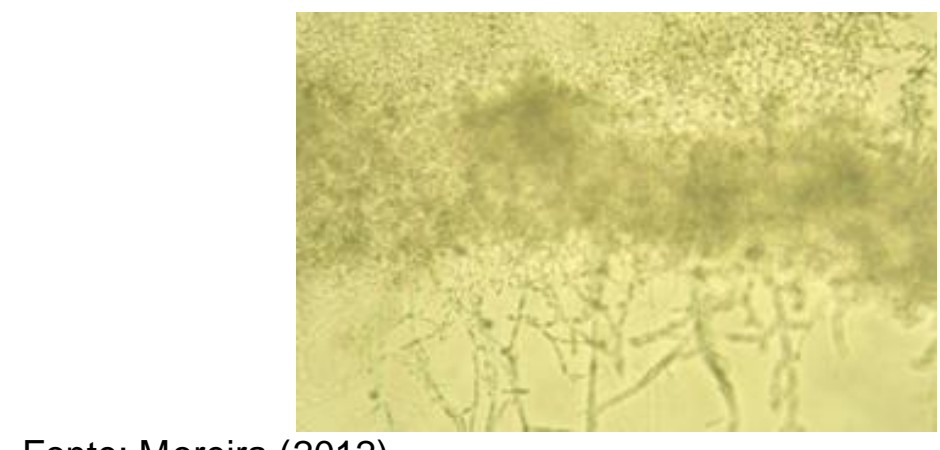

Fonte: Moreira (2012)

Figura 15: Microcultivo em lâmina de $C$. tropicalis

Fonte: Moreira (2012)

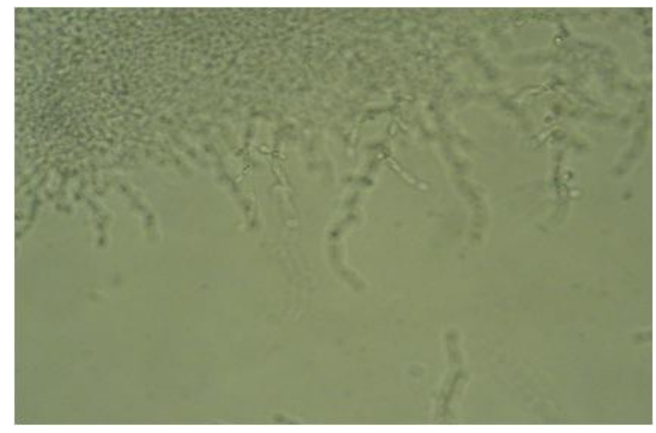

Na Tabela 7 foi realizada a comparação do desempenho do meio CHROMagar Candida para a identificação presuntiva das leveduras.

O meio cromogênico CHROMagar Candida apresentou alta especificidade para o diagnóstico presuntivo de Candida spp, a sensibilidade foi alta para $C$. albicans e $C$. krusei, porém, foi baixa para o diagnóstico de $C$. glabrata, quando comparada com os métodos tradicionais. 
Tabela 7: Relação de concordância entre os métodos convencionais e CHROMagar de para a confirmação da espécie de levedura

\begin{tabular}{llrrr}
\hline Identificação Tradicional & CHROMagar & concordância & Sensibilida de & Especificida de \\
\hline C. albicans (84) & C. albicans (74) & $88.90 \%$ & $88 \%$ & $94.50 \%$ \\
C. tropicalis (12) & C. tropicalis (8) & $66.70 \%$ & $53.30 \%$ & $97.20 \%$ \\
C. krusei (2) & C. krusei (2) & $100 \%$ & $100 \%$ & $100 \%$ \\
C. glabrata (26) & C. glabrata (45) * & & $39.13 \%$ & $91.90 \%$ \\
\hline
\end{tabular}

*Coloração: magenta

Fonte: Moreira (2012)

\subsubsection{Características Fisiológicas}

O microcultivo em lâmina foi realizado em ágar fubá, acrescido de Tween 80, que permite a identificação de hifas/ pseudo-hifas e a presença de clamidoconídeos (característicos de C. albicans e C. dubliniensis). As Figuras de 4 a 10 mostram as características microscópicas apresentadas por diferentes espécies de leveduras.

As Figuras 11 a 15 mostram as diferenças entre a micromorfologia dos isolados identificados como Candida spp.

Após a realização do microcultivo foram realizadas provas fisiológicas.

Através dos testes bioquímicos 4/160 amostras foram identificadas como Candida spp por apresentar as características descritas na Tabela 8.

Nessas amostras foram realizados sequenciamento com a finalidade de se tentar identificá-las.

\subsubsection{Diferenciação de C. albicans e C. dubliniensis}

Os principais testes utilizados na rotina laboratorial para diferenciação entre $C$. albicans e C. dubiniensis são: cor de crescimento em meio cromogênico (Figuras 4 a 8); teste de termotolerância e crescimento em meio hipertônico.

No presente estudo, 14 das 82 amostras identificadas como C. albicans apresentaram características que sugeriam a presença de $C$. dubliniensis, conforme Tabela 9. 


\subsubsection{Complexo C. parapsilosis strictu sensu}

O complexo C. parapsilosis strictu sensu engloba três espécies que apresentam perfil bioquímico similar. Na Tabela 10 estão vinte e quatro amostras que foram identificadas como C. parapsilosis, pelos métodos tradicionais. Os resultados do PCR e do sequenciamento estão descritos no Item 4.4. 
Tabela 8: Perfil fisiológico de amostras identificadas como Candida spp não classificadas pelos métodos de identificação tradicional

\begin{tabular}{|c|c|c|c|c|c|}
\hline ID & & 675 & 697 & 734 & 1017 \\
\hline Cromogênico & & roxo & roxo & bege & roxo \\
\hline \multirow[t]{13}{*}{ Assimilação } & Pep & Pos & Pos & Pos & Pos \\
\hline & $\mathrm{KNO}^{3}$ & $\mathrm{Neg}$ & Neg & $\mathrm{Neg}$ & $\mathrm{Neg}$ \\
\hline & Gli & Pos & Pos & Pos & Pos \\
\hline & Ino & Neg & Neg & Neg & $\mathrm{Neg}$ \\
\hline & Lac & Neg & Neg & Neg & Neg \\
\hline & Dul & Pos & Neg & Pos & $\mathrm{Neg}$ \\
\hline & Mal & Pos & Pos & Pos & Pos \\
\hline & Raf & Pos & Pos & Pos & Neg \\
\hline & Cel & $\mathrm{Neg}$ & Neg & Neg & Neg \\
\hline & Mel & $\mathrm{Neg}$ & Neg & Neg & Neg \\
\hline & Trea & Pos & Pos & Pos & Pos \\
\hline & Xil & Pos & Pos & Neg & Pos \\
\hline & Melz & Pos & Pos & Pos & Pos \\
\hline \multirow[t]{6}{*}{ Fermentação } & Gli & Pos & Pos & Pos & Pos \\
\hline & Lac & Neg & Neg & Neg & Neg \\
\hline & Mal & $\mathrm{Neg}$ & Neg & Pos & Pos \\
\hline & Sac & Neg & Neg & Pos & Pos \\
\hline & Raf & $\mathrm{Neg}$ & Neg & Pos & Pos \\
\hline & Trea & Neg & Neg & Pos & Pos \\
\hline \multirow[t]{4}{*}{ Crescimento } & Citrato & Pos & Pos & Pos & Pos \\
\hline & Ciclohex & Pos & Neg & Pos & $\mathrm{Neg}$ \\
\hline & $37^{\circ} \mathrm{C}$ & Pos & Pos & Pos & Pos \\
\hline & $45^{\circ} \mathrm{C}$ & $\mathrm{Neg}$ & Neg & Pos & Neg \\
\hline
\end{tabular}

Espécie Candida spp Candida spp Candida spp Candida spp

ID: identificação; Pep: peptona; KNO3: nitrato de potássio; Gli: glicose; Ino: inositol; sac: sacarose; Lac: lactose; Dul: dulcitol; Mal: maltose; Raf: rafinose; Cel: celobiose; Mel: melibiose; Trea: trealose; Xil: xilose; Melz: melizitose; Ciclohex: ciclohexemida; Pos: positivo; Neg: negativo

Fonte: Moreira (2012) 
Tabela 9: Características fenotípicas semelhantes de C. dubliniensis

\begin{tabular}{cccc}
\hline Amostra & Cromogênico & $\mathbf{4 5}^{\circ} \mathbf{C}$ & Hipertônico \\
\hline D673 & verde & negativo & negativo \\
D697 & verde & positivo & negativo \\
D810 & verde & positivo & negativo \\
D897 & verde & positivo & negativo \\
D931 & verde & negativo & negativo \\
D940 & verde & positivo & negativo \\
D954 & verde & positivo & negativo \\
D965 & verde & negativo & negativo \\
D973 & verde & negativo & negativo \\
D981 & verde & positivo & negativo \\
D1026 & verde & positivo & negativo \\
D1041 & verde & positivo & negativo \\
D1063 & verde & positivo & negativo \\
D1082 & verde & positivo & negativo \\
\hline
\end{tabular}

Fonte: Moreira (2012)

Essas amostras foram, então, selecionadas para a confirmação molecular de $C$. dubliniensis. Os resultados do PCR e do sequenciamento estão descritos no Item 4.4. 
Tabela 10: Identificação de C. parapsilosis através de provas fisiológicas e características apresentadas em meio cromogênico

\begin{tabular}{ccc}
\hline ID & Cromogênico & Espécie \\
\hline 671 & azul & C. parapsilosis \\
674 & roxa & C. parapsilosis \\
$680 a$ & roxa & C. parapsilosis \\
681 & rosa & C. parapsilosis \\
682 & roxa & C. parapsilosis \\
687 & roxa & C. parapsilosis \\
689 & branca & C. parapsilosis \\
699 & roxa & C. parapsilosis \\
703 & roxa & C. parapsilosis \\
710 & roxa & C. parapsilosis \\
742 & n.c & C. parapsilosis \\
745 & azul & C. parapsilosis \\
750 & roxa & C. parapsilosis \\
751 & n.c & C. parapsilosis \\
756 & roxa & C. parapsilosis \\
772 & roxa & C. parapsilosis \\
778 & roxa & C. parapsilosis \\
834 & roxa & C. parapsilosis \\
874 & azul & C. parapsilosis \\
936 & roxa & C. parapsilosis \\
945 & n.c & C. parapsilosis \\
1039 & roxa & C. parapsilosis \\
1043 & n.c & C. parapsilosis \\
1048 & branca & C. parapsilosis \\
\hline.$n a 0$ & aprentou crescimento; 680 \\
\hline
\end{tabular}

ID: identificação; n.c: não apresentou crescimento; 680ª̣: duas amostras de uma mesma mulher

Fonte: Moreira (2012)

Nessas amostras também realizou-se o PCR da região ITS 1 e ITS 4, e o sequencimento das regiões ITS1/ITS4 e D1/D2. Esses resultados estão descritos no Item 4.4 . 


\subsection{PCR e Sequenciamento das Candida spp Selecionadas para os Estudos Moleculares}

Quarenta e um isolados foram selecionados para realização das reações de PCR e sequenciamento, da região ITS 1 e 4. Sendo, C. dubliniensis (14), Candida spp (4), C. parapsilosis (23).

4.4.1 Reação em Cadeia da Polimerase (PCR)

A extração de DNA das leveduras foi realizada conforme descrito no item 3.5, em material e métodos. O DNA foi quantificado e diluído e, 40ng foi utilizado para a reação de PCR.

4.4.2 Amplificação da Região ITS pela Reação em Cadeia por Polimerase (PCR)

A Figura 16 mostra as bandas de amplificação de DNA da região ITS das leveduras. 
Figura 16: Bandas exibidas por Candida spp em gel de agarose

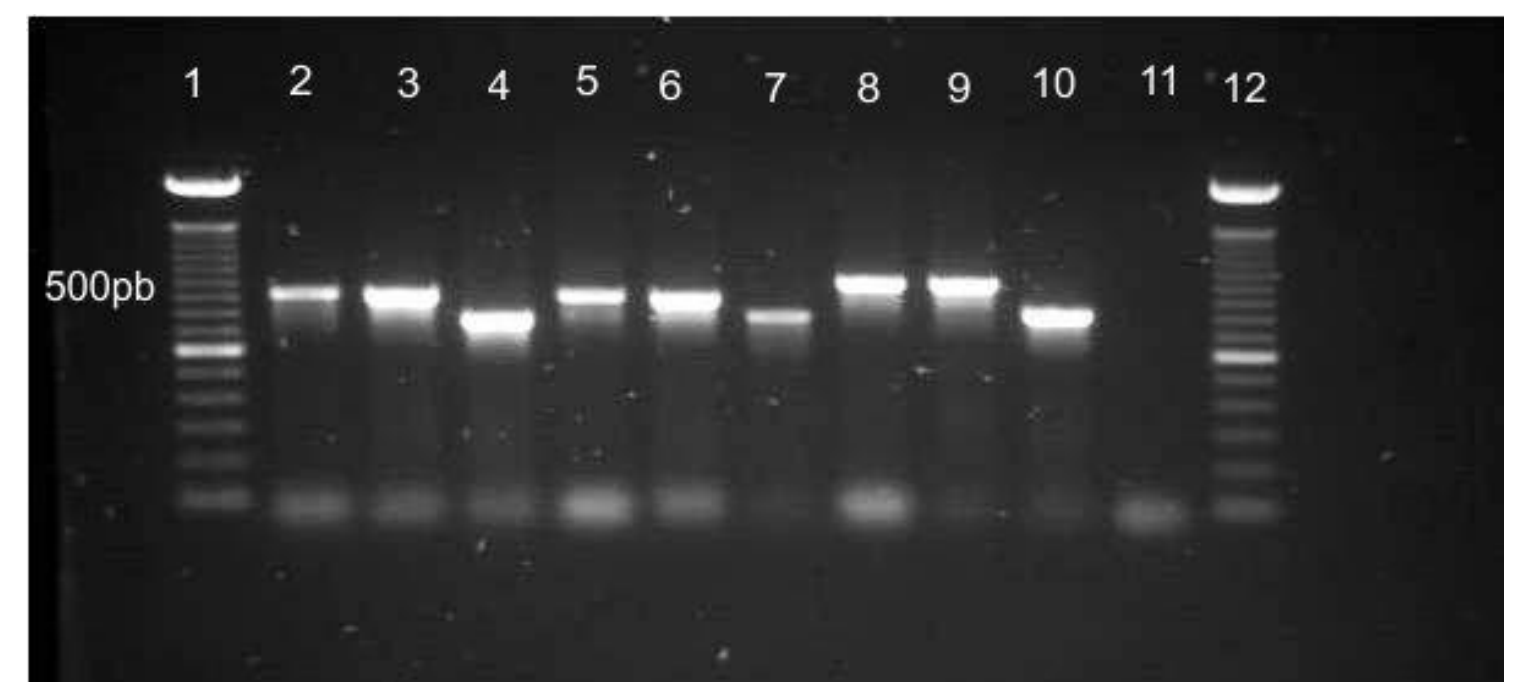

Eletroforese em gel de agarose a $1 \%$ dos produtos de PCR da região ITS1 e ITS4 das diferentes leveduras. Gel A: 1 e 12. Marcador $1 \mathrm{~Kb}$ plus DNA Ladder 2. ATCC C. albicans 3. Amostra 1082- C. albicans 4. Amostra 1017 - C. parapsilosis; 5. Amostra C. metapsilosis; 6. Cepa ATCC de C. orthopsilosis; 7: Amostra 734- C. haemulonii; 8. Amostra 804- C. guilliermondii; 9. Amostra de Pichia anomala; 10. Amostra de Candida pararugosa; 11. Controle negativo; 12. Marcador 1Kb plus DNA "Ladder" Fonte: Moreira (2012)

Observa-se que os fragmentos de DNA obtidos na PCR utilizando os oligonucleotídeos iniciadores para amplificar a região ITS variou de 350 a 650 pares de bases $(\mathrm{pb})$ sugerindo que há diferentes espécies entre os isolados.

\subsection{Sequenciamento dos Produtos da PCR}

Os produtos da PCR foram sequenciados, e as sequências obtidas foram analisadas com os programas "Sequencer 4.1.4" e foram analisadas no BLAST, que realiza a comparação entre as sequências obtidas com aquelas depositadas no GenBank e fornece dados quanto à homologia entre elas.

A Figura 16 e a Tabela 13 mostram os resultados das análises das sequências obtidas. Estão descritos os organismos com os quais foi encontrada homologia na região do respectivo número de acesso, o "score" e o valor de "E". 
O "score" indica o quanto o alinhamento foi satisfatório. Quanto maior for o valor de "score", melhor o alinhamento. Em termos gerais, o "score" é calculado a partir de uma formula que considera o alinhamento de resíduos semelhantes ou idênticos, bem como, eventuais lacunas introduzidas ao alinhar as sequências.

O valor de E é um parâmetro que descreve a similaridade, ao acaso, entre as sequências. Ele é inversamente proporcional ao valor de "“score"”. Por exemplo, um valor de e igual a 1 pode significar que em um banco de dados de determinado tamanho espera-se encontrar alguma homologia com "score" similar simplesmente ao acaso. Isso significa que quanto menor o valor de $\mathrm{E}$, ou mais próximo ao zero, maior a similaridade. Os resultados obtidos no sequenciamento estão descritos na Tabela 11.

Todos os isolados que apresentaram características fenotípicas de $C$. dubliniensis foram identificados como $C$. albicans, no sequenciamento. Dentre os isolados de $C$. parapsilosis, dois foram identificados como C. metapsilosis. Vale ressaltar que é não há relatos dessa espécie, em secreção vaginal, no Brasil. As quatro amostras identificadas como Candida spp, nos testes bioquímicos foram identificadas como C. haemulonii pelo sequencimento.

\subsection{Identificação das leveduras}

Após o sequenciamento, as identificações das 162 amostras estão descritas na Figura 17. 
Tabela 11: Resultado do sequenciamento das amostras selecionadas

\begin{tabular}{|c|c|c|c|c|c|c|c|}
\hline ID & Espécie & Letras & Acesso & Score & Cobertura - & Valor de e & $=$ ID mal. \\
\hline 671 & C. parapsilosis & 529 & GQ395610.1 & 970 & $100 \%$ & 0.0 & $99 \%$ \\
\hline 673 & C. albicans & 540 & FN652297.1 & 998 & $100 \%$ & 0.0 & $100 \%$ \\
\hline 674 & C. parapsilosis & 524 & FN652300.2 & 968 & $100 \%$ & 0.0 & $100 \%$ \\
\hline 675 & C. haemulonii & 382 & GQ402827.1 & 717 & $99 \%$ & 0.0 & $99 \%$ \\
\hline 680 & C. parapsilosis & 524 & FN652300.1 & 968 & $100 \%$ & 0.0 & $100 \%$ \\
\hline 681 & C. parapsilosis & 524 & FN652300.1 & 968 & $100 \%$ & 0.0 & $100 \%$ \\
\hline 682 & C. parapsilosis & 524 & FN652300.1 & 891 & $100 \%$ & 0.0 & $97 \%$ \\
\hline 687 & C. metapsilosis & 533 & AY391849.1 & 970 & $100 \%$ & 0.0 & $99 \%$ \\
\hline 689 & C. metapsilosis & 534 & AY391849.1 & 966 & $100 \%$ & 0.0 & $99 \%$ \\
\hline 697 & C. haemulonii & 392 & GQ402827 & 702 & $99 \%$ & 0.0 & $99 \%$ \\
\hline 699 & C. parapsilosis & 581 & GQ395610.1 & 1048 & $100 \%$ & 0.0 & $99 \%$ \\
\hline 703 & C. parapsilosis & 524 & FN652300.1 & 926 & $100 \%$ & 0.0 & $98 \%$ \\
\hline 710 & C. parapsilosis & 524 & FN652300.1 & 953 & $100 \%$ & 0.0 & $99 \%$ \\
\hline 734 & C. haemulonii & 392 & GQ402827 & 717 & $99 \%$ & 0.0 & $99 \%$ \\
\hline 742 & C. parapsilosis & 524 & FN652300.1 & 968 & $100 \%$ & 0.0 & $100 \%$ \\
\hline 745 & C. parapsilosis & 526 & EU564203 & 948 & $100 \%$ & 0.0 & $99 \%$ \\
\hline 750 & C. parapsilosis & 524 & FN652300.1 & 892 & $100 \%$ & 0.0 & $99 \%$ \\
\hline 751 & C. parapsilosis & 571 & GQ395610.1 & 1042 & $100 \%$ & 0.0 & $99 \%$ \\
\hline 756 & C. parapsilosis & 524 & FN652300.1 & 968 & $100 \%$ & 0.0 & $100 \%$ \\
\hline 772 & C. parapsilosis & 524 & EU564203.1 & 968 & $100 \%$ & 0.0 & $100 \%$ \\
\hline 778 & C. parapsilosis & 523 & EU564203.1 & 961 & $100 \%$ & 0.0 & $99 \%$ \\
\hline 810 & C. albicans & 540 & FN652297.1 & 998 & $100 \%$ & 0.0 & $100 \%$ \\
\hline 834 & C. parapsilosis & 527 & FN652300.1 & 953 & $100 \%$ & 0.0 & $99 \%$ \\
\hline 874 & C. parapsilosis & 525 & FN652300.1 & 963 & $100 \%$ & 0.0 & $99 \%$ \\
\hline 897 & C. albicans & 541 & FN652297.1 & 992 & $100 \%$ & 0.0 & $99 \%$ \\
\hline 931 & C. albicans & 542 & FN652297.1 & 977 & $100 \%$ & 0.0 & $99 \%$ \\
\hline 936 & C. parapsilosis & 524 & EU564203.1 & 957 & $100 \%$ & 0.0 & $99 \%$ \\
\hline 940 & C. albicans & 540 & FN652297.1 & 998 & $100 \%$ & 0.0 & $100 \%$ \\
\hline 945 & C. albicans & 524 & EU564203.1 & 968 & $100 \%$ & 0.0 & $100 \%$ \\
\hline 954 & C. albicans & 543 & FN652297.1 & 983 & $100 \%$ & 0.0 & $99 \%$ \\
\hline 965 & C. albicans & 541 & FN652297.1 & 992 & $100 \%$ & 0.0 & $100 \%$ \\
\hline 973 & C. albicans & 539 & AF455524.1 & 977 & $100 \%$ & 0.0 & $99 \%$ \\
\hline 981 & C. albicans & 524 & FN652297.1 & 987 & $100 \%$ & 0.0 & $99 \%$ \\
\hline 1017 & C. haemulonii & 397 & GQ402827.1 & 702 & $99 \%$ & 0.0 & $99 \%$ \\
\hline 1026 & C. albicans & 540 & FN652297.1 & 998 & $100 \%$ & 0.0 & $100 \%$ \\
\hline 1039 & C. parapsilosis & 532 & FN652300.1 & 924 & $100 \%$ & 0.0 & $98 \%$ \\
\hline 1041 & C. albicans & 540 & FN652297.1 & 971 & $100 \%$ & 0.0 & $99 \%$ \\
\hline 1043 & C. parapsilosis & 524 & EU564203.1 & 968 & $100 \%$ & 0.0 & $100 \%$ \\
\hline 1048 & C. parapsilosis & 524 & EU564203.1 & 963 & $100 \%$ & 0.0 & $100 \%$ \\
\hline 1063 & C. albicans & 541 & FN652297.1 & 992 & $100 \%$ & 0.0 & $99 \%$ \\
\hline 1082 & C. albicans & 541 & FN652297.1 & 987 & $100 \%$ & 0.0 & $99 \%$ \\
\hline
\end{tabular}

Letras: número de nucleotídeos presentes na região ITS; ID: identidade Máx: Máxima

Fonte: Moreira (2012) 
Figura 17: Alinhamento dos nucleotídeos, gerados no Blast

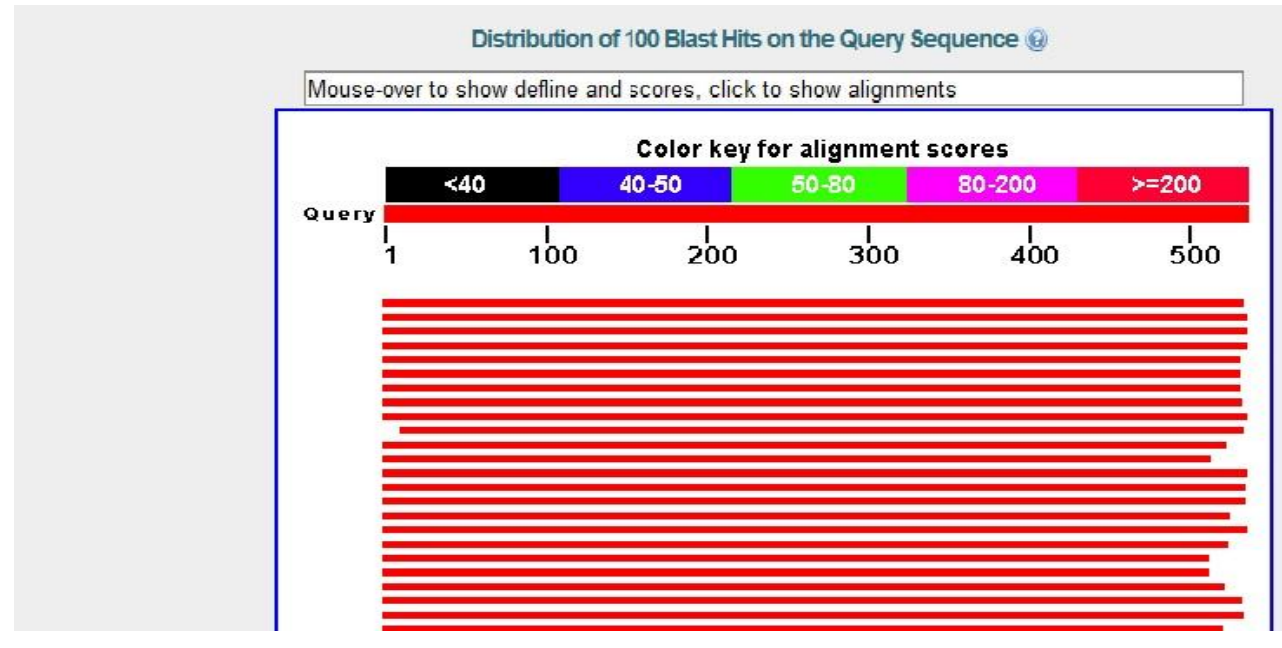

Figura 18: Frequência de leveduras isoladas da região vulvovaginal, identificadas através de provas fisiológicas e sequenciamento

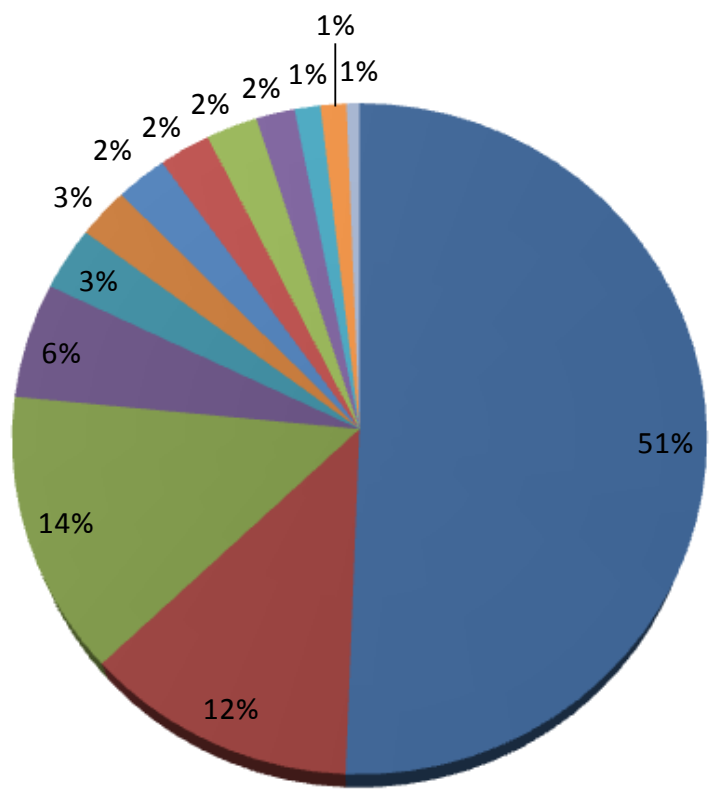
C.albicans
C. glabrata
C. parapsilosis
C. tropicalis
C. kefyr
C. famata
C. guilliermondii
Rhodotorulaspp
C. haemulonis
- Trichosporon spp
C. krusei
C. metapsilosis
C. Iusitaniae

Fonte: Moreira (2012) 
As quatro espécies mais frequentemente isoladas foram $C$. albicans $<C$. parapsilosis $<$ C. glabrata $<$ C. tropicalis.

4.6.1 Correlação Entre as Espécies e os grupos de Mulheres Assintomáticas, com CVV e com CVVR

A Figura 19 mostra a frequência das amostras, nos três grupos amostrais. Entre as amostras isoladas no grupo das assintomáticas, as espécies mais frequentemente isoladas foram C. albicans, C. glabrata, C. parapsilosis e Rhodotorula spp. Ao realizar uma comparação entre a frequência de isolamento de $C$. albicans com $C$. parapsilosis, $\mathrm{p}<0.0001$; os mesmos valores foram obtidos ao comparar $C$. albicans, com C. glabrata e Rhodotorula spp. Quando se comparou C. glabrata com C. paraps/losis, $\mathrm{p}=0.6375$. A diferença entre $C$. parapsilosis e Rhodotorula spp também não foi significativa $\mathrm{p}=0.00015$.

Figura 19: Frequência de leveduras, por grupo amostral

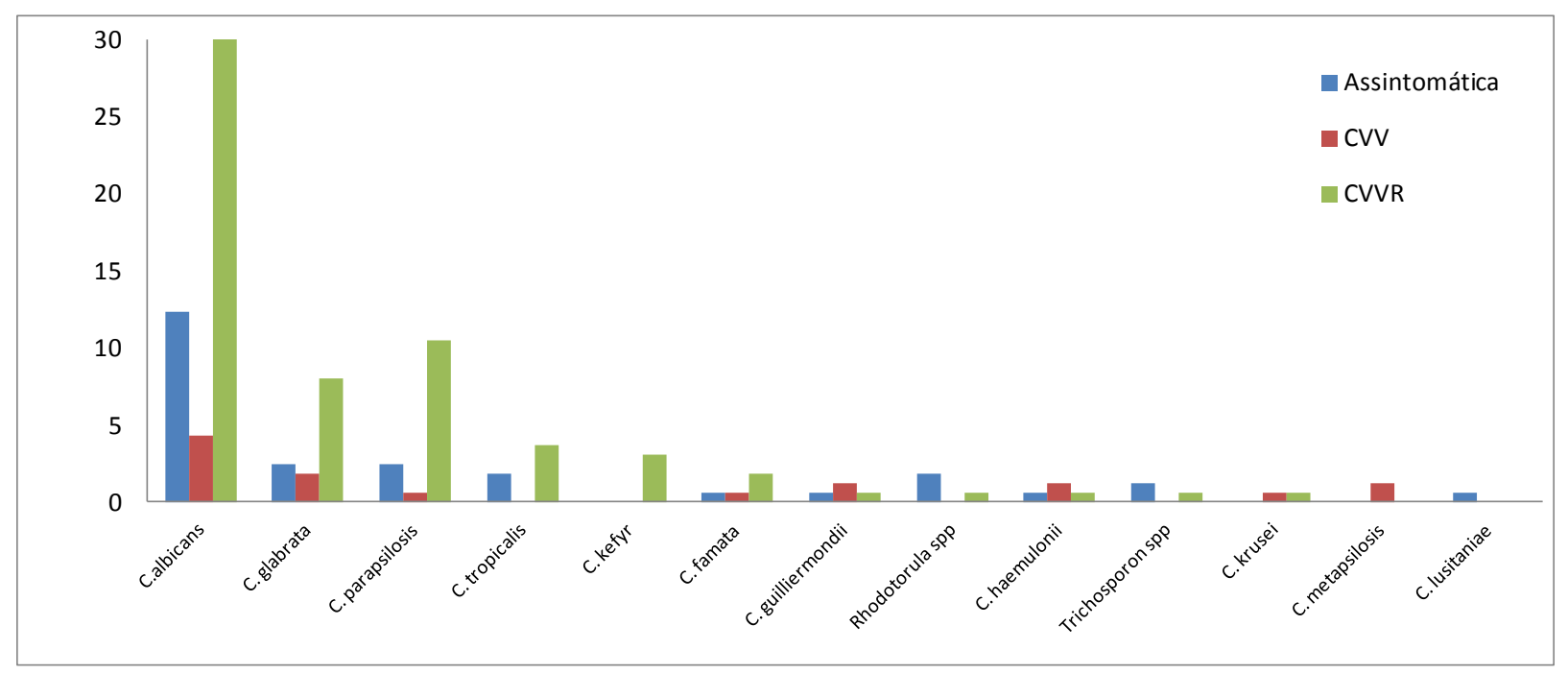

Fonte: Moreira (2012)

As espécies mais isoladas no grupo 1 foram $C$. albicans, C. parapsilosis e $C$. tropicalis. Realizou-se a comparação entre a frequência dessas três espécies. Comparando-se $C$. albicans com $C$. parapsilosis e $C$. tropicalis, $p<0.001$. Quando a comparação foi realizada entre C. parapsilosis e C. tropicalis, o valor de $p$ foi $=0.5291$. 
No grupo 2, as quatro espécies mais isoladas foram C. albicans, C. glabrata, C. parapsilosis e C. tropicalis. $\mathrm{Na}$ análise entre C. albicans, C. glabrata, C. tropicalis e C. parapsilosis, o valor de $p$, pelo ANOVA foi $p<0,001$. Ao comparar C. glabrata com $C$. parapsilsis, $\mathrm{p}=0.6061$ e, C. glabrata com $C$. tropicalis $\mathrm{p}=0.012$. A diferença entre $\mathrm{C}$. parapsilosis e $C$. tropicalis foi pequena, neste grupo $p=0.0029$.

Um fato interessante a ser notado é que $C$. glabrata não foi isolada no grupo CVV.

\subsection{Produção de Exoenzimas}

\subsubsection{Proteinase}

A produção de proteinase foi observada em $88 \%$ dos isolados. $E$, quando se avaliou a intensidade da produção, $63 \%$ foram fortemente produtores dessa enzima. A Figura 20 mostra o índice geral da produção de proteinase.

Figura 20: Índice de proteinase em todas as amostras

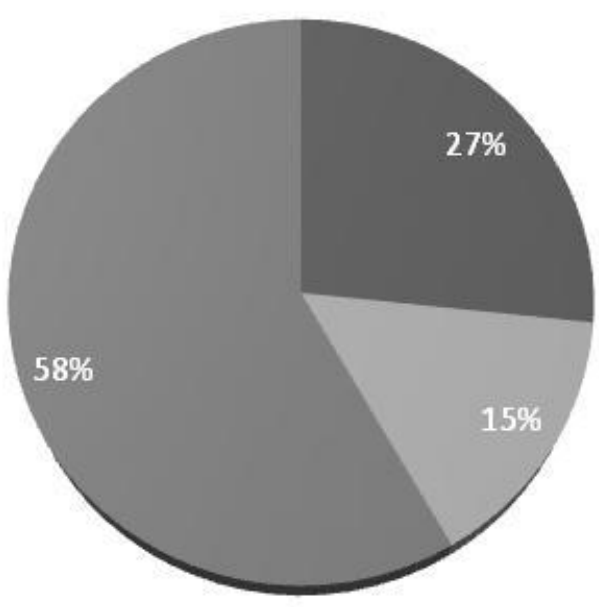

-1-2 23

Índices: 1: Não produtor; 2. Produtor; 3. Fortemente produtor Fonte: Moreira (2012)

Na Tabela 12 estão descritas a produção de proteinase, por espécie de levedura. 
Tabela 12: Produção de proteinase, por espécie de levedura

\begin{tabular}{cccc}
\hline Espécie & \multicolumn{4}{c}{ Índice } \\
& $\mathbf{1}$ & $\mathbf{2}$ & $\mathbf{3}$ \\
\hline C. albicans & $25,6 \%(21 / 82)$ & $11,5 \%(7 / 82)$ & $66,7 \%(54 / 82)$ \\
C. glabrata & $20 \%(4 / 20)$ & $15 \%(3 / 20)$ & $65 \%(13 / 20)$ \\
C. parapsilosis & $18,2 \%(4 / 22)$ & $4,5 \%(1 / 22)$ & $66,7 \%(17 / 22)$ \\
C. tropicalis & $33,3 \%(3 / 9)$ & 0 & $66,7 \%(6 / 9)$ \\
C. kefyr & 0 & 0 & $100 \%(5 / 5)$ \\
C. famata & $25 \%(1 / 4)$ & $25 \%(1 / 4)$ & $50 \%(2 / 4)$ \\
C. guilliermondii & $25 \%(1 / 4)$ & $50 \%(2 / 4)$ & $25 \%(1 / 4)$ \\
Rhodotorula spp & $75 \%(3 / 4)$ & 0 & $25 \%(1 / 4)$ \\
C. haemulonii & $25 \%(1 / 4)$ & $50 \%(2 / 4)$ & $25 \%(1 / 4)$ \\
Trichosporon spp & $66,7 \%(2 / 3)$ & 0 & $33,3 \%(1 / 3)$ \\
C. krusei & 0 & $50 \%(1 / 2)$ & $50 \%(1 / 2)$ \\
C. metapsilosis & 0 & $100 \%(2 / 2)$ \\
C. lusitaniae & $100 \%(1 / 1)$ & 0 \\
\hline
\end{tabular}

Fonte: Moreira (2012)

Entre as quatro espécies de Candida mais frequentemente isoladas, a maioria foi fortemente produtora de proteinase,com índices que variaram entre 65\% e 67\%. Dentre as espécies menos isoladas, a produção de proteinase também foi observada na maior parte destes. Já as leveduras não- Candida, como Rhodotorula spp e Trichosporon spp apresentaram pouca produção dessa enzima. Na Figura 21 está descrita a produção de proteinase, por grupo de mulheres. 
Figura 21: Comparação da produção de proteinase, por grupo amostral

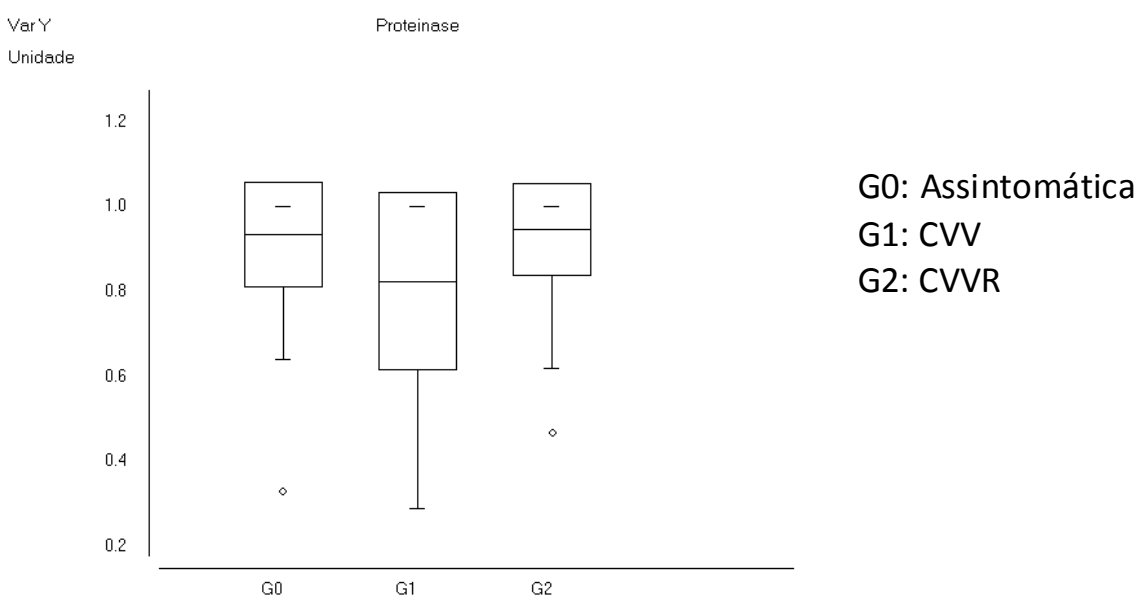

Fonte: Moreira (2012)

\subsubsection{Correlação entre proteinase e o grupo amostral}

Apesar da maior quantidade de produção de proteinase, no grupo das CVV, a análise da expressão de proteinase, pelo método Kruskal Wallis, dos três grupos amostrais não revelou que diferença estatisticamente entre eles. A análise da correlação entre a produção de proteinase, por grupo e por espécie também não revelou diferenças nos três grupos amostrais.

\subsubsection{Correlação entre a produção de proteinase, as espécies e os grupos amostrais}

Para esse experimento considerou-se as amostras como produtoras e não produtoras de proteinase. A primeira análise foi realizada entre a produção dessa enzima. No grupo das assintomáticas, a correlação foi possível entre $C$. albicans, $C$. glabrata e C. parapsilosis. No grupo 1 a correlação entre a produção de proteinase foi realizada entre as leveduras $C$. albicans e $C$. tropicalis $(p=0.0146)$, pelo ANOVA. Através do teste de análise multivariada, Kruskal Wallis, a análise entre os grupos e as espécies não detectou diferença estatisticamente significativo entre eles. 
Para as leveduras do grupo 2, o valor de $p=0.9746$, entre os grupos e as espécies. Ao se pretender fazer uma análise geral de espécies, produção de proteinase e grupos, não foi observada diferença estatisticamente significante (Figura 22).

Figura 22: Produção de proteinase por espécies pertencente ao grupo das assintomáticas

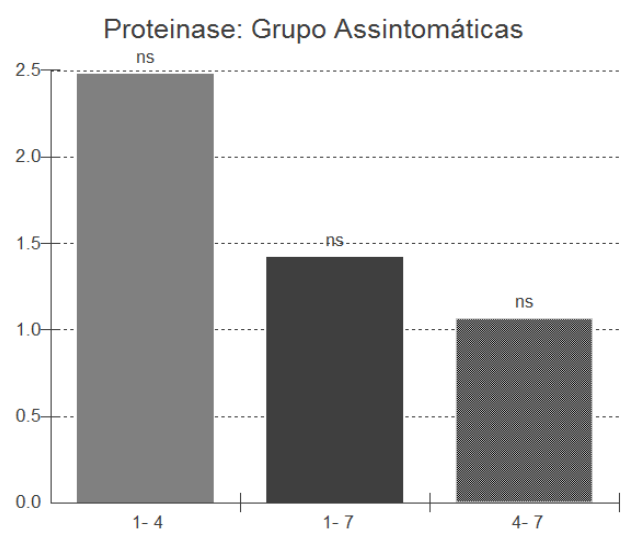

Leveduras do grupo das assintomáticas 1. C. albicans; 4. C. glabrata; 7. C. parapsilosis; ns: não significante

Fonte: Moreira (2012)

Figura 23: Produção de proteinase por espécies pertencente ao grupo das CVV

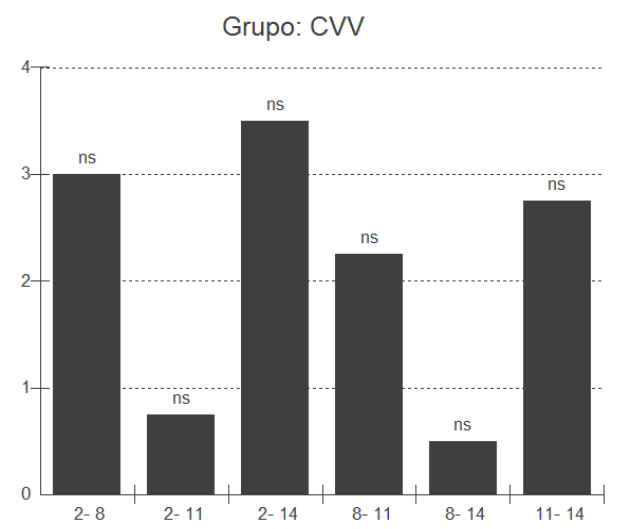

Leveduras isoladas no grupo das CVV: 2. C. albicans; 8. C. parapsilosis; 11. C. tropicalis 14. C. famata.

Fonte: Moreira (2012) 
Figura 24: Produção de proteinase por espécies pertencente ao grupo das CVVRs

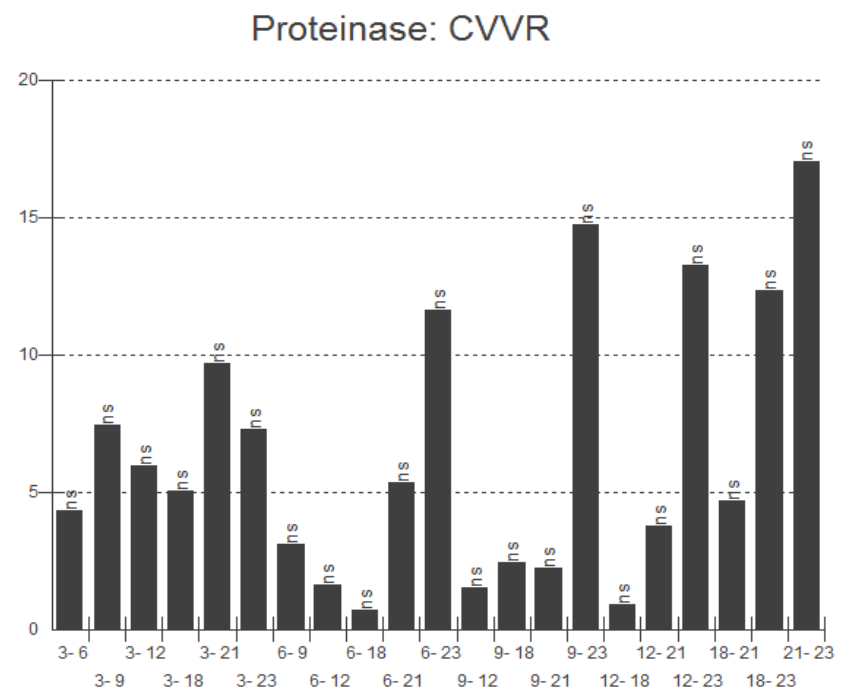

Leveduras isoladas no grupo das CVVRs 3. C. albicans; 6. C. glabrata; 9. C. parapsilosis; 12. C. tropicalis; 18. C. kefyr, 21. C. haemulonii; 23. C. metapsilosis. Fonte: Moreira (2012)

\subsection{Fosfolipase}

A produção de fosfolipase foi avaliada nos 162 isolados. Os resultados estão descritos na Figura 25. 
Figura 25: Índice geral de produção de fosfolipase pelas espécies de leveduras

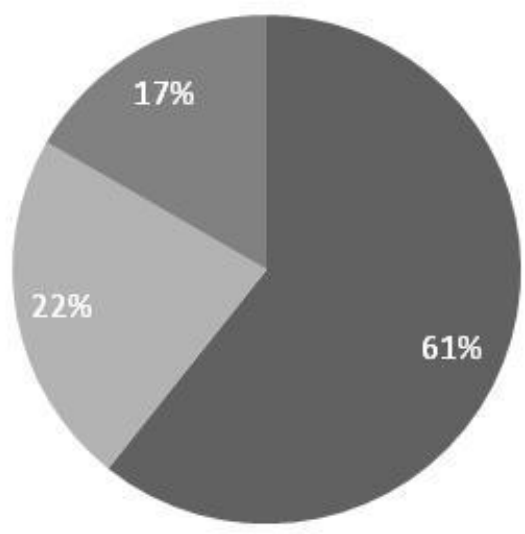

Índices 1. Não produtor; 2. Produtor; 3. Fortemente produtor de proteinase Fonte: Moreira (2012)

A produção de fosfolipase ocorreu em trinta e nove por cento das amostras. A Tabela 13 traz os resultados da atividade fosfolipídica das 162 espécies de leveduras isoladas de conteúdo vaginal.

Tabela 13: Produção de fosfolipase, por índice e por espécie

\begin{tabular}{cccc}
\hline & \multicolumn{3}{c}{ Índice } \\
Fosfolipase & $\mathbf{1}$ & $\mathbf{2}$ & $\mathbf{3}$ \\
\hline C. albicans & $46,9 \%(38 / 82)$ & $30,5 \%(25 / 82)$ & $23,2 \%(19 / 82)$ \\
C. glabrata & $90 \%(18 / 20)$ & $10 \%(2 / 20)$ & \\
C. parapsilosis & $86,3(19 / 22)$ & $4,5 \%(1 / 22)$ & $9,9 \%(2 / 22)$ \\
C. tropicalis & $55,5 \%(5 / 9)$ & $33,3 \%(3 / 9)$ & $11,1 \%(1 / 9)$ \\
C. kefyr & $40 \%(2 / 5)$ & $40 \%(2 / 5)$ & $20 \%(1 / 5)$ \\
C. famata & $50 \%(2 / 4)$ & $25 \%(1 / 4)$ & $25 \%(1 / 4)$ \\
C. guilliermondii & $75 \%(3 / 4)$ & $25 \%(1 / 4)$ & \\
Rhodotorula spp & $75 \%(3 / 4)$ & $25 \%(1 / 4)$ & \\
C. haemulonii & $100 \%(4 / 4)$ & & $33,3 \%(1 / 3)$ \\
Trichosporon spp & $66,6 \%(2 / 3)$ & & \\
C. krusei & $100 \%(2 / 2)$ & & \\
C. metapsilosis & $100 \%(2 / 2)$ & & \\
C. lusitaniae & $100 \%(1 / 1)$ & &
\end{tabular}

Fonte: Moreira (2012) 
A produção de fosfolipase foi notada em $53.7 \%$ dos isolados de C. albicans, enquanto $90 \%$ dos isolados de C. glabrata não produziu essa enzima. Dentre as amostras de C. parapsilosis, $86,3 \%$ não foram produtores de fosfolipase e, mais da metade dos isolados de $C$. tropicalis não produziram essa enzima.

\subsubsection{Correlação entre a produção de fosfolipase, as espécies e os grupos amostrais}

Como praticamente metade dos isolados não foram produtores de fosfolipase, $(47,3 \%)$ optou-se por realizar duas correlações: entre as amostras produtoras de fosfolipase e entre as amostras não produtoras dessa enzima.

As espécies mais produtoras de fosfolipase foram: $C$. albicans, $C$. tropicalis e $C$. parapsilosis. Não foram observadas diferenças entre a atividade fosfolipásica dos isolados de $C$. albicans e $C$. tropicalis. Porém, $C$. albicans foi mais produtora de fosfolipase do que $C$. parapsilosis $(\mathrm{p}=0.0679)$.

A realização da análise dos grupos amostrais, por espécie, somente foi possível a entre os isolados de C. albicans pertencentes aos três grupos amostrais. Quando se comparou a produção de fosfolipase pelos isolados do grupo das assintomáticas e das $C V V$, uma pequena diferença foi observada ( $p=0.0172)$; comparando-se o grupo das CVV com o das CVVR, não se observou diferenças estatisticamente significativas ( $p=0,0052)$. A maior diferença foi observada entre o grupo das assintomáticas e das CVVRs ( $p=0.5869$ ). Na Figura 25 há a comparação entre a produção de fosfolipase, nos três grupos amostrais. 
Figura 26: Comparação da produção de fosfolipase, pelos grupos amostrais

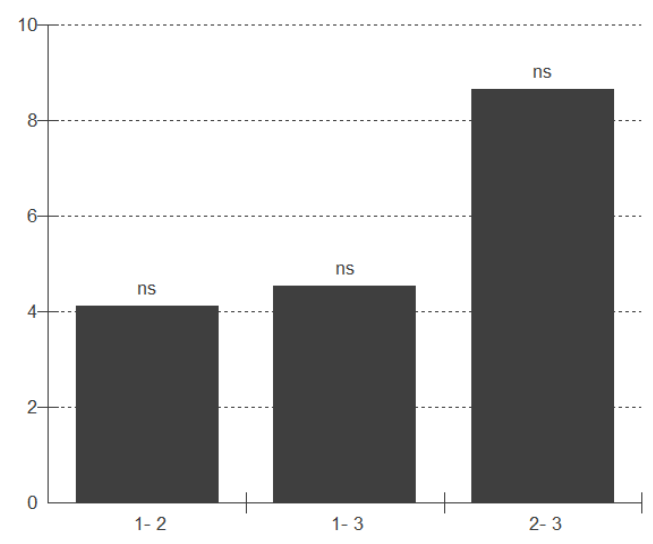

1. C. albicans, grupo das assintomáticas; 2. C. albicans, grupo das CVV; 3. C. albicans, grupo das CVVRs

Fonte: Moreira, (2012)

A avaliação da não produção de fosfolipase apontou que as espécies que menos produziram fosfolipase foram $C$. glabrata, C. albicans, C. parapsilosis, C. kefyr e $C$. guilliermondii.

A maior diferença estatística foi observada entre a não produção de fosfolipase pelas amostras de C. glabrata e C. parapsilosis ( $\mathrm{p}=0.1589)$.

\subsection{Sensibilidade aos antifúngicos}

\subsection{1 "Etest"}

A sensibilidade dos 162 isolados foi testada, pelo método de "Etest", frente as seguintes drogas: anfoterlcina $B$, cetoconazol, caspofungina, voriconazol, fluconazol e itraconazol. Os resultados estão sintetizados na Tabela 14 e na Tabela 15 há a diferenciação dos CIM, por espécies de leveduras.. 
Tabela 14: Valores de CIM apresentados amostras de leveduras pelo método do Etest

\begin{tabular}{|c|c|c|c|c|c|c|c|}
\hline Antifúngico & CIM médio & CIM 50 & CIM 90 & Variação CIM & $\mathbf{S}$ & $\mathbf{R}$ & SDD \\
\hline Anfotericina B & 1,19 & 0,057 & 1,47 & $0,002-32$ & 91,3 & 8,64 & \\
\hline Cetoconazol & 1,12 & 0,007 & 0,013 & $0,002-32$ & 96,91 & 3,09 & \\
\hline Caspofungina & 2,77 & 0,149 & 9,5 & $0,002-32$ & 91,35 & 8,64 & \\
\hline Voriconazol & 1,45 & 0,006 & 0,125 & $0,002-32$ & 95,68 & 4,32 & 2,27 \\
\hline Fluconazol & 13,03 & 0,121 & 2,52 & $0,002-256$ & 95,06 & 4,94 & \\
\hline Itraconazol & 1,77 & 0,566 & 14,72 & $0,002-32$ & 87,04 & 12,96 & 11,11 \\
\hline
\end{tabular}

CIM: Concentração Inibitória Mínima; S: Sensível; R: Resistente; SDD: Sensibilidade dose dependente Fonte: Moreira (2012)

Frente a anfotericina $B$, o valor médio de concentração inibitória mínima foi de 1 , $189 \mathrm{ug} / \mathrm{mL}$. A resistência a essa droga foi notada em $8,64 \%$ dos isolados; frente ao cetoconazol, o CIM médio foi de $1,123 \mu \mathrm{g} / \mathrm{mL}$ e a resistência foi observada em 3,09\% dos isolados; frente a caspofungina, o CIM médio foi de $2,77 \mu \mathrm{g} / \mathrm{mL}$ e a não sensibilidade observada foi de $8,64 \%$. Em relação ao voriconazol, $4,32 \%$ dos isolados foram considerados resistentes e 2,42\% apresentaram sensibilidade dependente da dose. O CIM médio do fluconazol foi de $13,03 \mu \mathrm{g} / \mathrm{mL}$ e, a resistência foi notada em $4,94 \%$ dos isolados. Os isolados apresentaram maior resistência ao itraconazol, com $12,96 \%$ e $11,11 \%$ foram considerados como sensibilidade dose dependente. O CIM médio foi de $1,76 \mu \mathrm{g} / \mathrm{mL}$. 
Tabela 15: Variação de $\mathrm{CIM}_{50}$ e CIM 90, sensibilidade e resistência de isolados de leveduras

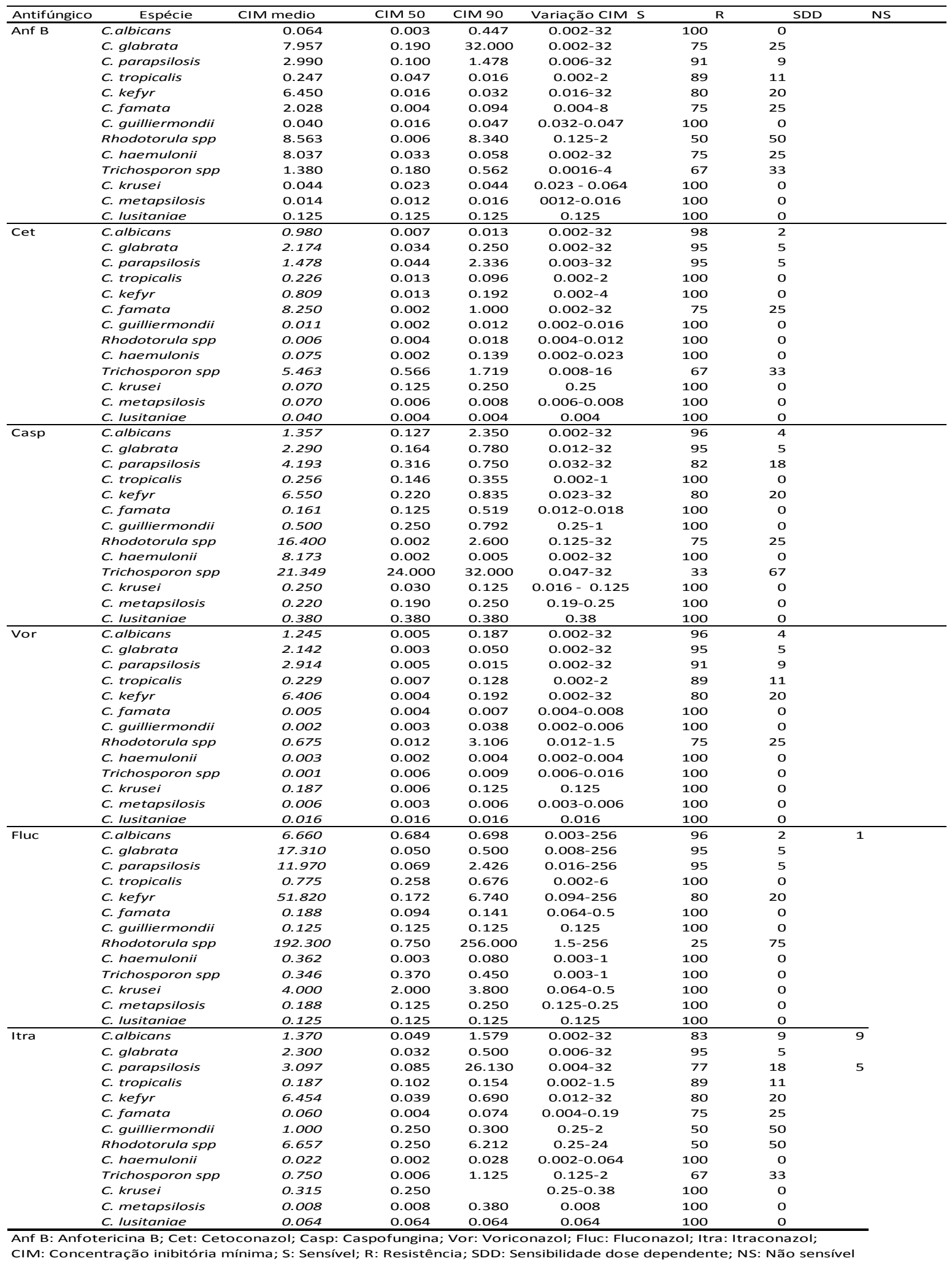

Fonte: Moreira (2012) 


\subsubsection{Microdiluição (Eucast Edef7.1 e CLSI)}

As amostras que foram consideradas resistentes ou sensibilidade intermediária aos antifúngicos anfotericina $\mathrm{B}$, itraconazol e fluconazol, pelo "Etest" foram submetidas a ensaios de microdiluição (EUCAST EDef7.1 e CLSI M27S3). Tendo o método do CLSI M27S3 como método de referência. Os resultados encontram-se descritos nos itens abaixo.

\subsubsection{Resistência a anfotericina $B$}

Dez isolados foram considerados como resistentes pela técnica do "Etest" e, selecionados para a realização das técnicas de microdiluição (EUCAST Edef7.1 e CLSIM27S3). Os resultados estão descritos nas Tabelas 16, 17 e 18.

Tabela 16: Comparação dos resultados obtidos pelo "Etest" com os demais métodos para a anfotericina $B$

\begin{tabular}{cccccccc}
\hline Amostra & Espécie & Etest & Classif. & EUCAST Edef7.0 & Classif. & CLSIM27S3 & Classif. \\
\hline 669 & Rhodotorula spp & 32 & $\mathrm{R}$ & 0.25 & $\mathrm{~S}$ & 0.5 & $\mathrm{~S}$ \\
696 & C. glabrata & 6 & $\mathrm{R}$ & 0.5 & $\mathrm{~S}$ & 1 & $\mathrm{~S}$ \\
697 & C. haemulonii & 32 & $\mathrm{R}$ & 0.25 & $\mathrm{~S}$ & 0.5 & $\mathrm{~S}$ \\
698 & C. kefyr & 32 & $\mathrm{R}$ & 0.5 & $\mathrm{~S}$ & 1 & $\mathrm{~S}$ \\
723 & C. glabrata & 16 & $\mathrm{R}$ & 0.5 & $\mathrm{~S}$ & 1 & $\mathrm{~S}$ \\
742 & C. parapsilosis & 32 & $\mathrm{R}$ & 0.5 & $\mathrm{~S}$ & 1 & $\mathrm{~S}$ \\
747 & C. glabrata & 32 & $\mathrm{R}$ & 1 & $\mathrm{~S}$ & 1 & $\mathrm{~S}$ \\
750 & C. parapsilosis & 32 & $\mathrm{R}$ & 1 & $\mathrm{~S}$ & 1 & $\mathrm{~S}$ \\
780 & C. glabrata & 32 & $\mathrm{R}$ & 0.25 & $\mathrm{~S}$ & 1 & $\mathrm{~S}$ \\
1046 & Trichosporon spp & 4 & $\mathrm{R}$ & 0.25 & $\mathrm{~S}$ & 0.5 & $\mathrm{~S}$ \\
\hline
\end{tabular}
Classif.: Classificação; S: Sensível; R: resistente Fonte: Moreira (2012)

Todos os isolados que haviam sido considerados resistentes, a anfotericina B forma sensíveis a anfotericina $B$, pelas duas técnicas de microdiluição.

\subsubsection{Resistência ao itraconazol}


Os vinte e nove isolados considerados resistentes ou sensibilidade dose dependente, ao itraconazol, pela técnica de difusão em ágar "Etest" foram submetidos aos ensaios de microdiluição. Os resultados estão na Tabela 17.

Dentre os isolados considerados SDD, no Etest, 57,6\% (8/14) foram sensíveis, nos dois métodos de microdiluição; 3 foram considerados como SDD, no Eucast e sensíveis no CLSI e três foram SDD nos três métodos. Dentre os quinze isolados resistentes ao itraconazol, pelo Etest, 53\% (8/15) foram sensíveis aos dois métodos de microdiluição; 3 foram SDD nos dois métodos de microdiluição; 3 foram SDD no Eucast e sensíveis, no Etest e um isolado foi resistente, nos três métodos.

Ao final desses experimentos, tendo os ensaios de microdiluição (CLSIM27S3), como referência, conclui-se que seis isolados $(3,7 \%)$ foram considerados como sensibilidade dose dependente (SDD) e um isolado foi resistente ao itraconazol.

Dos seis isolados SDD, um foi de C. albicans; 2 C. glabrata; 1 de C. guilliermondii; 1 de $C$. parapsilosis e 1 Trichosporon spp. Um isolado que foi resistente foi de C. glabrata.

\subsubsection{Resistência ao fluconazol}

Doze isolados foram considerados resistentes ou SDD ao fluconazol, pelo "Etest" foram testados pelos dois métodos de microdiluição. Os resultados estão na Tabela 18.

Oito dos doze resistentes, ao fluconazol, pelo Etest, seis foram sensíveis nos dois métodos de microdiluição; dois foram resistentes, no Eucast. No CLSI, um foi considerado como SDD e um sensível a esse antifúngico. 


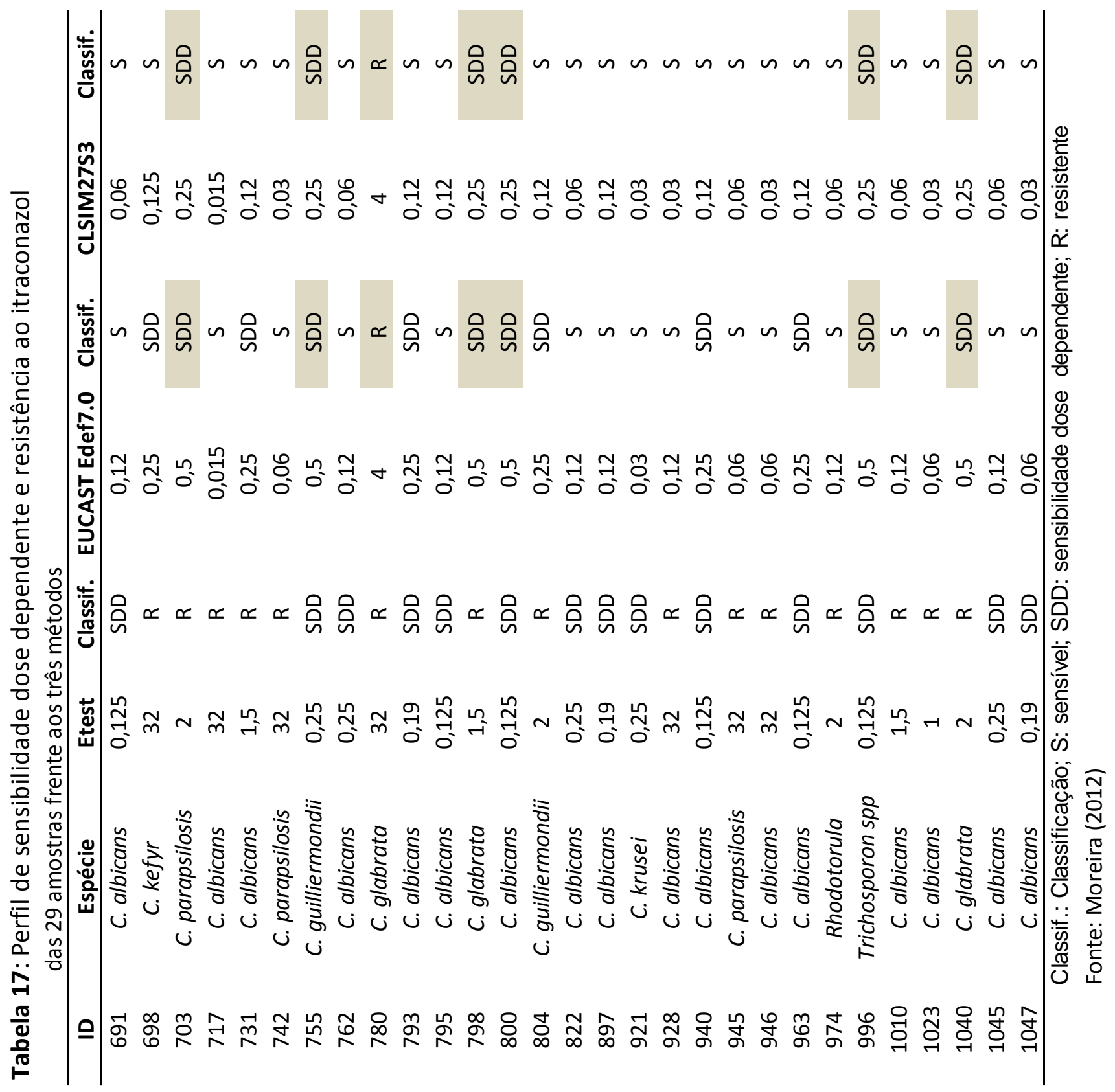


Tabela 18: Perfil de sensibilidade dose dependente e resistência ao fluconazol das 12 amostras frente aos três métodos

\begin{tabular}{cccccccc}
\hline ID & Espécie & Etest & Classif. & EUCAST Edef7.0 & Classif. & CLSIM27S3 & Classif. \\
\hline 674 & C. parapsilosis & 16 & SDD & 8 & $\mathrm{R}$ & 16 & SDD \\
698 & C. kefyr & 256 & $\mathrm{R}$ & 0.25 & $\mathrm{~S}$ & 0.125 & $\mathrm{~S}$ \\
717 & C. albicans & 256 & $\mathrm{R}$ & 0.12 & $\mathrm{~S}$ & 0.12 & $\mathrm{~S}$ \\
742 & C. parapsilosis & 256 & $\mathrm{R}$ & 0.5 & $\mathrm{~S}$ & 0.25 & $\mathrm{~S}$ \\
775 & C. glabrata & 256 & $\mathrm{R}$ & 16 & $\mathrm{R}$ & 16 & $\mathrm{SDD}$ \\
780 & C. glabrata & 16 & $\mathrm{SDD}$ & 16 & $\mathrm{R}$ & 16 & $\mathrm{SDD}$ \\
922 & C. krusei & 16 & $\mathrm{SDD}$ & 32 & $\mathrm{R}$ & 16 & $\mathrm{SDD}$ \\
946 & C. albicans & 256 & $\mathrm{R}$ & 0.5 & $\mathrm{~S}$ & 0.25 & $\mathrm{~S}$ \\
974 & Rhodotorula spp & 256 & $\mathrm{R}$ & 0.25 & $\mathrm{~S}$ & 0.12 & $\mathrm{~S}$ \\
977 & Rhodotorula spp & 256 & $\mathrm{R}$ & 0.25 & $\mathrm{~S}$ & 0.12 & $\mathrm{~S}$ \\
1040 & C. glabrata & 16 & $\mathrm{SDD}$ & 8 & $\mathrm{R}$ & 4 & $\mathrm{~S}$ \\
1044 & Rhodotorula spp & 256 & $\mathrm{R}$ & 8 & $\mathrm{R}$ & 4 & $\mathrm{~S}$ \\
\hline
\end{tabular}

ID: Identificação; Classif.: Classificação; S: Sensível; SDD: Sensibilidade dose dependente; R: resistente

Fonte: Moreira (2012)

Os quatro isolados SDD no Etest foram resistentes no Eucast e, três foram SDD no CLSI, concordando com o Etest.

Após a realização dos ensaios de microdiluição, tendo o CLSIM27S3, as amostras consideradas SDD ou R, por grupo e espécie foram analisadas. Os resultados estão descritos na Tabela 19. 
Tabela 19: Perfil das amostras que apresentaram resistência ou sensibilidade dose dependente, através do método de referência: CLSIM27S3

\begin{tabular}{ccccc}
\hline & ID & Espécie & Classif. & Grupo \\
\hline Fluconazol & 674 & C. parapsilosis & SDD & CVVR \\
& 775 & C. glabrata & SDD & CVVR \\
& 780 & C. glabrata & SDD & CVVR \\
& 922 & C. krusei & SDD & CVVR \\
& 1040 & C. glabrata & $\mathrm{R}^{*}$ & Assintomática \\
& 1044 & Rhodotorula spp & $\mathrm{R}^{*}$ & Assintomática \\
\hline Itraconazol & 703 & C. parapsilosis & $\mathrm{SDD}$ & Assintomática \\
& 755 & C. guilliermondii & SDD & CVV \\
& 780 & C. glabrata & $\mathrm{R}$ & CVVR \\
& 798 & C. glabrata & SDD & CVVR \\
& 800 & C. albicans & SDD & CVV \\
& 996 & Trichosporon spp & SDD & CVVR \\
& 1040 & C. glabrata & SDD & Assintomática \\
\hline
\end{tabular}

* Isolados R no Etest e no Eucast

ID: Identificação; Classif.: Classificação; SDD: Sensibilidade dose dependente; R: Resistente

Fonte: Moreira (2012)

A sensibilidade dependente da dose, ao fluconazol foi observada em quatro isolados, pertencentes ao grupo das CVVR. Dois isolados foram considerados sensíveis ao CLSI porém, apresentaram elevados valores de CIM e, no Eucast foram resistentes.

Três isolados de C. glabrata apresentaram sensibilidade reduzida ao itraconazol, inclusive, o isolado 780 foi resistente a esse antifúngico. Este mesmo isolado já se apresentara SDD ao fluconazol. E, outro, de C. glabrata (1040), pertencente ao grupo das assintomáticas, também apresentou sensibilidade reduzida aos dois antifúngicos.

\subsection{Perfil genotípico}

\subsubsection{Tipagem molecular das leveduras isoladas}

Para o cálculo do número de amostras, para realização da cariotipagem adotouse os valores de $5 \%$ de erro amostral, intervalo de confiança de $90 \%$, com percentual máximo de $10 \%$, entre as amostras, obtendo-se o número de 64 isolados. Sendo $42 C$. albicans; 7 C. glabrata; 3 C. kefyr, 8 C. parapsilosis e 4 C. tropicalis. 


\subsubsection{Estimativa do peso molecular das bandas de Candida Spp}

As bandas das amostras analisadas variaram entre $275 \mathrm{~kb}$ a $4100 \mathrm{~kb}$. A figura 25 exibe a documentação fotográfica de um gel de agarose a $0,8 \%$ corado com brometo de etídio. A Figura 25 traz uma representação fotográfica de um gel.

Foram realizadas duas análises: uma análise visual, na qual realizou-se a contagem das bandas, com auxilio do "software" e outra com a construção de dendograma, realizado com auxílio do programa "Bionumerics", com a finalidade de se verificar a similaridade entre os isolados.

Figura 26: Perfil cromossômico de diferentes isolados de Candida spp, através do PFGE em gel de agarose a $0,8 \%$

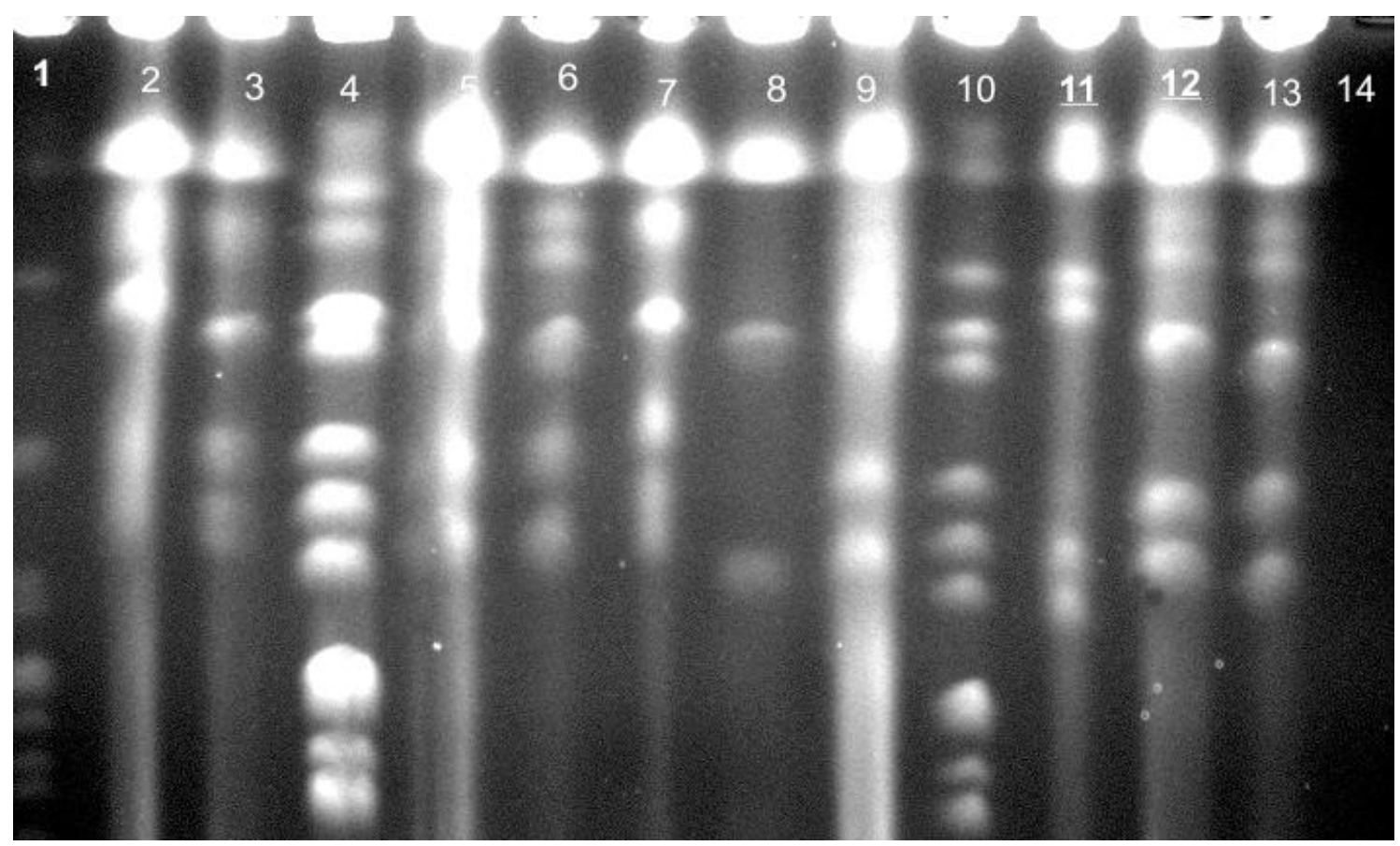

Eletroforese em gel de agarose. 1) Padrão de peso molecular (Saccharomyces cerevisae, de 225 a 2.200kb (Bio Rad/USA) ; 2) ATCC C. albicans 64548; 3) 691: C. albicans; 4) 656: C. glabrata; 5) 946: C. albicans; 6) 688: C. albicans; 7) 716: C. albicans; 8) 866: C. albicans; 9) 684: C. albicans; 10) 657: C. glabrata; 11) 680: C. parapsilosis; 12) 793: C. albicans; 13) 762: C. albicans; 14. Controle negativo. Fonte: Moreira (2012)

As Figuras 27 a 32 mostram os dendogramas realizados nas espécies de Candida spp. A Figura 30 a apresenta o número e a variação do peso molecular das 
bandas dos isolados de $C$. albicans. A maior parte dos isolados apresentara entre seis e oito bandas, com variação de peso molecular entre 275 a $4100 \mathrm{~kb}$.

Figura 27: Dendograma dos isolados de Candida glabrata, a partir das bandas eletroforéticas
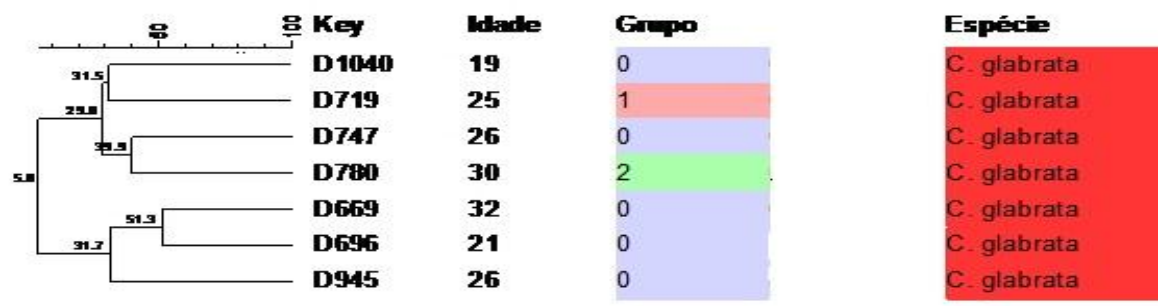

Fonte: Moreira (2012)

Figura 28: Dendograma dos isolados de Candida kefyr, a partir das bandas eletroforéticas
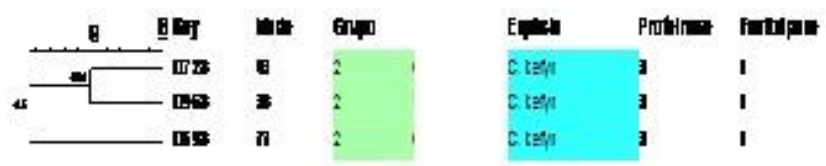

Fonte: Moreira (2012)

Figura 29: Dendograma dos isolados de Candida tropicalis, a partir das bandas eletroforéticas
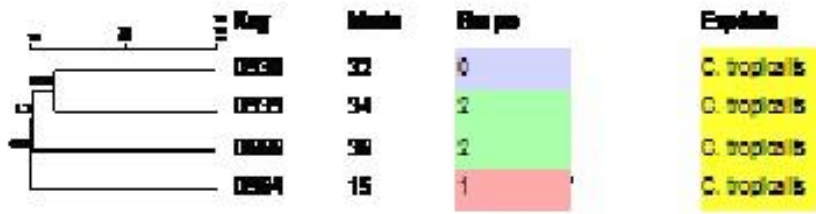

Fonte: Moreira (2012) 
Figura 30: Dendograma dos isolados de Candida albicans, a partir das bandas eletroforéticas

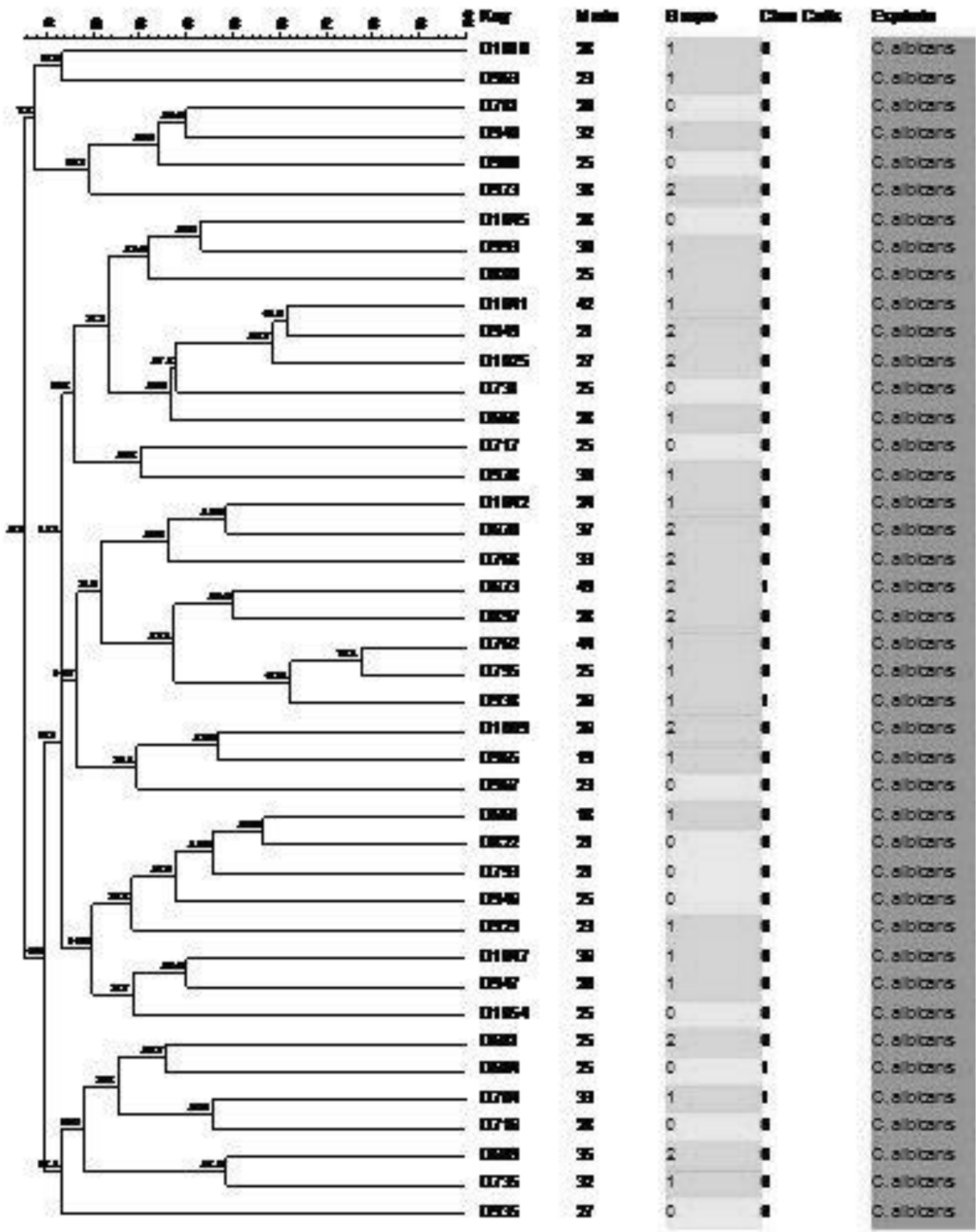

Fonte: Moreira (2012) 
Figura 31: Dendograma dos isolados de Candida parapsilosis, a partir das bandas eletroforéticas

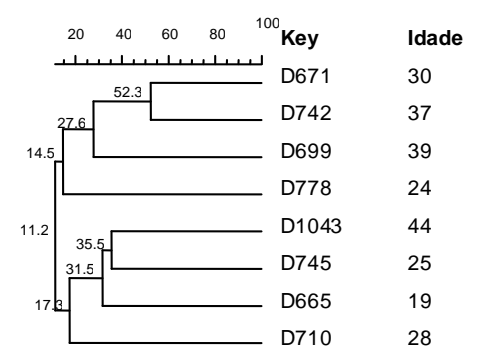

$\begin{array}{ll}\text { Grupo } & \text { Clue Cells } \\ 1 & 0 \\ 2 & 0 \\ 0 & 1 \\ 2 & 0 \\ 0 & 0 \\ 0 & 0 \\ 2 & 0 \\ 2 & 0\end{array}$

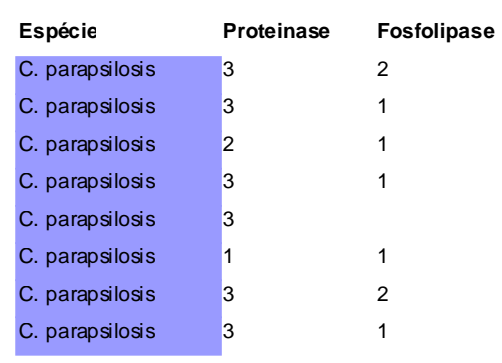

Fonte: Moreira (2012)

Tabela 20: Informações gerais sobre as espécies e o PFGE

\begin{tabular}{cccc}
\hline Espécie & Peso molecular & Bandas & no \\
\hline C albicans & $4100 k b-275 k b$ & 9 & 3 \\
& & 8 & 8 \\
& & 7 & 10 \\
& & 6 & 12 \\
& & 5 & 3 \\
C glabrata & $2800 k b-275 k b$ & 10 & 1 \\
& & 9 & 2 \\
\hline C kefyr & $4100 k b-300 k b$ & 5 & 1 \\
& & 7 & 2 \\
\hline C parapsilasis & $2500 k b-275 k b$ & 11 & 1 \\
& & 9 & 1 \\
& & 8 & 3 \\
& & 6 & 3 \\
\hline C tropicalis & $3400 k b-300 k b$ & 4 & 2 \\
& & 9 & 2 \\
\hline
\end{tabular}

$\mathrm{Kb}$ : quilobases

Fonte: Moreira (2012)

Embora a análise visual pudesse sugerir que poderia haver isolados semelhantes, análise realizada através de dendograma indica que não foram observadas similaridade ( $>90 \%$ ) entre as cepas analisadas, ou seja, cada uma das 42 
amostras apresentavam perfis de cariotipos próprios. A maior similaridade foi de 77.4 e, ambos eram pertencentes ao grupo das primárias.

A maior parte dos isolados de C. glabrata apresentaram 8 bandas de cromossomos. O dendograma dessa espécie mostra que os isolados não apresentaram similaridade.

A análise do dendograma mostra que não houve similaridade entre os isolados de $C$. kefyr e a análise visual mostrou que 2 isolados apresentaram o mesmo número de bandas cromossômicas.

Embora a análise visual dos isolados de $C$. tropicalis sugerisse que poderia haver a similaridade entre os isolados, a análise do dendograma apontou que há uma grande distancia entre todos os isolados. O mesmo fato foi observado entre os isolados de $C$. parapsilosis. 
A vagina é um ecossistema com biotipo original que apresenta características próprias, de acordo com a ecologia. Este ecossistema é dinâmico, mas possui um equilíbrio tênue. A alteração deste pode levar a uma infecção do trato genital feminino, ou a uma vaginite (KARAGOZOV et al., 2004).

O diagnóstico dessas infecções é frequentemente realizado com base nos sinais e sintomas clínicos (LANDERS et al., 2004), contudo, não realização de exames auxiliares pode ser passiva de erros, as mulheres podem ser portadoras de vários agentes etiológicos, como vírus, bactérias ou fungos ou mesmo um misto de microorganismos.

No presente estudo observamos que $62 \%$ das mulheres que apresentavam queixa de desconforto vaginal (prurido ou leucorréia abundante), 64\% apresentaram diagnóstico confirmado de leveduras (Gram e cultura positivos). Dentre as demais mulheres, $23.7 \%$ apresentavam vaginose bacteriana e $12.3 \%$ apresentaram vaginose inespecífica

A proporção de isolamento dos principais agentes etiológicos das infecções vaginais varia de acordo com os países em que os estudos são realizados. Nos Estados Unidos da América, Levi et al. (2011) analisaram 431 casos de infecções vaginais e, através da realização de Papanicolao e obtiveram $42,5 \%$ de vaginose bacteriana, 16,2\% de Candida spp e 2,3\% de Trichomonas vaginalis. Na Itália, Casari et al. (2010) através da utilização de oligonucleotídeos específicos para Gardnerella vaginalis, Trichomonas vaginalis e Candida spp detectaram 26,7\% de Gardnerella vaginalis, 12,1\% com Candida spp 21\% de outras bactérias associadas. Na Austrália, McCleland et al. 2006 encontraram Candida spp em 10\% das 1570 amostras de conteúdo vaginal analisados.

$\mathrm{Na}$ Turquia, Buykbayrak et al. (2010) analisaram 460 mulheres, com queixa de desconforto vaginal. De acordo com os autores, 59,8\% apresentaram diagnóstico clínico de vulvovaginites e, 36\% apresentaram confirmação microbiológica. Dessas, 17,4\% apresentaram Candida spp e 10,2\% Gardnerella vaginalis. Esses dados fizeram com que esse autor sugerisse que o diagnóstico laboratorial é insuficiente para confirmação de infecções vaginais. No entanto, o baixo número de isolamento pode ser atribuído às técnicas utilizadas no estudo. 
Esta variação na proporção de isolamentos pode estar associada aos diferentes hábitos de vida, adotados pelas mulheres ao redor do mundo e às diferentes técnicas seguidas pelos laboratórios para realização das análises.

De acordo com Masata et al. (2010) o exame microscópico do material clínico corado pelo método de Gram é o "gold standard" para o diagnóstico do agente causador das infecções vaginais, por ser um método rápido. No presente estudo, essa ferramenta apresentou $75 \%$ de especificidade para o diagnóstico de leveduras, corroborando com essa observação. Essa especificidade associada aos sinais e sintomas clínicos pode ser extremamente útil para detectar não só a presença de Candida spp, como também detectar plurietiologias, como a associação entre leveduras e bactérias.

A coloração do esfregaço pelo método de Gram não substitui a realização da cultura, pois esta apresenta maior acurácia para o diagnóstico de candidíase vulvovaginal e é indicada para os casos em que a mulheres apresentam sinais clínicos de CVV, quando, não é possível observar a presença da levedura, no esfregaço corado pelo método de Gram (SOBEL, 2007). Além disso, a realização da cultura possibilita a obtenção de isolados, que poderão ser identificados e, em casos de falha terapêutica, permite a realização de testes de suscetibilidade "in vitro" aos antifúngicos (DAN et al., 2002).

Em nosso estudo, dez por cento das pacientes, com cultura positiva para leveduras apresentaram associação com bactérias, na coloração do esfregaço pelo método de Gram. Dados semelhantes foram obtidos por Hetticarachchi et al. (2010) em que os autores observaram essa associação em $6 \%$ dos isolados. Como as bactérias e os fungos são patógenos oportunistas, para Soll (2006), não há nada de surpreendente no fato de encontrá-los associados, nos locais de infecção. Na maior parte dos casos, não é possível afirmar qual o micro-organismoque foi o responsável pela infecção primária e qual está aproveitando a disponibilidade de nutrientes existente (SOLL, 2006). Contudo, alguns autores, como McClelland et al. (2009), sugerem que algumas bactérias produzem toxinas, que poderiam ser tóxicas para o desenvolvimento fúngico, entretanto, baixos níveis de Interleucina (IL-8) poderiam atenuar a agressividade dos neutrófilos tornando possível a associação fungo/bactéria. 
O equilíbrio entre as bactérias e os fungos, especialmente, Candida spp na microbiota de indivíduos saudáveis tem sido sugerido como responsável por diminuir a colonização de Candida spp e levando ao desenvolvimento da infecção após a realização de tratamentos com antibacterianos, em especial as tetraciclinas. A colonização induzida por medicamentos em locais como boca, vagina e fezes tem sido amplamente reportada na literatura e, acredita-se que são resultantes da diminuição das bactérias que são competidoras por nutrientes e que podem diminuir o crescimento de Candida spp. Acredita-se que as bactérias anaeróbias sejam as principais competidoras. Estudo realizado por Samon et al. (1993), mostraram em que pacientes que receberam doses de antibióticos de largo espectro, houve uma supressão das bactérias anaeróbias e, consequentemente, ocorreu aumento da colonização por Candida spp, após algumas semanas após o fim do tratamento.

A presença de leveduras, em nosso estudo foi significativa. Das 258 mulheres que participaram do estudo, $61.2 \%$ (158/168) apresentaram cultura positiva para leveduras. Na literatura vários estudos corroboram com os nossos achados. No Brasil, Moreira e Paula (2006) obtiveram 63\% de positividade, na cultura, entre as mulheres com sintomas clínicos de candidiase vulvovaginal. Holanda et al. (2007) observaram que $46.7 \%$ das mulheres apresentaram cultura positiva para leveduras. Ainda no Brasil, Correa et al. (2009), observaram que $39 \%$ das mulheres examinadas, em um Hospital em São José do Rio Preto foram positivas para leveduras.

As leveduras do gênero Candida spp podem viver como comensal na cavidade oral, no trato gastrointestinal e no ânus. Em mulheres saudáveis ela pode ser isolada no canal vaginal e na vulva. De acordo com Odds et al.(2010) a porcentagem de pessoas saudáveis colonizadas por Candida spp pode variar de 26 a 34\%. Em estudo realizado por Sobel (1991) foram realizadas coletas de diferentes sítios anatômicos e $56 \%$ dos indivíduos apresentaram colonização oral, $40 \%$ na região vulvovaginal e $24 \%$ na região anal.

No presente estudo, das 162 mulheres que apresentaram cultura positiva para leveduras, $34 \%$ eram mulheres que não apresentavam sintomas de candidiase vulvovaginal. 
De acordo com Sobel (2007), a colonização genital e extragenital pode estar associada a vários fatores fisiológicos, como alto valor de $\mathrm{pH}$ a gravidez, podem contribuir para a elevação da circulação sistêmica ou local de estrogênio, afetando o crescimento e a maturação do epitélio vaginal, que funciona como uma barreira protetora contra a invasão de micro-organismo. Na presença do estrogênio, os receptores, presentes na superfície celular de Candida spp são estimulados, aumentando a aderência e a germinação das leveduras (SPINILLLO et al., 1997). Na pós menopausa, o número de receptores de estrógeno diminui (MARAZZO et al., 2002).

A transformação da Candida spp como colonizante em Candida sintomática também ainda não é totalmente esclarecida

Landers et al. (2004) sugerem que existe uma associação entre o início dos sintomas de CVV e as relações sexuais em cerca de 15\% das mulheres. Barousse et al. (2004) realizaram uma pesquisa com 163 adolescentes, das quais 22\% apresentaram cultura positiva para leveduras. Esses dados parecem reforçar a hipótese de que a colonização vaginal por Candida spp é iniciada durante o inicio das relações sexuais. Em nossos achados corroborando com estas hipóteses, a média de idade das mulheres pertencentes ao grupo das positivas foi maior do que as negativas. Além disso, a idade do grupo das assintomáticas foi de 29,4 anos foi menor do que nos outros dois grupos (CVV e CVVR).

Lima-Neto et al. (2011) sugerem que a deficiência de lectina ligada à manana pode ser um dos principais fatores de susceptibilidade ao desenvolvimento de vaginites por Candida spp.

As causas que levam a CVVR são complexas e pouco compreendidas. Vários mecanismos podem estar associados a essa condição. Nwokolo (2000) e Watson; Calabretto (2009) apontam os seguintes mecanismos como responsáveis pela CVVR: a re-infecção vaginal a partir de uma fonte exógena, por exemplo, do trato gastrointestinal ou de um parceiro infectado e a recidiva vaginal após a erradicação incompleta dos micro-organismos, por tratamento inadequado ou de curta duração. Fidel e Sobel (1996) propuseram que a diminuição da imunidade adquirida da mucosa, bem como os mecanismos de imunidade mediada por células podem predispor a mulher à CVVR. De 
acordo com Barrouse et al., a imunidade inata é considerada como estando diretamente associada a resistência e susceptibilidade da CVV ou da CVVR.

O diagnóstico de Candida spp pode ser realizado através de testes fenotípicos e genotípicos, a partir de cultivo em meios de cultura específicos. Dentre eles, o CHROMagar Candida é um meio cromógeno que permite a identificação presuntiva das leveduras, por conter vários substratos enzimáticos que, hidrolisados pelas hexoaminidases correspondentes, permitem a identificação da levedura de acordo com a pigmentação exibida pela colônia, em um tempo de 24 a 48 horas. O meio utilizado indica colônias verde-claras para $C$. albicans, verde-escuras para $C$. dubliniensis e azuis para C. tropicalis (ARAÚJO et al., 2005).

Araújo et al. 2005, observaram também $88.2 \%$ de concordância entre a coloração verde e a presença de $C$. albicans. Contudo, para algumas espécies não albicans, a sensibilidade do método foi baixa (39.13\%). Este dado pode estar associado ao fato de que as colorações rosa e roxa são exibidas por várias espécies, como $C$. glabrata, C. krusei, C. parapsilosis, C. guilliermondii, apresentam-se dessa forma. Assim sendo, o meio cromogênico deve ser utilizado apenas para obtenção de culturas puras e não como forma de identificação de leveduras do gênero Candida.

Dentre os 84 isolados identificados como C. albicans ou C. dubliniensis, no CHROMagar, 88,9\% apresentaram coloração verde, no meio e, 14 apresentaram características fisiológicas sugestivas de $C$. dubliniensis. Contudo, o recém lançado livro "The yeasts" (KURZTMAN et al., 2011) sugerem que a diferenciação dessas espécies somente é possível através da realização de métodos moleculares. O mesmo ocorre com o complexo $C$. parapsilosis strictu sensu e de algumas leveduras que apresentam características fisiológicas que não permitem diferenciá-las de outras espécies.

Com isso, a adoção de métodos moleculares vem sendo realizadas em vários estudos. As regiões que mais estão sendo utilizadas como alvo dessas pesquisas são as regiões D1/D2 e ITS (FELL et al., 2000; KURTZMAN et al., 2011).

Em 2000, Chen et al.,. compararam a identificação de 401 isolados clínicos através da região ITS com as técnicas tradicionais de identificação e encontraram 99\% de similaridade entre as duas técnicas. Os autores sugerem que, através de técnicas moleculares da região ITS é possível identificar mais de 34 espécies de leveduras. 
Barroza-Estrada et al. (2010) compararam a eficácia de vários métodos tradicionais de identificação com a identificação através da região ITS, em 79 isolados de Candida spp Os autores concluíram que os métodos moleculares foram eficazes para a identificação de $C$. albicans, C. glabrata, C. krusei, mas foi menos eficaz para a identificação de C. tropicalis.

Ciardo et al. (2006) realizaram um estudo comparativo entre a identificação bioquímica tradicional (microcultivo em ágar fubá, "CHROMagar" e "ID32") com o sequenciamento Os autores encontraram 98\% de correlação entre as técnicas, nas 113 amostras ensaiadas.

No presente estudo, para as reações de sequenciamento, utilizou-se "primers" para a região ITS1/ ITS2 e D1/ D2. Na literatura, os primeiros relatos de reações de sequenciamento foram realizados com a região D1/D2. Mannarelli e Kurtzman (1998) realizaram análises da região D1/D2 de catorze espécies de Candida e, conseguiram correlacionar alterações em $C$. dubliniensis que parecem estar diretamente ligadas a exposição previa ao fluconazol.

Estudos comparativos realizados "a posteriore", como Scorzetti et al.,. 2002 entre as identificações pela região ITS e D1/D2 demonstraram que há uma grande variabilidade na região ITS, que é menos sujeita à mutações. Poucas mutações também foram observadas na região D1/D2.

Com isso, a utilização de quatro sequências de "primers" pode aumentar a eficácia do sequenciamento.

Nesse estudo, a realização do sequenciamento resultou em alterações das identificações das espécies. As leveduras que haviam sido presuntivamente identificadas como $C$. dubliniensis, através das provas bioquímicas realizadas, não tiveram a identificação molecular confirmada, ou seja, todas foram identificadas como C. albicans.

Em estudo realizado por Acikgoz et al. (2003), em Singapura, com 300 amostras de $C$. albicans isoladas de pacientes com candidíase vulvovaginal, $C$. dubliniensis foi identificada em apenas um isolado $(0,17 \%)$, por PCR (Reação de polimerase em cadeia). Os primeiros relatos sobre a presença de $C$. dubliniensis foram à mucosa oral de indivíduos imunocomprometidos (MARIANO et al., 2003) e, aparentemente, esse 
quadro mantém-se, já que é bastante incomum a presença dessa levedura em outros sítios anatômicos.

Estudos apontam que cerca de $80 \%$, de todas as leveduras isoladas na mucosa vaginal são C. albicans (HOLLAND et al., 2003). De fato, em neste estudo, C. albicans esteve amplamente distribuída na população estudada, no grupo das CVV, com 70\% de frequência e nos grupos das assintomáticas e CVVR, com 44 e 41\%, respectivamente.

Uma provável justificativa para o alto índice de Candida albicans na mucosa de mulheres assintomáticas seria a presença desta espécie no trato gastrointestinal que a partir dessa fonte endógena a levedura se disseminaria (CALDERON et al., 2003).

Soll et al. (1991) sugerem que, no início da infecção por Candida spp, na cavidade oral de pacientes portadores de HIV existe a possibilidade de uma cepa comensal ser substituída por cepas geneticamente mais uniformes, com maior capacidade de produzir infecção.

As espécies de Candida não albicans vêm mudando o panorama clínico, apresentando-se como patógeno, especialmente pela seleção de espécies mais resistentes aos antifúngicos (NYIRJISY, 2008).

Ao realizar-se uma comparação das quatro espécies mais frequentes com os trabalhos encontrados na literatura percebeu-se que há boa concordância entre eles. Richter et al. (2005), nos EUA, em estudo realizado em 593 amostras, encontraram 420 C. albicans, 112 C. glabrata, 30 C. parapsilosis, 12 C. tropicalis e, o restante, das demais espécies. Na Varsóvia, Sojakova et al. (2004), encontraram 87,6\% de C. albicans, 6,2\% de C. glabrata e 2,2\% de C. krusei.

No presente estudo, as espécies de Candida não albicans representaram 49\% de todos os isolamentos. Esse índice foi bastante significativo, pois, quando comparamos com outros estudos realizados no Brasil, como o realizado por Holanda et al. (2005) que encontraram 69\% de C. albicans e 31\% de C. não albicans e de Correa et al. (2009), que isolaram $87 \%$ de C. albicans e $13 \%$ das demais espécies. Vale ressaltar que o nosso estudo foi realizado com diferentes grupos de mulheres (assintomáticas, com CVV e com CVVR) e, a porcentagem de ocorrência de espécies não albicans foi maior nos grupos das assintomáticas e das CVVR $(55.6 \%$ e 58.82\%, respectivamente). 
Entre as espécies não albicans, o complexo $C$. parapsilosis foi mais isolado, com $15 \%$ de isolamento. Ao se realizar uma análise por grupo amostral, esta espécie foi mais frequente no grupo proveniente de mulheres portadoras assintomáticas.

De acordo com dados da literatura, a porcentagem de isolamento de $C$. parapsilosis, em secreção vaginal é baixa. Contudo, Nyirjisy 2008 isolou C. parapsilosis em $8.5 \%$ das amostras de secreção vaginal. Os autores sugerem que essa espécie pode ser considerada como um colonizador, transitório na vagina. A mesma opinião é compartilhada por Trofa et al. (2008). Auler et al. (2009) sugerem que essa levedura pode estar associada a utilização de método contraceptivo, como Dispositivo Intrauterino (DIU), que favorece a formação de biofilmes e dificulta o tratamento das infecções por leveduras.

Desde a década passada, a incidência de $C$. parapsilosis vem aumentando drasticamente. Vários estudos indicam que a espécie tem sido considerada como o segundo patógeno mais frequentemente isolado em vários sítios anatômicos, como em sepses, em neonatos. Em 2005, C. parapsilosis foi separada em três grupos: $C$. parapsilosis, C. metapsilosis e C. orthopsilosis (LOCKHART et al., 2008; TAVANTI et al., 2005).

Um fato interessante foi a detecção de dois isolados de C. metapsilosis que foram isolados de mulheres mais velhas e que apresentaram episódios de recorrência. De acordo com Lockhart et al. (2008), essa espécie tem sido isolada em abscessos, líquido ascitico, fluído de lavado broncoalveolar e em fluídos de articulações.

$\mathrm{Na}$ literatura há poucos trabalhos que indicam a incidência do complexo $C$. parapsilosis em amostras de secreção vaginal. Britto et al. (2006) relatam que, entre 80 isolados de hemocultura, identificados como $C$. parapsilosis, 16 foram $C$. orthopsilosis e 4 foram $C$. metapsilosis, o que mostra que essas espécies podem estar presentes entre as identificadas como C. parapsilosis. Na Malásia, Tay et al. (2009) isolaram $C$. metapsilosis em 4,8\% das amostras de $C$. parapsilosis oriundas de hemocultura.

Ao realizarmos uma comparação entre as espécies e o grupo amostral, observamos que o complexo $C$. parapsilosis foi isolado nos três grupos estudados.

A segunda espécie não albicans mais frequente foi $C$. glabrata. Poucos ensaios clínicos têm sido realizados no sentido de esclarecer a fisiopatologia da candidiase 
vulvovaginal por essa espécie. Fidel et al. (2007), sugerem que a alta frequência de isolamento de $C$. glabrata pode ser reflexo de um aumento de conscientização da importância da realização da cultura, ou, se este fato pode estar relacionado com o aumento da utilização de terapias de antifúngicos de longa duração, tanto por via tópica, como os regimes de tratamento orais, principalmente com drogas azólicas.

De acordo com Vermitsky et al. (2008), os fatores que predispõem a vaginite por C. glabrata são: idade, condições médicas subjacentes, como "diabetes mellitus" não controlada e uso de duchas vaginais podem contribuir para o aumento dessa incidência. Em nosso estudo, ao distribuirmos as espécies entre diferentes faixas etárias verificouse que houve um aumento nos percentuais de espécies não-albicans em mulheres mais velhas.

Embora, nenhum estudo em larga escala tenha sido realizado, os sintomas apresentados por mulheres com C. glabrata pode ser distinto dos sintomas apresentados por mulheres portadoras de outras espécies de leveduras. Geiger et al. (1995) relataram que há diferenças sutis nos sintomas apresentados por essas mulheres. Após a avaliação de 80 mulheres com candidiase, os autores observaram que as portadoras de C. glabrata apresentavam menos leucorréia e prurido que as demais. Contudo, a queixa de ardor era mais frequente.

Em nosso estudo ao compararmos a frequência de isolamento de leveduras com o grupo amostral percebemos que $C$. glabrata não esteve presente nas mulheres que apresentavam sintomas primários de vulvovaginite, estando apenas no grupo das assintomáticas e das que apresentavam recorrência. Esse fato talvez seja atribuído à baixa intensidade dos sintomas provocados por $C$. glabrata, que pode refletir a ausência da formação de hifa pelos blastoconídeos por essa espécie, já que nas extremidades das hifas e do tubo germinativo estão presentes as enzimas proteolíticas, que exercem um papel de alérgeno (SOBEL, 2007).

O isolamento de quatro $C$. haemulonii, em conteúdo vaginal foi bastante surpreendente. De acordo com Kutzman et al. 2011, esta espécie de levedura pode ser considerada como pertencente a mesma família da Clavispora (Candida) lusitaniae. $\mathrm{Na}$ literatura, há relatos dessa espécie em ambiente marinho, já que essa é altamente tolerante a grandes concentrações de cloreto de sódio. Poucos estudos relatam a 
presença de C. haemulonii em isolados clínicos. Sugita et al. (2006) isolaram uma amostra de $C$. haemulonii em paciente com sepse. Testes de sensibilidade "in vitro" mostraram que o isolado era resistente a anfotericina $\mathrm{B}$ e ao fluconazol.

Outro fator que despertou a atenção foi presença de Rhodotorula spp e de Trichosporon spp entre casos sintomáticos de CVV.

Tuon e Costa (2003) chamam a atenção para o fato de que Rhodotorula spp está surgindo como um patógeneo emergente oportunista, particularmente em indivíduos imunocomprometidos. Muitos casos de fungemia associadas com uso de cateteres, endocardites, peritonites, meningites e endoftalmites podem ser causadas por essa levedura. A taxa de mortalidade pode chegar a $12,6 \%$.

Outro patógeno oportunista importante é o gênero Trichosporon spp. As espécies denominadas anteriormente como $T$. beigelli e $T$. cutaneum foram reclassificadas como T. asahii. Essa espécie é a mais importante do gênero Trichosporon e pode causar granulocitopenia, tumores malignos e infecções de pelos pubianos (YANG et al., 2008). De acordo com Miceli et al. (2011), esse gênero é a segunda causa mais freqüente de fungemia, e apresentam resistência a anfotericina $B$ e as equinocandinas.

Esses dados refletem a importância da realização da cultura e a identificação das leveduras presentes no conteúdo vaginal.

O primeiro passo para que ocorra a infecção é a colonização da mucosa. Alguns autores descrevem que, a capacidade de Candida albicans produzir tubo germinativo, torna esta espécie mais invasiva do que as outras espécies, o que também poderia explicar a alta incidência da mesma (FERRER, 2000; FOSTER, 2002). De acordo com Felk et al. 2002, isolados de $C$. albicans que não produzem hifas são menos virulentos do que os isolados que são produtores das enzimas.

Depois do processo inicial, ocorre a adesão da levedura (DE BERNARDIS et al., 2001). Essa fase é mediada por fatores de virulência, expressos pelos microorganismos. Dentre os quais, a produção de proteinases e fosfolipases são as mais estudadas.

No presente estudo, verificou-se que $81 \%$ das amostras foram produtoras de proteinase. Ao fazermos uma comparação com outros trabalhos descritos na literatura, como o de Ribeiro et al. (2004), os nossos resultados foram menores, já que naquele 
estudo a produção da proteinase foi observada em $100 \%$ dos isolados de Candida spp provenientes de secreção vaginal. Maffei et al. (1997) também observaram uma produção de proteinase de $100 \%$ das amostras isoladas de secreção vaginal, de pacientes gestantes.

Embora o papel exercido pelas proteinases "in vivo" ainda não esteja totalmente estabelecido, e alguns autores questionem a ação desta enzima como um fator de virulência, estudos realizados com amostras de Candida albicans isoladas da vagina de mulheres assintomáticas podem ser utilizadas como controle para o estudo das mesmas. De Bernardis et al. (2001), verificaram que amostras isoladas de pacientes assintomáticas apresentam uma diminuição ou ausência da secreção de proteinase "in vitro".

De acordo com Fidel e Sobel (1996), ao se inocular em animais de experimentação, amostras de Candida spp provenientes de portadoras assintomáticas, esses mostraram serem menos virulentos do que as amostras provenientes de pacientes sintomáticas. Com isto, isolados que produzem altas concentrações de proteinases, realmente podem influenciar na susceptibilidade dos hospedeiros às vaginites (FIDEL; SOBEL, 1996).

No presente estudo, ao realizar-se a comparação da produção de proteinase, por grupo amostral, não foram observadas diferenças estatisticamente significativas entre os grupos estudados.

Esse fato pode reforçar a hipótese de que a proteinase é utilizada pelos microorganismos como um fator de sobrevivência, ou seja, para que o micro-organismo se adapte aos diferentes nichos ecológicos, retirando nutrientes necessários para a sua sobrevivência (BROWN et al., 2007) e não como um fator de agressão ao hospedeiro. Além disso, a microbiota vaginal é um ambiente que propicia a expressão de proteinase. $\mathrm{O} \mathrm{pH}$ da vagina que varia de 2.5 a 5.0, é rico em proteínas e peptídeos que favorecem a expressão dos genes SAPs, especialmente a indução e expressão da SAPs 2 (CASSONE et al., 2007; CHAFFIN et al., 2008).

Assim como as proteinases, alguns autores relatam que as fosfolipases poderiam participar dos processos de patogenicidade dos micro-organismos. A atividade da fosfolipase, como um fator de virulência tem sido estudada não só em 
fungos, como também em amostras de bactérias e protozoários (IBRAHIM et al., 1995; KANTARCIOGLU; ŸUCEL, 2001; NAGLIK et al., 2003a).

$\mathrm{Na}$ literatura, a expressão de fosfolipase é controversa. Alguns autores sugerem que a expressão de fosfolipase é maior em amostras oriundas de infecções sistêmicas, enquanto outros sugerem que a presença de fosfolipase é maior entre os isolados provenientes de infecções superficiais. Penha et al. (2000) descreve a produção de fosfolipase em $83,3 \%$ dos isolados de Candida spp provenientes da cavidade oral. Kantarcioglu e Ÿucel (2001) verificaram que 62,1\% das leveduras isoladas de diferentes sítios anatômicos foram produtoras de fosfolipase.

No presente estudo apenas $39 \%$ das amostras apresentaram atividade fosfolipásica. As espécies que mais produziram fosfolipase foram C. albicans (53,7\%), C. tropicalis (44.4\%) e C. parapsilosis (13.7\%). Não foram observadas diferenças entre a atividade fosfolipásica dos isolados de $C$. albicans e $C$. tropicalis. Porém, $C$. albicans foi mais produtora de fosfolipase do que $C$. parapsilosis.

De acordo com Brown et al. (2007) Candida albicans é a espécie que possui a capacidade de expressar uma maior quantidade de genes que induzem a produção de enzimas como, produção de catalase, superóxido dismutase e proteínas de choque térmico (HPW 90) que seriam capazes de provocar um maior estresse oxidativo das células do sistema imunológico.

Em um estudo realizado por Ombrella et al. (2008), os autores pesquisaram a expressão de proteinase e fosfolipase em amostras de Candida spp provenientes da secreção vaginal de mulheres que possuíam a flora vaginal $>4.5$ e $<4.5$. A expressão de fosfolipase não foi diferente entre os grupos, porém, a atividade de proteinase foi maior entre as mulheres que apresentavam $\mathrm{pH}>4.5$ (96,2\% 61,5\%). Esse fato demonstra que a atividade de $\mathrm{pH}$ exerce um papel fundamental na expressão de proteinase. Já a expressão de fosfolipase é contraditória, porém, é fato de que essa atividade está diretamente relacionada ao gene PLB1, que tem sua expressão regulada por fatores nutricionais, meio ambiente (temperatura e $\mathrm{pH}$ ) e a fase de crescimento da leveduras, Aparentemente, a expressão do gene PLB1 seria regulada pelos mesmos fatores que regulam a morfologia da levedura (OMBRELLA et al., 2008). 
Quando foi realizada a comparação por grupo amostral, observou-se que as amostras isoladas do grupo das assintomáticas foram as que menos produziram fosfolipase. Esse fato talvez esteja relacionado com a ideia de Cassone et al. (2007) que para a levedura se manter como um comensal é necessário que ocorra um equilíbrio entre as respostas inata e adaptativa que restrinjem o crescimento fúngico e neutralizem sua virulência. De acordo com os autores, esse é o estágio inicial (estágio 1) relacionado com a transformação da levedura comensal em patogênica. No estágio dois, a integridade da membrana epitelial, os mecanismos imunorregulatórios e tolerância local ao fungo são componentes importantes para a manutenção desse equilíbrio. A doença (estágio 3) ocorre quando há um excesso de fatores de virulência, provocado por uma maior carga de micro-organismos, seja pela quebra da integridade da célula epitelial ou através da quebra da tolerância ao fungo. Essa quebra pode ocorrer, em algumas mulheres, por mecanismos ainda não totalmente estabelecidos, porém, parecem estar relacionados a fatores genéticos.

Nos últimos anos, com o aumento das vulvovaginites causadas principalmente por espécies não-albicans, a identificação de gênero e espécie das leveduras, bem como um estudo mais detalhado de sensibilidade "in vitro" frente às drogas antifúngicas disponíveis para o tratamento, tornou-se importante para a escolha terapêutica, especialmente em casos de recorrência (CUENCA-ESTRELLA, 2000).

$\mathrm{Na}$ literatura nacional e internacional há diversos trabalhos de sensibilidade aos antifúngicos realizados em centros de pesquisa (CANDIDO et al., 1999; COSTA et al., 2004; RIBEIRO et al., 2000; SOJAKOVA et al., 2004); porém, estes testes não são realizados rotineiramente em laboratórios e hospitais, onde a maior parte das pacientes recebe tratamento empírico (RITCHER et al., 2005).

O sucesso terapêutico depende de vários fatores, como a resposta imunológica do paciente (CONTI et al., 1999; SANGLARD; ODDS, 2002); os níveis de concentração da droga, no sangue; quebra de proteína (CONTI et al., 1999); penetração inadequada da droga ao local de infecção (GHANNOUM; RICE, 1999); interação com outras drogas (REX et al., 1997); e em casos de candidíase vulvovaginal, a composição da microbiota vaginal (SOBEL et al., 2003b). Os fatores relacionados aos micro-organismos, como a produção de toxinas e outros fatores de virulência, como produção de fosfolipases, em 
amostras de Candida spp têm um impacto significante na probabilidade de sucesso terapêutico (REX et al., 1997).

A resistência clínica pode ser definida como a falha de um agente antifúngico para curar uma infecção ou pode estar relacionada à diminuição da susceptibilidade dos isolados clínicos, frente aos antimicóticos (ESPINEL-INGROFF, 2006). A resistência de Candida spp aos derivados azólicos é o tipo mais prevalente de resistência antifúngica. De acordo Mardh et al. (2010), 7.5\% dos isolados de Candida spp provenientes de secreção vaginal podem apresentar resistência "in vitro" a pelo menos um antifúngico.

$\mathrm{O}$ aparecimento de amostras resistentes aos antifúngicos mais utilizados na clinica médica pode estar associado à mutações na síntese da $1,3 \beta$ glucana, principal componente da parede celular dos fungos (PFALLER et al., 2004). De acordo com Katiyar et al. (2006), as amostras que apresentaram resistência "in vitro" apresentaram alterações nos genes Gsc1 (1,3 $\beta$ glucana sintetase 1), em $C$. albicans e no análogo Fks2, em C. glabrata.

De acordo com Sanglard e Odds (2002) a resistência pode ser resultado de: a) um aumento no conteúdo celular do citocromo P450, nomeado CYP51A1, envolvidos na 14- $\alpha$-demetilação de lanosterol, (b) a diminuição da afinidade para CYP51A1 azóis, (c) uma falha das células de acumular estes agentes; (d) uma via de biossíntese do ergosterol alteradas decorrentes de inativação da 5,6-desaturase do ergosterol.

Nos anos de 1990, foi desenvolvido o "Etest", um "kit" comercial que permite a determinação da concentração inibitória mínima (CIM) das drogas (CANDIDO et al., 1999). O "Etest" tem a vantagem de ser de fácil execução, porém, uma boa reprodutibilidade depende de uma padronização do tamanho do inóculo, da temperatura e do tempo de incubação (VAN ELDERE et al., 1996).

Na literatura, vários estudos utilizam o "Etest" para testar a sensibilidade "in vitro" aos antifúngicos. No presente estudo, utilizou-se essa ferramenta para testar a sensibilidade das leveduras a cinco antifúngicos mais utilizados em casos de candidíase vulvovaginal.

Frente a anfotericina B, $91,3 \%$ dos isolados foram sensíveis e $8,7 \%$ foram considerados resistentes. Fleck et al. (2007), na Alemanha, encontraram 96,3\% de 
sensibilidade à anfotericina B. Kiraz et al. (2010), obtiveram 100\% de sensibilidade a esse fármaco.

Realizamos, ainda, uma comparação dos valores de CIM do nosso estudo, com o estudo realizado por Pfaller et al. (2004) e, observamos que, os autores tiveram uma variação de CIM semelhante a nossa para $C$. albicans $(0,03-4 \mu \mathrm{g} / \mathrm{mL})$, uma menor variação de CIM para $C$. glabrata e $C$. parapsilosis $(0,003-16 \sim 324 \mu \mathrm{g} / \mathrm{mL})$; para $C$. tropicalis e $C$. krusei, uma variação de CIM maior do que a observada em nosso estudo $(0,03-16 / 324 \mu \mathrm{g} / \mathrm{mL})$.

Para o cetoconazol, a porcentagem de amostras sensíveis foi de $96,3 \%$. Apenas um isolado de $C$. albicans foi resistente a esse antifúngico. Em estudo realizado por Cartledge et al. (1999), os autores realizaram a sensibilidade "in vitro" de isolados de Candida não albicans provenientes de orofaringe e, observaram que todos os isolados de C. glabrata foram resistentes "in vitro" e "in vivo" ao cetoconazol. Em nosso estudo, nem todas as amostras de $C$. glabrata foram resistentes a esse antifúngico, e, uma sensibilidade diminuída foi observada em amostras de $C$. famata, $C$. kefyr e em $C$. haemulonii.

Frente ao fluconazol, o índice de sensibilidade foi de $94,9 \%$. Os isolados que foram resistentes foram C. albicans (2), C. glabrata (2), C. haemulonii (1), C. famata (1) e C. kefyr e não Candida (que inclui Trichosporon spp e Rhodotorula spp). Todos os isolados de C. krusei foram sensíveis a esse antifúngico.

$\mathrm{Na}$ literatura, vários estudos que realizaram a sensibilidade ao fluconazol. Bulmer et al. (1999), nas Filipinas tiveram 94\% de isolados sensíveis, 5\% de SDD e $1 \%$ resistente; Mohanty et al. (2007), em Nova Delhi encontraram 30\% de Candida spp consideradas sensibilidade dose dependente. Cardona-Castro et al. (2002), na Colombia, não observaram isolados resistentes ao fluconazol, em amostras provenientes de hemocultura. Porém, Shahid e Sobel (2008) chamam a atenção para o fato de que um longo tempo de terapia profilática com fluconazol pode levar a seleção de espécies resistentes a esse fármaco.

Em relação ao itraconazol, a resistência foi observada em $12,7 \%$ dos isolados e a sensibilidade dose dependente, em 11,1\%. Essa diminuição da sensibilidade ao 
itraconazol foi observada em todas as espécies. Uma pesquisa na literatura mostrou que esse não é um dado isolado.

Liu et al. (2008), na Correia, obtiveram 19,1\% de isolados resistentes; Pfaller et al. (1996) relata uma grande quantidade de isolados de $C$. krusei e $C$. parapsilosis resistentes a esse antifúngico. Sojakova et al. (2004) relata que 18,5\% das amostras foram resistentes ao itraconazol. Martin-Mazuelos et al. (1999) relata que 61,4\% das amostras foram sensíveis ao itraconazol, indicando que a diminuição da sensibilidade ao itraconazol não é um fato novo, mas que merece grande atenção.

O voriconazol é um triazol de segunda geração, derivado do fluconazol, porém, com um espectro de ação maior do que o fluconazol. Em nosso estudo, 95,7\% dos isolados foram considerados sensíveis a esse antifúngico. De acordo com Pernán et al. (2006), o voriconazol possui uma boa atividade "in vitro" sobre as leveduras do gênero Candida, inclusive aquelas que apresentam menor sensibilidade ao fluconazol e a anfotericina B. Os autores sugerem, inclusive, que parece não haver resistência cruzada entre fluconazol e voriconazol. Esse fato poderia auxiliar na adoção de voriconazol, em casos de resistência ao fluconazol. Um impediente para a prescrição desse fármaco é o alto custo do tratamento.

Pfaller at al. (2007) chamaram a atenção para o surgimento de resistência cruzada entre os azólicos "in vitro". A diminuição da susceptibilidade ao fluconazol poderia preceder a resistência ao voriconazol. No presente estudo, praticamente todos os isolados resistentes ao fluconazol foram resistentes ao voriconazol (5.6\%).

As equinocandinas (CEs), como caspofungina, são antimicrobianos lipopeptídeos que inibem a síntese da parede celular dos bolores e das leveduras, como Candida albicans e Aspergillus fumigatus. Nagappan et al. (2010) ressaltam a importância da utilização da caspofungina, como alternativa para tratamento de isolados resistentes ao fluconazol.

A não sensibilidade à caspofungina foi observada em $8.2 \%$ dos nossos isolados. Espinel-Ingroff et al. (2010) realizaram um estudo comparando a sensibilidade "in vitro" as equinocandinas, através do "Etest" e da microdiluição. Os autores concluíram que não houve concordância entre os resultados obtidos pelo "Etest" para as espécies $C$. parapsilosis $(54,4 \%)$ e C. guilliermondii (82,4\%), mas, para as espécies C. albicans, $C$. 
glabrata, $C$. krusei e C. tropicalis a concordância foi bastante satisfatória, variando de 87.9 a $100 \%$.

De acordo com Pfaller et al. (2004), a diminuição da sensibilidade à caspofungina pode estar associada a mudanças na síntese de $\beta$ glucana. Em um estudo realizado pelo autor, apenas $1 \%$ dos isolados foram resistentes a essa droga. Para Katiyar et al. (2006), essa diminuição da sensibilidade está associada a mutação do gene F641Y, em C. albicans e um análogo RESY641 foi identificado em isolados de Fusarium spp, C. glabrata e C. guilliermondii.

Quando realizamos uma comparação por espécie, C. glabrata foi a que apresentou menor sensibilidade a esse antifúngico, seguida por $C$. haemulonii, pelo "Etest". De acordo com Ostrosky-Zeichner (2003), a resistência a anfotericina B, entre os isolados de C. parapsilosis é de 2 a $3 \%$. Em nosso estudo, essa resistência foi vista em um isolado, que representava $4,2 \%$ do total de $C$. parapsilosis estudadas.

As amostras que foram consideradas resistentes ou sensibilidade dose dependente aos antifúngicos anfotericina $B$, itraconazol e fluconazol, pelo "Etest" foram submetidas a ensaios de microdiluição (EUCAST EDef7.1 e CLSI M27S3). O método do CLSIM27S3 é considerado "gold standard" para a detecção de resistência.

Os dez isolados que haviam sido considerados resistentes a anfotericina B pela técnica do "Etest" foram selecionados para a realização das técnicas de microdiluição (EUCAST Edef7.1 e CLSIM27S3) foram sensíveis a esse antifúngico.

Através dos dados obtidos pelo método de microdiluição proposto pelo CLSIM27S3, 57,6\% que haviam sido considerados SDD, no Etest foram sensíveis, na microdiluição; 3 foram considerados SDD no Eucast e sensíveis pelo CLSI.

Dos isolados conderados SDD, 3 foram S, nos dois métodos; 3 foram SDD no Eucast e S no CLSI; 3 foram SDD nos três métodos; um isolado foi resistente, nos três métodos.

Dos doze isolados haviam sido considerados resistentes ao fluconazol, pelo "Etest", seis foram sensíveis; dois foram resistentes no CLSI e R no Eucast e 4 foram SDD, nos três métodos.

Pfaller et al. (2006) encontraram valores maiores de CIM pelo "Etest" para C. krusei ATCC 6258, em ensaios comparativos com a microdiluição e, atribui essa 
diferença a composição dos meios de cultura. Cantón et al. (2006) também descrevem que o CIM para o fluconazol foi maior nos ensaios em ágar do que no de referência.

Outro fato que merece atenção é que seis dos oito isolados considerados resistentes ou SDD no "Etest" ao fluconazol foram considerados como resistentes, no EUCAST EDef7.1. Corroborando com os nossos achados, Cuenca-Estrella et al. (2005) testou a sensibilidade "in vitro" do EUCAST EDef7.1 com vários métodos comerciais e concluíram que melhores resultados foram obtidos entre o EUCAST e o "Etest".

Pelo método proposto pelo EUCAST Edef7.1, seis isolados foram considerados como resistentes ao fluconazol. Desses, quatro haviam sido considerados como SDD, pelo "Etest" e pela microdiluição (CLSIM27S3).

Em estudo realizado por Pfaller et al. (2011), comparando-se a sensibilidade de 1056 isolados de Candida spp, os autores concluíram que, para o fluconazol, houve discordância entre os o Eucast e o CLSI. Os valores de CIM foram maiores no EUCAST EDef7.1 Para o flucoanzol a corrrelação entre os dois métodos foi de $98,6 \%$.

Arendrup et al. (2010) realizou a comparação entre os vários métodos de sensibilidade para a detecção da susceptibilidade das equinocandinas e, de acordo com os autores, os métodos que foram mais similares foram CLSI, EUCAST e "Etest".

Cuenca-Estrella et al. (2010) realizaram um estudo comparativo entre os dois métodos de microdiluição e outros métodos comerciais, dentre eles, o "Etest". Nesse estudo, os autores encontraram 98,4\% de concordância entre o "Etest" e o EUCAST, para a anfotericina B e de $96,4 \%$ para o fluconazol. Entre o "Etest" e o CLSI, os resultados foram de $97,4 \%$ para a anfotericina $B$ e de $95,6 \%$ para o fluconazol.

Ao final desses experimentos, tendo os ensaios de microdiluição (CLSIM27S3), como referência, conclui-se que quatro isolados do grupo das CVVR foram SDD ao fluconazol foram pertencentes ao grupo das CVVR. Frente ao fluconazol, seis isolados foram considerados SDD.

Seis isolados $(3.7 \%)$ foram considerados como sensibilidade dose dependente (SDD) e nenhum isolado foi resistente ao itraconazol. Frente ao fluconazol, quatro isolados $(2,4 \%)$ foram considerados SDD, pelo referido método. No Brasil, Antunes et al. (2004), através da microdiluição, encontraram $14,1 \%$ de isolados de Candida spp considerados SDD. 
De acordo com Pfaller et al. (2003), vários trabalhos descrevem que há boa reprodutibilidade entre o "Etest" e o método "gold standard", porém, quando se realiza uma análise em separado, das espécies não albicans, como $C$. glabrata, verifica-se que há uma diferença de $68 \%$ entre eles. Essa diferença está, principalmente, entre os isolados classificados como S ou SDD. Os autores chamam a atenção para o fato de que esses isolados, considerados SDD, podem adquirir resistência rápida aos antifúngicos.

Fleck et al. (2007) relatam que $96,3 \%$ dos isolados foram considerados $\mathrm{S}$ a anfotericina $\mathrm{B}$, com CIM de $1 \mathrm{mg} / \mathrm{L}$. Os maiores valores de CIM foram vistos nos isolados de $C$. glabrata e $C$. krusei. Os autores detectaram resistência ao fluconazol em $2,5 \%$ dos isolados e a sensibilidade dependente da dose foi vista em $7,1 \%$. Esses dados corroboram com os resulatdos de nossa pesquisa.

Uma amostra de C. albicans (1\% de todos os isolados) foi considerada SDD ao itraconazol, o que demonstra que isolados dessa espécie ainda apresentam boa sensibilidade "in vitro" aos antifúngicos. Esse fato corrobora com a literatura que diz que a resistência, em C. albicans, é menor que 1\% (GYGAX et al., 2008). Além disso, Calvet et al. (1997), através de modelo animal, concluíram que a resistência, em $C$. albicans pode ser reversível.

Uma amostra de $C$. parapsilosis foiconsideradas SDD ao itraconazol. Trofa et al. (2008) relatam que $1,5 \%$ dos isolados de C. parapsilosis podem apresentar sensibilidade diminuída aos antifúngicos, em ensaios "in vitro".

Lima et al. (2008) chamam a atenção para o fato de que em uma mulher, HIV positiva, com onicomicose por Candida albicans e $C$. tropicalis, com resultado resistente "in vitro", não apresentou resposta clínica aos antifúngicos administrados. De acordo com os autores, essa resistência teria sido provocada pela prévia exposição a fluconazol, em um outro momento, em que a mulher havia manifestado candidíase oral.

A maior parte dos isolados considerados SDD ao itraconazol e ao fluconazol foram de C. glabrata. Borst et al. (2005) chama atenção ao fato de que, essas amostras de C. glabrata, consideradas SDD "in vitro" podem rapidamente adquirir uma resistência quando expostas aos azólicos. Essa observação é importantíssima, pois, em nosso País, não é rotineiro a realização de cultura e, em menor escala ainda, a realização de 
testes de sensibilidade, em casos de candidíase vulvovaginal, o que pode agravar esse quadro.

Outro fato que merece destaque é que um isolado de $C$. glabrata que apresentou sensibilidade reduzida aos dois antifúngicos fora proveniente de uma mulher assintomática, que, não havia recebido antifúngicos previamente. Esse fato pode ser indicativo do mecanismo de resistência intrínseca desse isolado às drogas antifúngicas.

Roetzer et al. (2010) sugerem que o desenvolvimento dessa resistência, prévia. aos antifúngicos poderia estar associada aos mecanismos de sobrevivência da levedura às substâncias tóxicas presentes na microbiota da mucosa vaginal. De acordo com os autores, C. glabrata poderia permanecer como colonizante em consequência do local escolhido para a colonização, já que é mais frequente isolar essa levedura na superfície da mucosa, agregada a biofilmes, ou em locais onde há uma escassez de nutrientes, pressão osmótica diminuída e em locais em que há outros micro-organismos e onde os mecanismos de proteção dos hospedeiros estão ativos, o que torna a espécie mais resistente.

A outra amostra de $C$. glabrata que foi considerada SDD ao fluconazol fora considerada resistente nos três outros métodos e foi isolada do conteúdo vaginal de uma mulher que de acordo com o protocolo clinico, não apresentava resposta clínica satisfatória a nenhum dos tratamentos previamente descritos (fluconazol, itraconazol e voriconazol).

As demais leveduras SDD ao itraconazol foram C. guilliermondii e Trichosporon spp. Yang et al. (2008) já chamavam a atenção para o fato de que as espécies de Trichosporon poderiam ser menos sensíveis aos antifúngicos.

Em um estudo realizado por Richter et al., (2005), em isolados provenientes de secreção vaginal, foi identificado a presença de um Trichosporon spp que foi resistente ao itraconazol. Em nosso estudo, dos três isolados, apenas apresentou sensibilidade dependente da dose a esse antifúngico. Em relação ao fluconazol, nenhum isolado foi considerado resistente "in vitro"

Os resultados obtidos revelam a importância da realização dos ensaios de sensibilidade "in vitro" aos antifúngicos, sejam pelo método "gold standard" seja pelo Etest, pois, através deles, é possível a prévia detecção da resistência "in vitro". Outro 
fato que merece destaque é o isolamento de leveduras, SDD, no grupo das assintomáticas. Apesar de não ser possível acompanhar essas mulheres, ao longo de suas vidas, esses isolados podem representar um problema grave, no futuro, pois, uma mudança na fisiologia da microbiota, provocada por alterações hormonais, principalmente, em casos de gravidez, quando essas cepas poderiam multiplicar-se, levando ao desenvolvimento de CVV.

Em caso de tratamento, essas cepas poderiam representar uma falha terapêutica, ou ainda, essas poderiam não apresentar sintomas exacerbados, de infecção, porém, poderiam colonizar a cavidade oral de recém-nascidos, o que poderia levar ao desenvolvimento de uma sepse neonatal.

A realização da cariotipagem eletroforética permite a separação de fragmentos de cromossomos de leveduras, em gel (BORIOLLO et al., 2009), o que possibilita a comparação entre as cepas e avaliação dos seus subtipos, através da avaliação visual dos diferentes números de bandas apresentadas e permite a análise cladística dessas bandas, através da construção de dendogramas. Esses, possibilitam a verificação da similaridade existente entre os isolados (CARRIÇO et al., 2005).

Em nosso estudo, selecionamos 61 isolados que apresentavam algumas características que os distinguia dos demais, como: a baixa produção de uma enzima ou a sensibilidade diminuída aos antifúngicos, para comparar com os perfis apresentados por outras leveduras. A análise adotada foi a visual e a com auxílio de "software".

Observamos que as amostras de $C$. albicans apresentaram bandas que variaram de $275 \mathrm{~kb}$ a $4100 \mathrm{~kb}$. O número de bandas variou de 4 a 9 , sendo que a maior parte dos isolados apresentou de 6 a 8 bandas. A análise do dendograma mostrou que os isolados de $C$. albicans não estão correlacionados entre si.

Estudo publicado por Merz et al. (1988), mostrou que, de 17 isolados de C. albicans foram encontrados catorze padrões distintos de bandas, corroborando com os nossos achados. Shin et al. (2004), em amostras de quinze pacientes com fungemia, encontraram oito padrões eletroforéticos.

Para C. glabrata, as amostras apresentaram de 8-10 bandas. Porém, com o auxilio de dendograma, não foi possível traçar uma similaridade entre os isolados. 
Khatkat et al., (1992), através de análise visual encontraram 10 padrões de bandas cromossômicas, em dezoito isolados de C. glabrata. Kaufman e Merz (1989) relatam a observância de 8 a 12 bandas, variando de 445 a 3000kb e um total de 22 padrões distintos de bandas, em 33 pacientes.

Os isolados de C. kefyr mostram que houve variação de 300 a $2500 \mathrm{~kb}$ e o número de bandas foi de 5 a 7 . Vasquez et al. (1993) relatam que um isolado de $C$. kefyr avaliado apresentou sete bandas cromossômicas. Em nosso estudo não foi possível obervar uma entre as bandas.

Dentre os isolados de $C$. parapsilosis e $C$. tropicalis ocorreram os mesmos fenômenos. Na literatura, Shin et al. (2001), na Coreia, encontraram 25 padrões distintos de bandas, entre amostras de $C$. parapsilosis isoladas de pessoas com fungemia recorrente.

Pelos resultados obtidos não foi possível correlacionar as cepas entre si. De acordo com Vasquez et al. (1993) um melhor resultado poderia ter sido obtido se as amostras tivessem sido tratadas com enzima de restrição (REA), porém, esse tratamento não foi realizado.

Essa falta de correlação, entre os isolados, pode ser por não haver uma origem comum dessas cepas, já que as mulheres estudadas eram de diferentes regiões de São Paulo.

Além disso, acreditamos que, devido às diferentes composições da microbiota vaginal, cada levedura apresente diferentes perfis de cariótipos. E, ao finalizarmos os nossos estudos, podemos concluir que a presença de Candida spp no conteúdo vaginal e o desenvolvimento de infecções é fortemente influenciada mais por mecanismos dos hospedeiros do que pelas próprias características das leveduras.

Outra conclusão importante é que há uma grande dificuldade no tratamento dos casos de CVVR e, isso pode ser gerado por mudanças nos perfis de sensibilidade das amostras, ou pela exposição prévia a antifúngicos, porém, percebemos que, embora essas amostras apresentam-se sensíveis aos antifúngicos 'in vitro", na prática, isso não se reproduz, provavelmente por causa da resposta imunológica dos hospedeiros, ou pela absorção e concentração da droga, que chega à mucosa vaginal. 
Novos ensaios sobre essa biodisponibilidade da droga, aos locais de infecção devem ser realizados.

Além disso, faz-se necessário reforçar a importância da identificação laboratorial dos isolados de Candida spp. Talvez fosse interessante a adoção, pela comunidade médica, a prática de se realizar a cultura, nos casos em que presença de levedura fosse detectada no exame de Papanicolao, principalmente em mulheres gestantes. 
125

6 CONCLUSÃO 
* Os resultados apontam que não há diferença significativa entre as espécies isoladas, nos três grupos. Entre as amostras isoladas no grupo das assintomáticas, as espécies mais frequentes foram C. albicans, C. glabrata, C. parapsilosis e Rhodotorula spp. As espécies mais isoladas no grupo das CVVs foram C. albicans, C. parapsilosis e C. tropicalis. No grupo das CVVR, as quatro espécies mais isoladas foram C. albicans, C. glabrata, C. parapsilosis e C. tropicalis, porém, não foram encontradas C. glabrata no grupo das CVVs;

* A identificação tradicional (morfofisiológica) mostrou-se eficaz para identificar as espécies que são mais frequentes, na mucosa vaginal. Contudo, esses testes não permitiram a identificação de quatro isolados de Candida haemulonii; catorze isolados apresentaram características fenotípicas semelhantes a C. dubliniensis, porém, o sequenciamento mostrou que elas eram $C$. albicans e, dos vinte e quatro isolados identificados como C. parapsilosis, dois foram classificados como $C$. metapsilosis, demonstrando que essas diferenças somente podem ser detectadas através de métodos moleculares, como o sequenciamento;

* Através da técnica de PFGE (cariotipagem em campo pulsado) não foi possível verificar a similaridade entre as espécies de leveduras, de acordo com os grupos estudados;

* Através dos resultados obtidos não foi possível verificar diferenças entre os perfis apresentados pelas leveduras, quanto a frequência, produção de enzimas (proteinase e fosfolipase), perfis cromossômicos, em relação aos grupos amostrais;

* Os ensaios realizados mostram que houve uma boa correlação entre o método de difusão em ágar ("Etest") e os métodos de microdiluição;

* De modo geral, as amostras isoladas do grupo das CVVRs apresentaram menor sensibilidade aos antifúngicos; bem como amostras do grupo das assintomáticas, pelos três métodos (Etest, Eucast e CLSI);

* Observamos, através de nossos estudos que faz-se necessária a realização de exames laboratoriais, como a identificação das leveduras presentes no conteúdo vaginal, mesmo em casos em que a mulher não apresente sintomas clínicos de CVV, no momento da consulta; já que, mesmo as leveduras provenientes de mulheres assintomáticas podem ser resistentes aos antifúngicos usuais. 
F REFERENCIAS 
ACHKAR, J. M.; FRIES, B. C. Candida infections of the genitourinary tract. Clinical Microbiology Reviews, v. 23, n. 2, p. 253-73, 2010.

ACIKGOZ, Z. C.; SANCAK, B.; GAMBERZADE, S.; MISIRLIOGLU, M. Prevalence of Candida dubliniensis among the stored vaginal Candida isolates in a Turkish hospital. Mycoses, v. 47, n. 9-10, p. 393-396, 2004.

ALBERT, T. K.; HANZAWA, H.; LEGTENBERG, Y. I.; DE RUWE, M. J.; VAN DEN HEUVEL, F. A.; COLLART, M. A.; BOELENS, R.; TIMMERS, H. T. Identification of a ubiquitin-protein ligase subunit within the CCR4-NOT transcription repressor complex. The EMBO Journal, v. 21, n. 3, p. 355-364, 2002.

AL-RAWI, N.; KAVANAGH, K. Characterisation of yeasts implicated in vulvovaginal candidosis in Irish women. British Journal of Biomedical Science, v. 56, n. 2, p. 99104, 1999.

AL-SWEIH, N.; AHMAD, S.; KHAN, Z. U.; KHAN, S.; CHANDY, R. Prevalence of Candida dubliniensis among germ tube-positive Candida isolates in a maternity hospital in Kuwait. Mycoses, v. 48, n. 5, p. 347-351, 2005.

ALVES, S. H.; MILAN, E. P.; , SANT'ANA, P. L.; OLIVEIRA, L. O.; SANTURIO, J. M.; COLOMBO, A. L. Hypertonic sabouraud broth as a simple and powerful test for Candida dubliniensis screening. Diagnostic Microbiology and Infectious Diseases, v. 43, p. 85-86, 2002.

ANTUNES, A. G. V.; PASQUALOTTO, A. C.; DIAZ, M. C.; D'AZEVEDO, P. A.; SEVERO, L. C. Candidemia in a Brazilian Tertiary care Hospital: species distribution and antifungal susceptibility patterns. Revista Instituto de Medicina Tropical de São Paulo, v. 46, n. 5, p. 239-241, 2004.

ARAUJO, C. R.; MIRANDA, K. C.; PASSOS, X. S.; SOUZA, L. K. H.; LEMOS, JANINE A.; KHRAIS, C. H. A.; COSTA, C. R.; SILVA M. R. R.; FERNANDES, O. F. L. Identificação das leveduras do gênero Candida por métodos manuais convencionais e pelo método cromógeno Chromagar Candida. Revista de Patologia Tropical, v. 34, n. 1, p. 37-42, 2005.

ARENDRUP, M.C.; GARCIA-EFFRON, G.; LASS-FLORL, C.; LOPEZ, A.G.; RODRIGUEZ-TUDELA, J.L.; CUENCA-ESTRELLA, M.; PERLIN, D.S. Echinocandin susceptibility testing of Candida species: comparison of EUCAST EDef 7.1, CLSI M27A3, Etest, disk diffusion, and agar dilution methods with RPMI and IsoSensitest media. Antimicrobial Agents Chemotherapy, v. 54, n. 1, p. 426-439, 2010.

De acordo com:

ASSOCIACÃO BRASILEIRA DE NORMAS

TÉCNICAS NBR6023: Informação e

Documentação: referências: elaboração. Rio

de Janeiro, 2002. 
ARENDRUP, M.; LUNDGREN, B.; JENSEN, I. M.; HANSEN, B. S.; FRIMODTMOLLER, N. Comparison of Etest and a tablet diffusion test with the NCCLS broth microdilution method for fluconazole and amphotericin B susceptibility testing of Candida isolates. Journal of Antimicrobial Chemotherapy, v. 47, n. 5, p. 521-526, 2001.

AULER, M. E.; Morreira, D.; Rodrigues, F. O.; Abrão, M.; MATSUMOTO, F. E.; Da Silva, E. G.; Da SILVA, B. C. M.; PAULA, C. R. Biofilm formation on intrauterine de vices in patients with recurrent vulvovaginal candidiasis. Medical Mycology, v. 48, n. 1, p. 211216, 2009.

BADIEE, P.; ALBORZI, A.; DAVARPANAH, M. A.; SHAKIBA, E. Distributions and antifungal susceptibility of Candida species from mucosal sites in HIV positive patients. Archives of Iranian Medicine, v. 13, n. 4, p. 282-287, 2010.

BAROUSSE, M. M.; ESPINOSA, T.; DUNLAP, K.; FIDEL, P. L. JR. Vaginal Epithelial Cell Anti-Candida albicans Activity Is Associated with Protection against Symptomatic Vaginal Candidiasis. Infection and Immunity, v. 73, n. 11, 2005.

BEIGI, R. H.; AUSTIN, M. N.; MEYN, L. A.; KROHN, M. A.; HILLIER, S. L. Antimicrobial resistance associated with the treatment of bacterial vaginosis. American Journal of Obstetrics \& Gynecology, v. 191, n. 4, p. 1124-1129, 2004.

BEIGI, R. H.; MEYN, L. A.; MOORE, D. M.; KROHN, M. A.; HILLIER, S. L. Vaginal yeast colonization in nonpregnant women: a longitudinal study. Obstetrics \& Gynecology, v. 104, n. 6, p. 926-930, 2004.

BEIJERINCK, M. W. L'auxanographie, ou la methode de l'hydro diffusion dans la gelatine appliquee aux recherches microbiologique. Arch neerland sci, v. 23, p. 367372, 1889.

BELLOCH, C.; BARRIO, E.; URUBURU, F.; GARCÍA, D. D.; QUEROL, A. Characterization of four species of the genus Kluyveromyces by mitochondrial analisis. Systematic and Applied Microbiology, v. 20, n. 3, p. 397-408, 1997.

BORIOLLO, M. F. G.; HÖFLING, J. F.; MENDES, A.; ROSA, E. A. R. Ferramentas moleculares para caracterização de Candida albicans (Robin) Berkhout (1923) em estudos epidemiológicos. Revista Estudos em Biologia, v. 27, n. 58, p. 21-42, 2005.

BORIOLLO, M. F. G. Análise da diversidade genetica de amostras de Candida albicans isoladas da cavidade bucal de crianças saudaveis por eletroforese de enzima multiloco. 2004. Tese (Doutorado em Biologia Buco-Dental) - Faculdade de Odontologia de Piracicaba, Universidade Estadual de Campinas, Campinas, 2004.

BORIOLLO, M. F. G.; HÖFLING, J. F.; SPOLIDORI, D. M. P.; GRÉGIO, A. M. T.; RYMOVICZ, A. U. M.; CARVALHO, A. P. C.; FERREIRA, L. E. N.; SAMARANAYAKE, L. P.; ROSA, E. A. R. MOLECULAR FINGERPRINTING METHODS FOR STUDIES 
INVOLVING ORAL Candida albicans Métodos de caracterização molecular para estudos envolvendo Candida albicans de origem bucal. Revista de Clínica e Pesquisa Odontológica, v. 5, n. 3, p. 203-224, 2009.

BORST, A.; RAIMER, M. T.; WARNOCK, D. W.; MORRISON, C. J.; ARTHINGTONSKAGGS, B. A. Rapid acquisition of stable azole resistance by Candida glabrata isolates obtained before the clinical introduction of fluconazole. Antimicrobial Agents Chemotherapy, v. 49, n. 2, p. 783-787, 2005.

BRANCHINI, M. L.; PFALLER, M. A.; RHINE-CHALBERG, J.; FREMPONG, T.; ISENBERG, H. D. Genotypic Variation and Slime Production among Blood and Catheter Isolates of Candida parapsilosis. Journal Of Clinical Microbiology, v. 32, n. 2, p. $452-$ 456, 1994.

BRITO, L. R.; GUIMARÃES, T.; NUCCI, M.; ROSAS, R. C.; ALMEIDA, L. P.; DA MATTA, D. A.; COLOMBO, A. L. Clinical and microbiological aspects of candidemia due to Candida parapsilosis in Brazilian tertiary care hospitals. Medical Mycology, v. 44, n. 3,: p. 261-266, 2006.

BROWN, S.M.; CAMPBELL, L. K.; LODGE, J. K. Cryptococcus neoformans, a fungus under stress. Current Opinion in Microbiology, v. 10, n. 4, p. 320-325, 2007.

BULMER, G. S.; MARQUEZ, M. L.; CO-BARCELONA, L.; FROMTLING, R. A. Yeasts and fluconazole susceptibility in the Philippines. Mycopathologia, v. 146, n. 3, p. 117120, 1999.

BUYUKBAYRAK, E. E.; KARS, B.; KARSIDAG, A. Y. K.; KARADENIZ, B. I.; KAYMAZ, O.; GENCER, S.; PIRIMOGLU, Z. M.; UNAL, O.; TURAN, M. C. Diagnosis of vulvovaginitis: comparison of clinical and microbiological diagnosis. Archives of Gynecology and Obstetrics, v. 282, n. 5, p. 515-519, 2010.

CALDERON, L.; WILLIAMS, R.; MARTINEZ, M.; CLEMONS, K.V.; STEVENS, D. A. Genetic susceptibility to vaginal candidiasis. Medical Mycology, v. 41, n. 2, p. 143-147, 2003.

CALVET, H. M.; YEAMAN, M. R.; FILLER, S. G. Reversible fluconazole resistance in Candida albicans: a potential in vitro model. Antimicrobial Agents Chemotherapy, $v$. 41, n. 3, p. 535-539, 1997.

CANDIDO, R. C.; TOLOI, M. R. T.; FRANCESCHINI, S. A.; GARCIA, F. R.; MINTO, E. C. M. In vitro activity ofantimycotic agents determined by E-test method against vaginal Candida species. Mycopathologia, v. 144, n. 1, p. 15-20, 1999.

CANTON, E.; PEMAN, J.; SASTRE, M.; ROMERO, M.; ESPINEL-INGROFF, A. Killing kinetics of caspofungin, micafungin, and amphotericin $B$ against Candida guilliermondii. Antimicrobial Agents and Chemotherapy, v. 50, p. 2829-2832, 2006. 
CARDONA-CASTRO, N.; REVANKAR, S. G.; ORTIZ, P.; CUERVO, C.; KIRKPATRICK, W. R.; MCATEE, R. K.; PATTERSON, T. F. Proteinase detection, DNA typing and antimycotic susceptibility of Candida isolates from Colombian women with vulvovaginal candidiasis. Revista Iberoamericana de Micologia, v. 19, n. 2, p. 8994, 2002.

CARTLEDGE, J. D.; MIDGLEY, J.; GAZZARD, B. G. Non-albicans oral candidosis in HIV-positive patients. Journal Antimicrobial Chemotherapy, v. 43, n. 3, p. 419-22, 1999.

CARRIÇO, J.; PINTO, F.; SIMAS, C.; NUNES, S.; SOUSE, N.; FRAZÃO, N.; DE LENCASTRE, H.; ALMEIDA, J. Assessment of band-based similarity coefficients for automatic type and subtype classification of microbial isolates analysed by Pulsed-Field Gel Electrophoresis. Journal of Clinical Microbiology, v. 43, n. 11, p. 5483-5490, 2005.

CASARI, E.; FERRARIO, A.; MORENGHI, E.; MONTANELLI, A. Gardnerella, Trichomonas vaginalis, Candida, Chlamydia trachomatis, Mycoplasma hominis and Ureaplasma urealyticum in the genital discharge of symptomatic fertile and asymptomatic infertile women. New Microbiologica, v. 33, p. 69-76, 2010.

CASSONE, A.; BERNARDIS, F.; SANTONI, G. Anticandidal immunity and vaginitis: novel opportunities for immune intervention. Infection and Immunity, v. 75, n. 10, p. 4675-86, 2007.

CASSONE, A.; TACCONELLI, E.; DE BERNARDIS, F.; TUMBARELLO, M.; TOROSANTUCCI, A.; CHIANI, P.; CAUDA, R. Antiretroviral therapy with protease inhibitors has an early, immune reconstitution-independent beneficial effect on Candida virulence and oral candidiasis in human immunodeficiency virus-infected subjects. Journal of Infectious Diseases, v. 185, n. 2, p. 188-195, 2002.

CHAFFIN, W. L. Cell Wall Proteins Candida albicans. Microbiology and Molecular Biology Reviews, v. 72, n. 3, p. 495-544, 2008.

CHEN, K. W.; LO, H. J.; LIN, Y. H.; LI, S. Y. Comparison Of Four Molecular Typing Methods To Assess Genetic Relatedness Of Candida albicans Clinical Isolates In Taiwan. Journal Medical Microbiology, v. 54, n. 3, p. 249-258, 2005.

CHEN, Y. C.; EISNER, J. D.; KATTAR, M. M.; RASSOULIAN-BARRETT, S. L.; LAFE, K.; YARFITZ, S. L.; LIMAYE, A. P.; COOKSON, B. T. Identification of medically important yeasts using PCR-based detection of dna sequence polymorphisms in the internal transcribed spacer 2 region of the rrna genes. Journal Clinical Microbiology, v. 38, n. 6, p. 2302-2310, 2000.

CHRYSSANTHOU, E.; CUENCA-ESTRELLA, M. Comparison of the Antifungal Susceptibility Testing Subcommittee of the European Committee on Antibiotic Susceptibility Testing Proposed Standard and the E-test with the NCCLS broth 
microdilution method for voriconazole and caspofungin susceptibility testing of yeast species. Journal Of Clinical Microbiology, v. 40, n. 10, p. 3841-3844, 2002.

CIARDO, D. E.; SCHAR, G.; BOTTGER, E. C.; ALTWEGG, M.; BOSSHARD, P. P. Internal transcribed spacer sequencing versus biochemical profiling for identification of medically important yeasts. Journal of Clinical Microbiology, v. 44, n. 1, p. 77-84, 2006.

COSTA, M.; PASSOS, X. S.; MIRANDA, A. T. B.; ARAÚJO, R. S. C.; PAULA, C. R.; SILVA, M. R. R. Correlation of in vitro itraconazole and fluconazole susceptibility with clinical outcome for patients with vulvovaginal candidiasis. Mycopathologia, v. 157, n. 1, p. 43-47, 2004.

CLAUDINO, A. L.; PEIXOTO, R. F.; MELHEM, M. S.; SZESZS, M. W.; LYON, J. P.; CHAVASCO, J. K.; FRANCO, M. C. Correlation between CLSI, EUCAST and Etest methodologies for amphotericin $B$ and fluconazol antifungal susceptibility testing of Candida spp. clinical isolates. Die Pharmazie, v. 63, n. 4, p. 286-289, 2008.

CLINICAL AND LABORATORY STANDARDS INSTITUTE. Reference method for broth dilution antifungal susceptibility testing of yeasts; Approved standard M27A. Wayne, Pa.: CLSI, 1997. (Document M27-A).

CLINICAL AND LABORATORY STANDARDS INSTITUTE. Reference method for broth dilution antifungal susceptibility testing of yeasts; Approved standard M27A2. Wayne, Pa.: CLSI, 2002. (Document M27-A2).

CLINICAL AND LABORATORY STANDARDS INSTITUTE. Reference method for broth dilution antifungal susceptibility testing of yeasts; Information Suplement. $3^{\text {rd }}$ ed. Wayne, Pa.: CLSI, 2008. (Document M27-S3).

COLOMBO, A. L.; BARCHIESI, F.; MCGOUGH, D. A.; RINALDI, M. G.; Comparison of Etest and National Committee for Clinical Laboratory Standards broth macrodilution method for azole antifungal susceptibility testing. Journal of Clinical Microbiology, $v$. 39, n. 11, p. 535-540, 1995.

COLEMAN, D.; SULLIVAN, D.; HARRINGTON, B.; HAYNES, K.; HENMAN, M.; SHANLEY, D.; BENNETT, D.; MORAN, G.; MCCREARY, C.; O'NEILL, L. Molecular and phenotypic analysis of Candida dubliniensis: a recently identified species linked with oral candidosis in HIV-infected and AIDS patients. Oral Diseases, v. 3, n. 1, 1997.

CONTI, S.; FANTI, F.; BERTOLOTTI, D.; DIECI, E.; ARSENI S, SALATI, A.; POLONELLI, L. Personalized antifungal susceptibility testing. Journal of Antimicrobial Chemotherapy, v. 43, n. 3, p. 333-338, 1999.

COOPER, C. R. JR. Yeasts pathogenic for humans and animals. In: KURTZMAN, C. P.; FELL, J. W.; BOEKHOUT, T. The Yeasts: A Taxonomic Study. 5th ed. Amsterdam: Elsevier. p. 9-19, 2011. 
CORRÊA, P. R.; DAVID, P. R. S.; PERES, N. P.; CUNHA, K. C.; ALMEIDA, M. T. G. Caracterização fenotípica de leveduras isoladas da mucosa vaginal em mulheres adultas. Revista Brasileira de Ginecologia e Obstetrícia, v. 31, n. 4, p. 177-181, 2009.

CUENCA-ESTRELLA, M.; GOMEZ-LOPEZ, A.; ALASTRUEYIZQUIERDO, A.; BERNALMARTINEZ, L.; CUESTA, I.; BUITRAGO, M. J.; RODRIGUEZ-TUDELA, J.L. Comparison of the Vitek 2 antifungal susceptibility system with the Clinical and Laboratory Standards Institute (CLSI) and European Committee on Antimicrobial Susceptibility Testing (EUCAST) Broth Microdilution Reference Methods and with the Sensititre YeastOne and Etest techniques for in vitro detection of antifungal resistance in yeast isolates. Journal Clinical Microbiology, v. 48, n.5, p. 1782-1786, 2010.

CUENCA-ESTRELLA, M.; GOMEZ-LOPEZ, A.; MELLADO, E.; GARCIA-EFFRON,G.; MONZON, A.; RODRIGUEZ-TUDELA, J. L. In vitro activity of ravuconazole against 923 clinical isolates of nondermatophyte filamentous fungi. Antimicrobial Agents Chemotherapy, v. 49, n. 12, p. 5136-5138, 2005.

CUENCA-ESTRELLA, M.; MELLAdO, E.; DÍAZ-GUERRA, T. M.; MONZÓN, A.; RODRÍGUEZ-TUDELA, J. L. Susceptibility of fluconazole-resistant clinical isolates of Candida spp. to echinocandin LY303366, itraconazole and amphotericin B. Journal Antimicrobial Chemotherapy, v. 46, n. 3, p. 475-477.

CUESTA, I.; BIELZA, C.; CUENCA-ESTRELLA, M.; LARRANAGA, P.; RODRIGUEZTUDELA, J.L. Evaluation by data mining techniques of .uconazole breakpoints established by the Clinical and Laboratory Standards Institute (CLSI), and its comparison with those of the European Committee on Antimicrobial Susceptibility Testing. (EUCAST). Antimicrobial Agents and Chemotherapy, v. 54, n. 4, 15411546, 2010.

DABAS, N.; MORSCHHÄUSER, J. A transcription factor regulatory cascade controls secreted aspartic protease expression in Candida albicans. Molecular Microbiology, v. 69, n. 3, p. 586-602, 2008.

DAN, M.; POCH, F.; LEVIN, D. High rate of vaginal infections caused by non-C. albicans species among asymptomatic women. Medical Mycology, v. 40, n. 4, p. 383-386, 2002.

DE BERNARDIS, F.; MONDELLO, F.; MILLÀN, R. S.; PONTÒN, J.; CASSONE, A. Biotyping and virulence properties of skin isolates of Candida parapsilosis. Journal of Infectious Diseases, v. 37, n. 11, p. 3481-3486, 1999.

DE BERNARDIS, F.; SULLIVAN, P. A.; CASSONE, A. Aspartyl proteinases of Candida albicans and their role in pathogenicity. Medical Mycology, v. 39, n. 4, 303-313, 2001.

DE HOOG, G. S.; GUARRO, J.; GENÉ, J.; FIGUERAS, M. J. Atlas of clinical fungi. Tarragona: Universitat Rovira i Virgili, 2000. 126p. 
DIAS, A. L. T.; MATSUMOTO, F. E.; MELHEM, M. S. X.; SILVA, E. G.; AULER, M. E.; SIQUEIRA, A. M.; PAULA, C R. Comparative analysis of Etest and broth microdiluition method (AFST - EUCAST) for trends in antifungal drug susceptibility testing of brazilian Cryptococcus neoformans isolates. Journal Of Medical Microbiology, v. 55, p. 16931699, 2006.

DOI, M.; HOMMA, M.; CHINDAMPORN, A.; TANAKA, K. Estimation of chromosome number and size by pulsed-field gel electrophoresis (PFGE) in medically important Candida species. Journal of General Microbiology, v. 138, n. 10, p. 2243-2251, 1992.

DURAN, M. T.; VELASCO, D.; CANLE, D.; MOURE, R.; VILLANUEVA, R. Antifungal susceptibility of Candida spp. isolates from blood cultures in a five-year period (19972001). Enferm Infecc Microbiol Clin, v.21, n.9, p.488-92, 2003.

ESPINEL-INGROFF, A.; BARCHIESI, F.; CUENCA-ESTRELLA, M.; PFALLER, M. A.; RINALDI, M.; RODRIGUEZ-TUDELA, J. L.; VERWEIJ, P. E. International and multicenter comparison of EUCAST and CLSI M27-A2 broth microdilution methods for testing susceptibilities of Candida spp. to fluconazole, itraconazole, posaconazole, and voriconazole. Journal Clinical Microbiology, v. 43, n. 8, p. 3884-3889, 2005.

ESPINEL-INGROFF, A. Comparison of three commercial assays and a modified disk diffusion assay with two broth microdilution reference assays for testing zygomycetes, Aspergillus spp., Candida spp., and Cryptococcus neoformans with posaconazole and amphotericin B. Journal Of Clinical Microbiology, v. 44, n. 10, p. 3616-3622, 2006.

ESPINEL-INGROFF, A.; CANTON, E.; MARTIN-MAZUELOS, E.; PEMÁN, J. Comparison of anidulafungin MICs determined by the Clinical and Laboratory Standards Institute broth microdilution method (M27-A3 document) and Etest for Candida species isolates. Antimicrobial Agents and Chemotherapy, v. 54, n. 3, p. 1347-1350, 2010.

EUROPEAN COMITEE ON ANTIMICROBIAL SUSCEPTIBILITY. Method for determination of minimal inhibitory concentration (MIC) by broth dilution of fermentative yeasts. Taufkirchen, Germany: European Society of Clinical Microbiology and Infectious Diseases, 2002 (document E. dis. 7.1).

ESTRADA-BARRAZA, D.; MARTÍNEZ, A. D.; FLORES-PADILLA, L.; DE ELIAS, R. M.; LUIS SÁNCHEZ-VARGAS, L. O. Comparación entre métodos convencionales, ChromAgar Candida $\AA^{8}$ y el método de la PCR para la identificación de especies de Candida en aislamientos clínicos. Revista lberoamericana de Micologia, v. 28, n. 1, p. 36-42, 2011.

FALLON, K.; KAUSCH, K.; NOONAN, J.; HUGUENEL, E.; TAMBURINI, P. Role of aspartic proteases in disseminated Candida albicans infection in mice. Infection and Immunity, v. 65, n. 2, p. 551-556, 1997.

FAN, S. R.; LIAO, Q. P.; LIU, X. P.; LIU, Z. H.; ZANG, D. Vaginal allergic response in women with vulvovaginal candidiasis. International Journal of Gynecology \& Obstetrics, v. 101, n.1, p. 27-30, 2008. 
FELK, A.; KRETSCHMAR, M.; ALBRECHT, A.; SCHALLER, M.; BEINHAUER, S.; NICHTERLEIN, T.; SANGLARD, D.; KORTING, H. C.; SCHÄFER, W.; HUBE, B. Candida albicans hyphal formation and the expression of the Efg1-regulated proteases Sap4 to Sap6 are required for the invasion of parenchymal organs. Infection and Immunity, USA, v. 70, p. 3689-700, 2002.

FELL, J. W.; BOEKHOUT, T.; FONSECA, A.; SCORZETTI, G.; STATZELL-TALLMAN, A. Biodiversity and systematics of basidiomycetous yeasts as determined by largesubunit rDNA D1/D2 domain sequence analysis. International Journal of Systematic and Evolutionary Microbiology, v. 50, p. 1351-1371, 2000.

FERRER, J. Vaginal candidosis: epidemiological and etiological factors. International Journal of Gynecology and Obstetrics, v. 71, n. 1, p. 21-27, 2000.

FIDEL, P. L. History And Update On Host Defense Against Vaginal Candidiasis. American Journal Of Reproductive Immunology, v. 57, n. 1, p. 2-12, 2007.

FIDEL, P. L. J.; Sobel, J. D. Immunopathogenesis of Recurrent Vulvovaginal Candidiasis. Clinical Microbiology, v. 9, n. 3, p. 335-348, 1996.

FILLER, S. G. Candida-host cell receptor-ligand interactions. Current Opinion in Microbiology, v. 9, p. 333-339, 2006.

FLECK, R.; DIETZ; A.; HOF, H. In vitro susceptibility of Candida species to five antifungal agents in a German university hospital assessed by the reference broth microdilution method and Etest. The journal of Antimicrobial Chemotherapy, v. 59, $\mathrm{n}$. 4, p. 767-771, 2007.

FLOREZ, A.; ALVAREZ-MARTIN, P.; LOPEZ- DÝAZ, T.; MAYO, B. Morphotypic and molecular identification of filamentous fungi from Spanish blue- veined Cabrales cheese, and typing of Penicillium roqueforti and Geotrichum candidum isolates. International Dairy Journal, v. 17, n. 4, p. 350-357, 2007.

FONSECA, A. FELL, J. W.; KURTZMAN, C. P.; SPENCER-MARTINS, I. Candida tartarivorans sp. nov., an anamorphic ascomycetous yeast with the capacity to degrade $\mathrm{L}(\mathrm{M})$ - and meso-tartaric acid. International Journal of Systematic and Evolutionary Microbiology, v. 50, p. 389-394, 2000.

FOSTER, L. A. Utilization and cell-surface binding of hemin by Histoplasma capsulatum. Canadian Journal of Microbiology, v. 48, n. 5, p. 437-442, 2002.

FRANK, A. T.; RAMSOOK,C. B.; OTOO, H. N.; TAN,C.; SOYBELMAN, G.; RAUCEO,J.M.; GAUR, N. K.; KLOTZ, S. A.; LIPKE, P. N. Structure and function of glycosylated tandem repeats from Candida albicans ALS adhesins. Eukaryotic Cell, v. 9, n. 3, p. 405-414, 2010. 
GARNER, C.; STARR, J. K.; MCDONOUGH, P. L.; ALTIER, C. Molecular Identification of Veterinary Yeast Isolates by Use of Sequence-Based Analysis of the D1/D2 Region of the Large Ribosomal Subunit. Journal Clinical Microbiology, v. 48, n. 6, p. 2140-2146, 2008.

GEIGER, A. M.; FOXMAN, B.; GILLESPIE, B. W. The epidemiology of vulvovaginal candidiasis among University students. American Journal of Public Health, v. 85 n. 81, p.1146-1148, 1995.

GONCALVES, S. S.; AMORIM, C. S.; NUCCI, M.; PADOVAN, A. C.; BRIONES, M. R.; MELO, A. S.; COLOMBO, A. L. Prevalence rates and antifungal susceptibility profiles of C. parapsilosis species complex: results from a nationwide surveillance of candidaemia in Brazil. Clinical Microbiology and Infection, v. 16, n. 7, p. 885-887, 2009.

GONZALEZ, G. M.; PORTILLO, O. J.; USCANGA, G. I.; ANDRADE, S. E.; ROBLEDO, M.; RODRIGUEZ, C.; ELIZONDO, M. Therapeutic efficacy of voriconazole against a fluconazole-resistant Candida albicans isolate in a vaginal model. Journal of Antimicrobial Chemotherapy, v. 64, n. 3, p. 571-573, 2009.

GRIGORIOU, O.; BAKA, S.; MAKRAKIS, E.; HASSIAKOS, D.; KAPPAROS, G.; KOUSKOUNI, E. Prevalence of clinical vaginal candidiasis in a university hospital and possible risk factors. European Journal of Obstetrics \& Gynecology and Reproductive Biology, v. 126, n. 1, p. 121-125, 2006.

GUZEL, A. B.; ILKIT, M.; BURGUT, R.; URUNSAK, I.F.; OZGUNEN, F. T. An evaluation of risk factors in pregnant women with Candida vaginitis and the diagnostic value of simultaneous vaginal and rectal sampling. Mycopathologia, v. 172, n. 1, p. 25-36, 2011.

GYGAX, S. E.; VERMITSKY, J. P.; CHADWICK, S. G.; SELF, M. J.; ZIMMERMAN, J. A.; MORDECHAI, E.; ADELSON, M. E.; TRAMA, J. P. Antifungal resistance of Candida glabrata vaginal isolates and development of a quantitative reverse transcription-PCRbased azole susceptibility assay. Antimicrobial Agents Chemotherapy, v. 52, n. 9, p. 3424-3426, 2008.

HENG, S.; HANNAN, N. J.; ROMBAUTS, L. J. F.; SALAMONSEN, L. A.; NIE, G. PC6 levels in uterine lavage are closely associated with uterine receptivity and significantly lower in a subgroup of women with unexplained infertility. Human Reproduction, v. 26, n. 4, p. 840-846, 2010.

HETTICARACHCHI, N.; ASHBEE, H. R.; WILSON, J. D. Prevalence and management of non-albicans vaginal candidiasis. Sexually Transmitted Infections, v. 82, n. 2, p. 99100, 2010. Published erratum appears in Erratum in: Sexually Transmitted Infections v. 86, n. 3, p. 250, 2010.

HOLANDA, A. A. R. Candidiase vulvovaginal: sintomatologia, fatores de risco e colonizacao anal concomitantes. Revista Brasileira de Ginecologia e Obstetrícia, v. 29, n.1, 2007. 
HOLANDA, A. A. R.; FERNANDES, A. C. S.; BEZERRA, C. M.; FERREIRA, M. A. F.; HOLANDA, M. R. R.; HOLANDA, J. C. P.; MILAN, E. P. Candidíase vulvovaginal: sintomatologia, fatores de risco e colonização anal concomitante. Revista Brasileira de Ginecologia e Obstetrícia, v. 29, n. 1, p. 3-9, 2007.

HOLLAND, J.; YOUNG, M. L.; LEE, O.; CHEN, S. C. A. Vulvovaginal carriage of yasts others than Candida albicans. Sexually Transmitted Infections, v. 79, n. 3, p. $249-$ 250, 2003.

HUBE, B.; SANGLARD, D.; ODDS, F. C.; HESS, D.; MONOD, M.; SCHAFER, W.; BROWN, A. J.; GOW, N. A. Disruption of each of the secreted aspartyl proteinase genes SAP1, SAP2, and SAP3 of Candida albicans attenuates virulence. Infection_and Immunity, v. 65, n. 9, p. 3529-3538, 1997.

IBRAHIM, A. S.; MIRBOD, F.; FILLER, S. G.; BANNO, Y.; COLE, G. T.; KITAJIMA, Y.; EDWARDS JR., J. E.; NOZAWA, Y.; GHANNOUM, M. A. Evidence implicating phospholipase as a virulence factor of Candida albicans. Infection and Immunity, $v$. 63, n. 5,p. 1993-1998, 1995.

IIDA, S.; IMAI, T.; OGURI, T.; OKUZUMI, K.; YAMANKA, A.; MORETTI-BRANCHINI, M.; NISHIMURA, K.; MIKAMI, Y. Genetic diversity of the internal transcribed spacers (ITS) and 5.8 S rRNA genes among clinical isolates of Candida parapsilosis in Brazil and Japan. Japanese Journal of Medical Mycology, v. 46, p. 133-137, 2005.

ISHIGURO, A.; HOMMA, M.; TORII, S.; TANAKA, K. Identification of Candida albicans antigens reactive with immunoglobulin $E$ antibody of human sera. Infection and Immunity, v. 60, n. 4, p. 1550-1557, 1992.

IWEN, P. C.; HINRICHS, S. H.; RUPP, M. E. Utilization of the internal transcribed spacer regions as molecular targets to detect and identify human fungal pathogens. Medical Mycology, v. 40, n. 1, p. 87-109, 2002.

KANTARCIOGLU, A. S.; ŸUCEL, A. Phospholipase and protease activities in clinical Candida isolates with reference to the sources of strains. Mycoses, v. 45, p.160-165, 2002.

KATIYAR, S.; PFALLER, M.; EDLIND, T. Candida albicans and Candida glabrata clinical isolates exhibiting reduced echinocandin susceptibility. Antimicrobial Agents Chemotherapy, v.. 50, n. 8, p. 2892-2894, 2006

KAUFMANN, C. S.; MERZ, W. G. Electrophoretic karyotypes of Torulopsis glabrata. Journal of Clinical Microbiology, v. 27, n. 21, p. 2165-2168, 1989.

KHATTAK, M. N.; BURNIE, J. P.; MATTHEWS, R. C.; OPPENHEIM, B. Clamped homogeneous electric field gel electrophoresis typing of Toruiupsis gldrata isolates 
causing nosocomial infections. Journal of Clinical Microbiology, v. 30, n. 8, p. 22112215, 1992.

KIRAZ, N.; DAG, I.; OZ, Y.; YAMAC, M.; KIREMITCI, A.; KASIFOGLU, N. Correlation between broth microdilution and disk diffusion methods for antifungal susceptibility testing of caspofungin, voriconazole, amphotericin B, itraconazole and fluconazole against Candida glabrata. Journal of Microbiological Methods, v. 82, n. 2, p. 136-140, 2010.

KOTHAVADE, R. J.; KURA, M. M.; VALAND, A. G.; PANTHAKI, M. H. Candida tropicalis: its prevalence, pathogenicity and increasing resistance to fluconazole. Journal of Medical Microbiology, v. 59, n. 8, p. 873-880, 2010.

KRYSAN, D. J.; TING, E.L.; ABEIJON, C.; KROOS, L.; FULLER, R. S.. Yapsins Are A Family Of Aspartyl Protease Required For Cell Wall Integrity In Saccharomyces Cerevisiae. Eukaryotic Cell, v. 4, n. 8, p. 1364-1374, 2005.

KUO, D.; TAN, K.; ZINMAN, G.; RAVASI, T.; BAR-JOSEPH, Z.; IDEKER, T. Evolutionary divergence in the fungal response to fluconazole revealed by soft clustering. Genome Biology, v. 11, R77, 2010.

KURTZMAN, C. P.; ALBERTYN, J.; BASEHOAR-POWERS, E. Multigene phylogenetic analysis of the Lipomycetaceae and the proposed transfer of Zygozyma species to Lipomyces and Babjevia anomala to Dipodascopsis. FEMS Yeast Research, v. 7, n. 6, p. 1027-1034, 2007.

KURTZMAN, C.P.; FELL, J.W. The Yeast a Taxonomic Study. 4th. Burllington, MA, EUA. Elsevier Science, 1998. 1076p.

KURTZMAN, C. P.; FELL, J. W.; BOEKHOUT, T. The yeasts, a taxonomic study. 5th. Burllington, MA, EUA. Elsevier Science, 2011. 2354 p.

KURTZMAN, C. P.; ROBNETT, C. J. Identification of clinically important ascomycetous yeasts based on nucleotide divergence in the 5 ' end of the large-subunit (26S) ribosomal DNA gene. Journal of Clinical Microbiology, v. 35, n. 5, p. 12161223, 1997.

LANDERS, D. V.; WIESENFELD, H. C.; HEINE, R. P.; KROHN, M. A.; HILLIER, S. L. Predictive value of the clinical diagnosis of lower genital tract infection in women. American Journal of Obstetrics Gynecology, v. 190, n.4, p. 1004-1010, 2004

LIAN, C. H.; LIU, W. D. Differential expression of Candida albicans secreted aspartyl proteinase in human vulvovaginal candidiasis. Mycoses, v. 50, n. 5, p. 383-390, 2007.

LEVI, A. W.; HARIGOPAL, M.; HUI, P.; SCHOFIELD, K.; CHHIENG, D. C. Comparison of Affirm VPIII and Papanicolaou tests in the detection of infectious vaginitis. American Journal Clinical Pathology, v. 135, n. 3, p. 442-447. 
LIGUORI, G.; GALLÉ, F.; LUCARIELLO, A.; DI ONOFRIO, V.; ALBANO, L.; MAZZARELLA, G.; D'AMORA, M.; ROSSANO, F. Comparison between multiplex PCR and phenotypic systems for Candida spp. identification. New Microbiologica, v. 33, n. 1, p. 63-67, 2010.

LIMA, K. M.; Rëgo, R. S. M. F. M.; N. S. S.Espécies fúngicas responsáveis por onicomicose em Recife, Pernambuco. Revista Brasileira de Análises Clínicas, v. 40, n. 2, p.107-110, 2008.

LIMA-NETO, R. G.; BELTRÃO, E. I.; OLIVEIRA, P. C.; NEVES, R. P. Adherence of Candida albicans and Candida parapsilosis to epithelial cells correlates with fungal cell surface carbohydrates. Mycoses, v. 54, n. 1, p. 23-29, 2011.

LINARES, M. J.; CHARRIEL, G.; SOLIS F.; CASAL, M. Comparison of two microdiluition methods for testing susceptibility of Candida spp. to voriconazole. Journal Of Clinial Microbiology, v. 42, n. 2, p. 899-902, 2004.

LIU, O. W.; CHUN, C. D.; CHOW, E. D.; CHEN, C.; MADHANI, H. D.; NOBLE, S. M. Systematic genetic analysis of virulence in the human fungal pathogen Cryptococcus neoformans. Cell, v. 135, n. 1, p. 174-188, 2008.

LOCKHART, S. R.; MESSER, S. A.; PFALLER, M. A.; DIEKEMA, D. J. Geographic Distribution and Antifungal Susceptibility of the Newly Described Species Candida orthopsilosis and Candida metapsilosis in Comparison to the Closely Related Species Candida parapsilosis. Journal of Clinical Microbiology, v. 46, n. 8, p. 2659-2664, 2008.

LORETO, E. S.; SCHEID, L. A..; NOGUEIRA, C. W.; ZENI, G.; SANTURIO, J. M.; ALVES, S. H. Candida dubliniensis: Epidemiology and Phenotypic Methods for Identification. Mycopathologia, v. 169, n. 6, p. 431-443, 2010.

MADHAVAN, P.; JAMAL F.; CHONG, P. P. Laboratory isolation and identification of Candida species. Journal of Applied Sciences, v. 11, n. 16, p. 2870-2877, 2011.

MAFFEI, C. M.; PAULA, C. R.; MAZZOCATO, T. S.; FRANCESCHINI, S. Phenotype and genotype of Candida albicans strains isolated from pregnant women with recurrent vaginitis. Mycopathologia, v. 137, n. 2, p. 87-94, 1997.

MANNARELLI, B. M.; KURTZMAN, C. P. Rapid identification of Candida albicans and other human pathogenic yeasts by using short oligonucleotides in a PCR. Journal of Clinical Microbiology, v. 36, n. 8, p. 1634-1641, 1998.

MARDH, P. A.; RODRIGUES, A. G.; GENC, M.; NOVIKOVA, N.; MARTINEZ-DEOLIVEIRA, J.; GUASCHINO, S. Facts and myths on recurrent vulvovaginal candidosis-a 
review on epidemiology, clinical manifestations, diagnosis, pathogenesis and therapy. International Journal of STD \& AIDS, v. 13, n. 8, p. 522-539, 2002.

MARIANO, P. L. S.; MILAN, E. P.; MATTA, D. A.; COLOMBO, A. L. Candida dubliniensis identification in Brazilian yeast stock collection. Memórias Instituto Oswaldo Cruz, v. 98, n. 4, p. 533-538, 2003.

MARINA, N. M.; FLYNN, P. M.; RIVERA, G. K.; HUGHES, W. T. Candida tropicalis and Candida albicans fungemia in children with leukemia. Cancer, v. 68, n. 3, p. 594-599, 1991.

MARRAZZO, J. M.; KOUTSKY, L. A.; ESCHENBACH, D. A.; AGNEW, K.; STINE, K.; HILLIER, S. L. Characterization of vaginal flora and bacterial vaginosis in women who have sex with women. Journal Infectious Diseases, v. 185, n. 9, p. 1307-1313, 2002.

MARTINEZ, R. C.; FRANCESCHINI, S. A.; PATTA, M. C.; QUINTANA, S. M.; CANDIDO, R. C.; FERREIRA, J. C.; DE MARTINIS, E. C.; REID, G. Improved Treatment of Vulvovaginal Candidiasis with Fluconazole plus Probiotic Lactobacillus rhamnosus GR-1 and Lactobacillus reuteri RC-14. Letters in Applied Microbiology, v. 48, n. 3, p. 269-274, 2009.

MARTIN-MAZUELOS, E.; GUTIERRES, M.J.; ALLER, A.I.; BERNAL, S.; MARTINEZ, N.A.; MONTEIRO, O.; QUINDOS, G. A comparative evaluation of ETEST and broth microdiluition methods for fluconazole and itraconazole susceptibility testing of Candida spp. The Journal of Antimicrobial Chemotherapy, v. 43, n. 4, p. 477-481, 1999.

MASATA, J.; POISLOVÁ, M.; JEDLICKOVÁ, A.; MASATOVÁ, D.; MARTAN, A. Modified classification of microscopic evaluation of vulvovaginal infections. Ceska Gynekologie, v. 75, n. 3,p. 199-208, 2010.

MASHBURN, J. Etiology, diagnosis and management of vaginitis. Journal of Midwifery and Women's Health, v. 51, n. 6, p. 423-30, 2006.

MARTIN-MAZUELOS, E.; GUTIERREZ, M. J.; ALLER, A. I.; BERNAL, S.; MARTÍNEZ, M. A.; MONTERO, O.; QUINDÓS, G. A comparative evaluation of Etest and broth microdilution methods for fluconazole and itraconazole susceptibility testing of Candida spp. Journal of Antimicrobial Chemotherapy, v. 43, n. 4, p. 477-481, 1999.

MCCLELLAND, E. E.; BERNHARDT, P.; CASADEVALL, A. Estimating the relative contributions of virulence factors for pathogenic microbes. Infection and Immunity, $v$. 74, n. 3, p. 1500-1504, 2006. 
MCCLELLAND, R. S.; RICHARDSON, B. A.; HASSAN, W. M.; GRAHAM, S. M.; KIARIE, J.; BAETEN, J. M. MANDALIYA, K.; JAOKO, W.; NDINYA-ACHOLA, J. O.; HOLMES, K. K. Prospective study of vaginal bacterial flora and other risk factors for vulvovaginal candidiasis. Journal Infectious Diseases, v. 199, n. 12, p. 1883-1890, 2009.

MENDLING, W.; KRAUSS, C.; FLADUNG B. A clinical multicenter study comparing efficacy and tolerability of topical combination therapy with clotrimazole (Canesten, two formats) with oral single dose fluconazole (Diflucan) in vulvovaginal mycoses. Mycoses, v. 47, n. $3-4$, p. $136-42,2004$.

MENDLING, W.; SEEBACHER, C.; WORKING GROUP FOR INFECTIONS AND INFECTIMMUNOLOGY OF THE GERMAN SOCIETY FOR GYNECOLOGY AND OBSTETRICS; GERMAN SPEAKING MYCOLOGICAL SOCIETY; GERMAN DERMATOLOGICAL SOCIETY. Guideline vulvovaginal candidosis: guideline of the German Dermatological Society, the German Speaking Mycological Society and the Working Group for Infections and Infectimmunology of the German Society for Gynecology and Obstetrics. Mycoses, v. 46, n. 9-10, p. 365-369, 2003.

MENDLING, W. Vulvo-vaginal Candidosis: Theory and Practice. Berlin: SpringerVerlag, 1988.

MERZ, W. G.; CONNELLY, C.; HIETER, P. Variation of electrophoretic karyotypes among clinical isolates of Candida albicans. Journal of Clinical Microbiology, v. 26, n. 5, p. 842-845, 1988.

MICELI, M.H., DÍAZ, J.A. \& LEE, S.A. Emerging opportunistic yeast infections. Lancet Infectious Disease, v. 11, n. 2, p. 142-151, 2011.

MOHANTY, S.; XESS, I.; HASAN, F.; KAPIL,A.; MITTAL, S.; TOLOSA, J. E. Prevalence \& susceptibility to fluconazole of Candida species causing vulvovaginitis. Indian Journal of Medical Research, v.126, p.216-9, 2007.

MOREIRA, D.; PAULA C. R. Vulvovaginal candidiasis. International Journal of Gynecology and Obstetrics, v. 92, n. 3, p. 266-267, 2006.

MOREIRA, D. Perfil fenotípico, diferenciação molecular, produção de enzimas e sensibilidade aos antifúngicos de amostras de leveduras isoladas em três grupos amostrais: mulheres assintomáticas, com candidíase vulvovaginal primária e recorrente. Instituto de Ciências Biomédicas, Universidade de São Paulo, São Paulo, 2012.

MIYAZAKI, T.; IZUMIKAWA, K.; NAGAYOSHI, Y.; SAIJO, T.; YAMAUCHI, S.; MORINAGA, Y.; SEKI, M.; KAKEYA, M.; YAMAMOTO, Y.; YANAGIHARA, K.; MIYAZAKI, Y.; KOHNO, S. Functional characterization of the regulators of calcineurin in Candida glabrata. FEMS Yeast Research, v. 11, n. 8, p. 621-630, 2011. 
MORSCHHÄUSER, J.; VIRKOLA, R.; KORHINEN, T. K.; HACKER, J. Degradation of human subendothelial extracellular matrix by proteinase-secreting Candida

albicans. FEMS Microbiology, v. 153, n. 2, p. 349-55, 1997.

Nacional Center for Biotechnology Information. GenBank. Disponível em $<$ http://blast.ncbi.nlm. nih.gov/Blast.cgi/>.

NAGAPPAN, V.; BOIKOV, D.; VAZQUEZ, J. A. Assessment of the In Vitro Kinetic Activity of Caspofungin against Candida glabrata. Antimicrobial Agents and Chemoterapy, v. 54, n. 1, 2010.

NAGLIK, J.; ALBRECHT, A.; BADER, O.; HUBE, B. Candida albicans proteinases and host/pathogen interactions. Cellular Microbiology, v. 6, n. 10, p. 915-926, 2004.

NAGLIK, J. R.; CHALLACOMBE, S. J.; HUBE, B. Candida albicans secreted aspartyl proteinases in virulence and pathogenesis. Microbiology and Molecular Biology Reviews, v. 67, n. 3, p. 400-428, 2003a.

NAGLIK, J.R.; FIDEL Jr, PL.; ODDS, F.C. Animal models of mucosal Candida infection. FEMS Yeast Research, v. 283, p.129-139, 2008.

NAGLIK, J. R.; FOSTIRA, F.; RUPRAI, J.; STAAB, J. F.; CHALLACOMBE, S. J.; SUNDSTROM, P. Candida albicans HWP1 gene expression and host antibody responses in colonization and disease. Journal Of Medical Microbiology, v. 55, p. 1323-1327, 2006.

NAGLIK, J. R.; RODGERS, C. A.; SHIRLAW, P. J.; DOBBIE, J. L.; FERNANDESNAGLIK, L. L.; GREENSPAN, D.; AGABIAN, N.; CHALLACOMBE, S. J. Differential expression of Candida albicans secreted aspartyl proteinase and phospholipase $B$ genes in humans correlates with active oral and vaginal infections. Journal of Infectious Diseases, v. 188, n. 3, p. 469-479, 2003b.

NOBLE, S. M.; JOHNSON, A. D. Strains and strategies for large-scale gene deletion studies of the diploid human fungal pathogen Candida albicans. Eukaryotic Cell, v. 4, n. 2, p.298-309, 2005.

NWOKOLO, N. C.; BOAG, F. C. Chronic vaginal candidiasis. Management in the postmenopausal patient. Drugs \& Aging, v. 16, n. 5, 2000.

NYIRJESY, P. Vulvovaginal candidiasis and bacterial vaginosis. Infectious Disease Clinics of North America, v. 22, p. 637-652, 2008.

NYIRJESY, P.; ALEXANDER, A. B.; WEITZ, M. V. Vaginal candida parapsilosis: pathogen or bystander? Infectious Diseases in Obstetrics and Gynecology, v. 13, n. 1, p. 37-41, 2005. 
ODDS, F.C.; BROWN, A.J.; GOW, N.A. Antifungal agents: Mechanism of action. TRENDS in microbiology, v. 11, n. 6, p. 272-279. 2003.

ODDS, F. C. Molecular phylogenetics and epidemiology of Candida albicans. Future Microbiology, v. 5, n. 1, p. 67-79, 2010.

OMBRELLA, A. M.; RACCA, L.; RAMOS, L. Actividades proteinasa y fosfolipasa de aislamientos de Candida albicans provenientes de secreciones vaginales con distintos valores de pH. Revista Iberoamericana de Micología, v. 25, n. 1, p. 12-16, 2008.

OSTROSKY-ZEICHNER, L.; REX, J. H.; PAPPAS, P. G.; HAMILL, R. J.; LARSEN, R. A.; HOROWITZ, H. W.; POWDERLY, W. G.; HYSLOP, N.; KAUFFMAN, C. A.; CLEARY, J.; MANGINO, J. E.; LEE, J. Antifungal susceptibility survey of 2,000 bloodstream Candida isolates in the United States. Antimicrobial Agents and Chemoterapy, v. 47, n. 10, p. 3149-3154, 2003.

OZCAN, S. K.; BUDAK, F.; WILLKE, A.; FILIZ, S.; COSTUR, P.; DALCIK, H. Efficacies of caspofungin and a combination of caspofungin and meropenem in the treatment of murine disseminated candidiasis. APMIS, v. 114, n. 12, p. 829-836, 2006.

PAULA, C.R.; PURCHIO, A.; GAMBALE, W. Yeasts from beaches in the Southem Area of São Paulo state. "Baixada Santista", Brasil. Revista de Microbiologia, São Paulo, v. 14, n. 2, p. 136-143, 1983.

PEMÁN, J.; CANTÓN, E.; CALABUIG, E.; BOSCH, M.; VALENTÍN, A.; VIUDES, A.; GOBERNADO, M. Actividad in vitro del voriconazol frente a levaduras y algas con los nuevos puntos de corte del patrón de resistência. Revista Española de Quimioterapia,v. 19, N. 1, p. 21-33, 2006.

PEMÁN, J.; CANTÓN, E.; LINARES-SICILIA, M. J.; ROSELLÓ, E. M.; BORRELL, N.; RUIZ-PÉREZ-DE-PIPAON, M. T.; GUINEA, J.; GARCÍA, J.; PORRAS, A.; GARCÍATAPIA, A. M.; PÉREZ-DEL-MOLINO, L.; SUÁREZ, A.; ALCOBA, J.; GARCÍA-GARCÍA, I. Epidemiology and antifungal susceptibility of bloodstream fungal isolates in pediatric patients: a Spanish multicenter prospective survey. Journal Clinical Microbiology, v. 49, n.12, p. 4158-4163, 2011.

PENHA, S. S.; BIRMAN, E. G.; SILVEIRA, F. R. X.; PAULA, C. R. Frequency and enzymatic activity (proteinase and phospholipase) of Candida albicans from edentulous patients, with and without denture stomatitis. Pesquisa Odontológica Brasileira, v. 14, n. 2, p. 119-122, 2000.

PFALLER, M. A.; ANDES, D.; DIEKEMA, D. J.; ESPINEL-INGROFF, A.; SHEEHAN, D.; THE GLOBAL ANTIFUNGAL SURVEILLANCE GROUP. Wild-type MIC distributions, epidemiological cutoff values and species-specific clinical breakpoints for fluconazole and Candida: Time for harmonization of CLSI and EUCAST broth microdilution methods. Journal Of Clinical Microbiology, v. 48, p. 1366-1377, 2010. 
PFALLER, M. A.; DIEKEMA, D. J.; ANDES, D.; ARENDRUP, M. C.; BROWN, S. D.; LOCKHART, S. R.; MOTYL, M.; PERLIN, D. S.; THE CLSI SUBCOMMITTEE FOR ANTIFUNGAL TESTING. Clinical breakpoints for the echinocandins and Candida revisited: integration of molecular, clinical, and microbiological data to arrive at speciesspecific interpretive criteria, Drug Resistance Updates, v. 14, n. 3, p. 164-176, 2011;

PFALLER, M. A.; DIEKEMA, D.J.; MESSER, S. A.; BOYKEN, L.; HOLLIS, R. J. Activities of fluconazole and voriconazole against 1,586 recent clinical isolates of Candida species determined by broth microdilution, disk diffusion, and etest methods: report from the ARTEMIS global antifungal susceptibility program, 2001. Journal Of Clinical Microbiology, v. 41, n. 4, p. 1440-1446, 2003.

PFALLER, M.A.; DIEKEMA, D.J. Epidemiology of Invasive Candidiasis: a Persistent Public Health Problem. Clinical Microbiology Reviews, v. 20, n. 1, p. 133-163, 2007.

PFALLER, M. A.; DIEKEMA, D. J.; REX, J. H.; ESPINEL-INGROFF, A.; JOHNSON, E. M.; ANDES, D.; CHATURVEDI, V.; GHANNOUM, M. A.; ODDS, F. C.; RINALDI, M. G.; SHEEHAN, D. J.; TROKE P.; WALSH, T. J.; WARNOCK, D. W. Correlation of MIC with outcome for Candida species tested against voriconazole: analysis and proposal for interpretive breakpoints. Journal Of Clinical Microbiology, v. 44, n. 3, p. 819-826, 2006.

PFALLER, M. A. Nosocomial candidiasis: emerging species, reservoirs, and modes of transmission. Clinical Infectious Diseases, v. 22, n. 2, p. 89-94, 1996.

PFALLER, M. A.; Sheehan, D. J.; Rex, J. H. Determination of fungicidal activities against yeasts and molds: lessons learned from bactericidal testing and the need for standardization. Clinical Microbiology Reviews, v. 17, n. 2, p. 268-280, 2004.

PINCUS, D. H.; ORENGA, S.; CHATELLIER, S. Yeast identification-past, present, and future methods. Medical Mycology, v. 45, n. 2, p. 97-121, 2007.

PIROTTA, M. V.; GARLAND, S. M. Genital Candida species detected in samples from women in Melbourne, Australia before and after treatment with antibiotics. Journal Of Clinical Microbiology, v. 44, v. 9, p. 3213-3217, 2006.

PRICE, M.F.; WILKINSON, I.D.; GENTRY, L.O. Plate methods for detection of phospholipase activity in Candida albicans. Sabouraudia, v. 20, n. 1, p. 7-14, 1982.

QI, Q. G.; HU, T.; ZHOU, X. D. Frequency, species and molecular characterization of oral Candida in hosts of different age in China. Journal of Oral Pathology \& Medicine, v. 34, n. 6, p. 352-356, 2005.

REEF, S. E. Treatment options for vulvogavinal candidiasis: background paper for development of 1993 STD treatment recommendations. Clinical Infectious Diseases, v. 20, p. $580-590,1995$. 
REX, J. H.; PFALLER, M. A.; GALGIANI, J. N.; BORTLETT, M. S.; ESPINEL-INGROFF, A; GHANNOUM, M. A.; LANCASTER, M.; ODDS, F. C.; RINALDI, M. G.; WALSH, T. J.; BARRY, A. L. Development of interpretive breakpoints for antifungal susceptibility testing: conceptual framework and analysis of in vitro correlation data for fluconazole, itraconazole and Candida infections. Clinical Infectious Diseases, v. 24, n. 2, p. 235247, 1997.

RIBEIRO, M.A.; DIETZE, R.; PAULA, C. R.; DA MATA, D. A., COLOMBO, A. L. Susceptibility profile of vaginal yeastisolates from Brazil. Mycophatologia, v.151, n. 1, p. 5-10, 2000.

RIBEIRO, M. A.; PAULA, C. R.; PERFECT, J. R.; COX, G. M. Phenotypic and genotypic evaluation of fluconazole resistance in vaginal Candida strains isolated from HIVinfected women from Brazil. Medical Mycology, v. 43, n. 7, p. 647-650, 2005.

RIBEIRO, E.L.; GUIMARÃES, R. I.; INÁCIO, M. C. C.; FERREIRA, W. M.; CARDOSO, C. G.; DIAS, S. M. S.; NAVES, P. L. F. Aspectos de leveduras do gênero Cândida vinculadas às infecções nosocomiais. Newslab, v. 64, 2004.

RICHTER, S. S.; GALASK, R. P.; MESSER, S. A.; HOLLIS, R. J.; DIEKEMA, D. J.; PFALLER, M. A. Antifungal susceptibilities of Candida species causing vulvovaginitis and epidemiology of recurrent cases. Journal Clinical Microbiology, v. 43, n. 5, p. 2155-2162, 2005.

RIPEAU, J. S.; FIORILLO, M.; AUMONT, F.; BELHUMEUR, P.; REPENTIGNY, L. Evidence for differential expression of Candida albicans virulence genes during oral infection in intact and human immunodeficiency virus type 1-transgenic mice. The Journal of Infectious Diseases, v. 185, n. 8, p. 1094-1102, 2002.

RODRIGUEZ-TUDELA, J. L.; GOMEZ-LOPEZ, A.; ALASTRUEY-IZQUIERDO, A.; MELLADO, E.; BERNAL-MARTINEZ, L.; CUENCA-ESTRELLA, M. Genotype distribution of clinical isolates of Trichosporon asahii based on sequencing of intergenic spacer 1. Diagnostic Microbiology and Infectious Disease, v. 58, n. 4, p. 435-440, 2007.

RODRIGUEZ-TUDELA, J. L.; GOMEZ-LOPEZ, A.; ARENDRUP, M. C.; GARCIAEFFRON, G.; PERLIN, D. S.; LASS-FLÖRL, C.; CUENCA-ESTRELLA, M. Comparison of caspofungin MICs by means of EUCAST method EDef 7.1 using two different concentrations of glucose. Antimicrobial Agents Chemotherapy, v. 54, n. 7, p. 30563057, 2010.

ROETZER, A.; GABALDÓN, T.; SCHÜLLER, C. From Saccharomyces cerevisiae to Candida glabrata in a few easy steps: important adaptations for an opportunistic pathogen. FEMS Microbiology Letters, v. 314, n. 1, p. 1-9, 2011. 
ROSENBACH, A.; DIGNARD, D.; PIERCE, J.V.; WHITEWAY, M.; KUMAMOTO, C. A. Adaptations of Candida albicans for growth in the mammalian intestinal tract. Eukaryotic Cell, v. 9, n. 7, p.1075-1086, 2010.

RUCHEL, R.; TEGELER, R.; TROST, T. M. A comparison of secretory proteinases from different strains of Candida albicans. Sabouraudia, v. 20, n. 3, p. 233-244, 1982.

SANDHU, G. S.; KLINE, B. C.; STOCKMAN, L.; ROBERTS, G. D. Molecular probes for diagnosis of fungal infections. Journal Of Clinical Microbiology, v. 33, n. 11, p. 29132919, 1995.

SANGLARD, D. Clinical relevance of mechanisms of antifungal drìg resistance in yeast. Enfermedades Infecciosas y Microbiologia Clínica, v. 20, n. 9, p. 462-470, 2002.

SANGLARD, D.; ODDS, F. C. Resistance of Candida species to antifungal agents: molecular mechanisms and clinical consequences. The Lancet Infectious Diseases, $v$. 2, n. 2, p. 73-85, 2002.

SÁNCHEZ, R. R.; PAZ, R. F.; ALBA, M. A. Identificación de especies de Candida causantes de vaginitis en la población mexicana. Enfermedades Infecciosas y Microbiologia Clinica, v. 24, n. 10, p. 634-636, 2006.

SCHULZE, J.; SONNENBORN, U. Yeasts in the gut: from commensals to infectious agents. Deutsches Ärzteblatt International, v. 106, n. 51-52, p. 837-841, 2009.

SCORZETTI, G.; FELL, J. W.; FONSECA, A.; STATZELL-TALLMAN, A. Systematics of basidiomycetous yeasts: a comparison of large sub-unit D1D2 and internal transcribed spacer rDNA regions. Fems Yeast Research, v. 2, n. 4, p. 495-517, 2002.

SEIDMAN, L. S.; SKOKOS, C. K. An evaluation of butoconazole nitrate $2 \%$ site release vaginal cream (Gynazole-1) compared to fluconazole $150 \mathrm{mg}$ tablets (Diflucan) in the time to relief of symptoms in patients with vulvovaginal candidiasis. Infectious Diseases in Obstetrics and Gynecology, v. 13, n. 4, p. 197-206, 2005.

SHAH, D.; ZHANG, Z.; KHODURSKY, A., KALDALU, N.; KURG, K.; LEWIS, K. Persisters: a distinct physiological state of E. coli. BMC Microbiology, v. 6, n. 53, 2006.

SHAHID, Z.; SOBEL, J. D. Reduced fluconazole susceptibility of Candida albicans isolates in women with recurrent vulvovaginal candidiasis: effects of long-term fluconazole therapy. Diagnostic Microbiology and Infectious Diseases, v. 64, n. 3, p. 354-6, 2008.

SHIN J. H.; PARK, M. R.; SONG, J. W.; SHIN, D. H.; JUNG, S. I.; CHO, D.; KEE, S. J.; SHIN, M. G.; SUH, S. P.; RYANG, D. W. Microevolution of Candida albicans strains during catheter-related candidemia. Journal Of Clinical Microbiology, v. 42, n. 9, p. 4025-4031, 2004. 
SHIN, J. H.; SHIN, D. H.; SONG J. W.; KEE, S. J.; SUH, S. P.; RYANG, D. W. Electrophoretic karyotype analysis of sequential Candida parapsilosis isolates from patients with persistent or recurrent fungemia. Journal Of Clinical Microbiology, v. 39, n. 4, p. 1258-1263, 2001.

SIKORA, M.; DABKOWSKA, M.; SWOBODA-KOPEC, E.; JARZYNKA, S.; NETSVYETAYEVA, I.; JAWORSKA-ZAREMBA,M.; PERTKIEWICZ, M.; MLYNARCZYK, G. Differences in proteolytic activity and gene profiles of fungal strains isolated from the total parenteral nutrition patients. Folia Microbiologica, v. 56, n.2, p. 143-148, 2011.

SILVA, M. R. R.; COSTA, M. R.; MIRANDA, A. T. B.; FERNANDES, O. F. L.; COSTA, C. R.; PAULA, C. R. Evaluation Of Etest And Macrodilution Broth Method For Antifungal Susceptibility Testing Of Candida Sp Strains Isolated From Oral Cavities Of Aids Patients. Revista Instituto Medicina Tropical de São Paulo, v.44, n.3, p. 121-125, 2002.

SHÜNJI, T.; NAOKO, F.; TAKASHI, S.; TOYOICHIRO, K.; YOSHITSUGU, L.; SATOSHI, I. National surveiliance of species distribution in bood isolates of Candida spp in Japan and their susceptibility to six antifungal agents incluing voriconazole and micafungin. Journal of Antimicrobial Chemotherapy, v. 53, n. 2, p. 283-289, 2004.

SOBEL, J. D. Bacterial etiologic agents in the pathogenesis of urinary tract infections. Medical Clinics of North America, v. 75, n. 2, p. 253, 1991.

SOBEL, J. D. Vulvovaginal Candidosis. Lancet, London, v. 369, n. 9577, p. 19611971, 2007.

SOBEL, J. D. Vulvovaginitis due to Candida glabrata. An emerging problem. Mycoses, v. 41, n. 2, p. 18-21, 1998.

SOBEL, J. D. Vaginitis due to Saccharomyces cereviseae: Epidemiology, clinical aspects, and therapy. Clinical Infectious Diseases, v. 16, n. 1, p. 93-99, 1993.

SOBEL, J. D.; WIESENFELD, H. C.; MARTENS, M.; DANNA, P.; HOOTON, T. M.; ROMPALO, A.; SPERLING, M.; LIVENGOOD, C.; HOROWITZ, B.; VON THRON, J.; EDWARDS, L.; PANZER, H.; .D., CHU, T. C. Maintenance Fluconazole Therapy for Recurrent Vulvovaginal Candidiasis. The New England Journal of Medicine, v. 351, p. 876-883, 2004.

SOBEL, J. D.; ZERVOS, M.; REED, B. D.; HOOTON, T. SOPER, D.; NYIRJESY, P.; HEINE, M. W.; WILLEMS, J.; PANZER, H. Fluconazole Susceptibility of Vaginal Isolates Obtained from Women with Complicated Candida Vaginitis: Clinical Implications. Antimicrobial Agents And Chemotherapy, v. 47, n. 1, p. 34-38, 2003.

SOJAKOVA, M.; LIPTAJOVA, D.; BOROVSKY, M.; SUBIK, J. Fluconazole and itraconazole susceptibility of vaginal yeast isolates from Slovakia. Mycophatologia, $v$. 157, n. 2, p. 163-169, 2004. 
SOLL, D. R.; GALASK, R.; SCHMID, J.; HANNA, C.; MAC, K.; MORROW, B. Genetic dissimilarity of commensal strains of Candida spp. carried in different anatomical locations of the same healthy women. Journal of Clinical Microbiology, v. 29, n.8, p. 1702-1710, 1991.

SOUTHERN, P.; HORBUL, J.; MAHER, D.; DAVIS, A. C. albicans Colonization Of Human Mucosal Surfaces. Plos One, v. 3, n. 4, p. 2067, 2008.

SPINILLO, A.; CAPUZZOM, E.; GULMINETTI, R.; MARONE, P.; COLONNA, L.; PIAZZI, G. Prevalence of and risk factors for fungal vaginitis caused by non-albicans species. American Journal of Obstetrics Gynecology, v. 176, n. 1, p. 138-141, 1997.

STAIB, P., KRETSCHMAR, M., NICHTERLEIN, T., HOF, H. \& MORSCHHAUSER, J. Transcriptional regulators Cph1p and Efg1p mediate activation of the Candida albicans virulence gene SAP5 during infection. Infection and Immunity, v. 70, n. 2, 921-927, 2002.

ST-GERMAIN, G.; LAVERDIERE, M.; PELLETIER, R.; BOURGAULT, A. M.; LIBMAN, M.; LEMIEUX, C.; NOEL, G. Prevalence and antifungal susceptibility of 442 Candida isolates from blood and other normally sterile sites: results of a 2-year (1996 to 1998) multicenter surveillance study in Quebec, Canada. Journal Of Clinical Microbiology, v. 39, n. 3, p. 949-953, 2001.

SUGITA, T.; TAKASHIMA, M.; POONWAN, N.; MEKHA, N. Candida pseudohaemulonii $s p$. nov., an amphotericin B- and azole-resistant yeast species, isolated from the blood of a patient from Thailand. Microbiology and Immunology v. 50, n. 6, p. 469-473, 2006.

SULLIVAN, D. J.; MORAN, G. P.; COLEMAN, D. C. Candida dubliniensis: Ten years on. FEMS Microbiology Letters, v. 253, n. 1, p. 9-17, 2005.

SULLIVAN, D. J.; WESTERNENG, T. J.; HAYNES, K. A.; BENNET, D. E.; COLEMAN, D. C. Candida dubliniensis sp. nov.: phenotypic and molecular characterization of a novel species associated with oral candidosis in HIV-infected individuals. Microbiology, v. 141, n. 7, p. 1507-1521, 1995.

SUNDSTROM, P. Adhesion in Candida spp. Cellular Microbiology ${ }_{2}$ v. 8, p. 461-469, 2002.

TAVANTI, A.; DAVIDSON, A. D.; GOW, N. A. R.; MAIDEN, M. C. J. ODDS, F. C. Candida orthopsilosis and Candida metapsilosis spp. nov. To Replace Candida parapsilosis Groups II and III. Journal of Clinical Microbiology, v. 43, n. 1, p. 284-292, 2005.

TAY, S. T.; ABIDIN, I. A.; HASSAN, H.; NG, K. P. Proteinase, phospholipase, biofilm forming abilities and antifungal susceptibilities of Malaysian Candida isolates from blood cultures. Medical Mycology, v. 49, n. 5, p. 556-560, 2011. 
TORTORANO, A. M.; VIVIANI, M. A.; BARCHIESI, F.; ARZENI, D.; RIGONI, A. L.; COGLIATI, M.; COMPAGNUCCI, P.; SCALISE, G. Comparison of Three Methods for Testing Azole Susceptibilities of Candida albicans Strains Isolated Sequentially from Oral Cavities of AIDS Patients. Journal of Clinical Microbiology, v. 36, n. 6, p. 15781583, 1998.

TROFA, D.; GÁCSER, A.; NOSANCHUK, J. D.Candida parapsilosis, an Emerging Fungal Pathogen. Clinical Microbiology Reviews, v. 21, n. 4, p. 606-625, 2008.

TRTKOVA, C. J.; RACLAVSKY, V. Molecular-Genetic Approaches To Identification And Typing Of Pathogenic Candida Yeasts. Biomedical papers of the Medical Faculty of the University Palacký, Olomouc, Czechoslovakia, v. 150, n. 1, p. 51-61, 2006.

TUON, F. F.; COSTA, S. F. Rhodotorula infection: a systematic review of 128 cases from literature. Revista Iberoamericana de Micología, v. 25, p. 135-140, 2008.

US, E.; CENGIZ, S. A. Prevalence and phenotypic evaluation of Candida dubliniensis in pregnant women with vulvovaginal candidosis in a university hospital in Ankara. Mycoses, v. 50, n. 1, p. 13-20, 2007.

VAN ELDER, J.; JOOSTEN, L.; VERHAEGHE, A.; SURMONT, I. Fluconazole and amphotericin B antifungal susceptibility testing by National Committee for Clinical Laboratory Standards broth macrodilution method compared with Etest and semiautomated broth microdilution test. Journal Of Clinical Microbiology, v.34, n. 4, p. 842-847, 1996.

VAZQUEZ, J. A.; SANCHEZ, V.; DMUCHOWSKI, C.; DEMBRY, L. M.; SOBEL, J. D.; ZERVOS, M. J. Nosocomial acquisition of Candida albicans: an epidemiologic study. Journal of Infectious Diseases, v. 168, n. 1, p. 195-201, 1993.

VERMISKY, J. P.; SELF, M. J.; CHADMICK, S. G.; TRAMA J. P.; ADELSON, M. E.; MORDECHAI, E.; GYGAX, S. E. Survey of vaginal flora Candida species isolates from women of different age groups by use of species specific PCR detection. Journal Clinical Microbiology, v. 46, n. 4, p. 1501-1503, 2008.

WATSON, C.; CALABRETTO, H. Comprehensive review of conventional and nonconventional methods of management of recurrent vulvovaginal candidiasis. The Australian and New Zealand Journal of Obstetrics and Gynaecology, v. 47, n. 4, p. 262-272.

WHITE, T. C.; AGABIAN, N. Candida albicans secreted aspartyl proteinases : isoenzyme pattern is determined by cell type, and levels are determined by environmental factors. Journal of Bacteriology, v. 177, n. 18, p. 5215-5221, 1995. 
WHITE, S. J.; ROSENBACH, A.; LEPHART, P.; NGUYEN, D.; BENJAMIN, A.; TZIPORI, S.; WHITEWAY, M.; MESCAS, J.; KUMAMOTO, C. Self-regulation of Candida albicans population size during Gl colonization. PLoS Pathogens, v. 3, n. 12, p. 184, 2007.

WILLIAMS, D.; LEWIS, D. Pathogenesis and treatment of oral candidosis. Journal of Oral Microbiology, v. 3, p. 5771-5782, 2011.

XU, Z., CAO, Y. B.; ZHANG, J. D.; CAO Y. Y.; GAO, P.H.; WANG, D. J.; FU, X.P.; YING, K.; CHEN, W. S.; JIANG, Y.Y. cDNA array analysis of the differential expression change in virulence-related genes during the development of resistance in Candida albicans. Acta Biochimica et Biophysica Sinica, v. 37, n. 7, p. 463-472, 2005.

YANG, R.; WANG, W.; AO, J.; HAO, Z.; ZHANG, J.; WANG, C. Pathogenicity of Trichosporon asahii in a murine model of disseminated trichosporonosis. Chinese Medical Journal, v. 121, n. 24, p. 2557-2560, 2008.

ZIARRUSTA, G. B. Vulvovanitis candidiásica. Revista Iberoamericana de Micologia, v. 19, p. 22-24, 2002.

ZHAO, X.; OH, S. H.; CHENG, G.; GREEN, C. B.; NUESSEN, J. A.; YEATER, K. M.; LENG, R. P.; BROWN, A. J. P.; HOYER, L. L. ALS3 and ALS8 represent a single locus that encodes a Candida albicans adhesin; functional comparisons between Als3p and Als1p. Microbiology, v. 150, p. 2415-2428, 2004. 
ANEXOS 


\section{Anexo B}

Protocolo de Avaliação Clínica

$\mathrm{N}^{\mathrm{o}}$ Registro

Data:

Data menstruação:

Histórico de recorrência ( ) Sim ( ) Não

Uso de medicação (preencher no ato da coleta)

Antibióticos ( ) Sim

( ) Não

Qual?

Corticóide ( ) Sim

( ) Não

Qual?

Antifúngico ( ) Sim

( ) Não

Qual?

Hornônios ( ) Sim

( ) Não

Qual?

Anticoncepcionais ( ) Sim ( ) Não

Qual?

Avaliação Clínica (preencher durante a consulta)

Irritação vulvar com ardor

( ) Presente

( ) Ausente

Prurido

( ) Presente

( ) Ausente

Eritrema

( ) Presente

( ) Ausente

Corrimento

( ) Presente

( ) Ausente Cor:

Placas na vagina

( ) Presente

( ) Ausente

$\mathrm{pH}$ vaginal 


\section{Anexo C}

\section{Avaliação Laboratorial}

$\mathrm{N}^{\mathrm{o}}$ Registro

Data:

Exame direto: Leveduras ( ) Presente

( ) Ausente

Trichomonas

( ) Presente

( ) Ausente

\section{Coloração de Gram}

1, Células epiteliais ( ) Presente ( ) Ausente $n^{\circ}$.

2. Lactobacillus sp ( ) Presente ( ) Ausente $n^{\circ}$.

3. Clue cells ( ) Presente ( ) Ausente $n^{\circ}$.

4. Mobilluncus ( ) Presente ( ) Ausente $\mathrm{n}^{\circ}$.

5. Cocos Gram positivos ( ) Presente ( ) Ausente $n^{\circ}$.

6. Leveduras ( ) Presente ( ) Ausente $n^{\circ}$.

7. Hifas ( ) Presente ( ) Ausente $n^{\circ}$....

8. Outros .

\section{Cultura}

Ágar Sabouraud dextrose

( ) Negativa

( ) Positiva

Aspecto:

\section{CHROMagar Candida \\ ( ) Negativa \\ ( ) Positiva}

Cor:

Espécie: 


\section{Anexo A}

Instituto de Ciências Biomédicas da USP/SP

Termo de consentimento livre e esclarecido

(Obrigatório para Pesquisa Clínica em Seres Humanos - Resolução no 196 de 10/10/96 - CNS)

1. Dados de identificação do Paciente ou responsável legal

Nome do Paciente

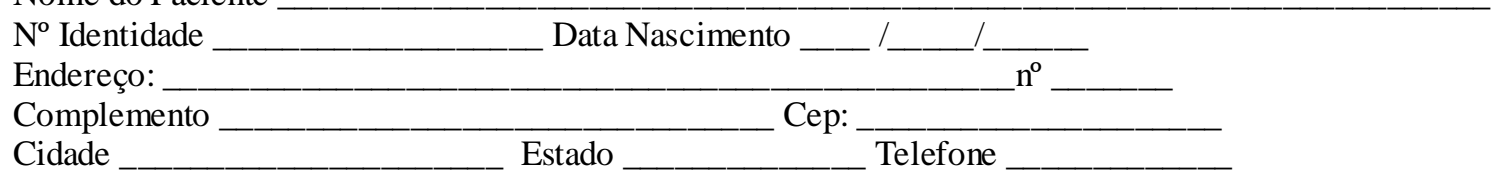

\section{Dados sobre o estudo}

Título: Candidiase vul vo vaginal:

Perfil fenotípico, genotípico, produção de proteinase (em meio solido e liquido) e sensibilidade aos antifúngicos de amostras de leveduras isoladas como colonizantes e como agentes de candidiase vul vovaginal primária e recorrente

Pesquisador Responsável Principal: Débora Moreira

Coordenador do Projeto: Prof ${ }^{a} \operatorname{Dr}^{a}$ Claudete Rodrigues Paula

Inicio do Estudo: 05/09/09

Duração: 5 anos

3. Explicações do pesquisador ao paciente ou representante legal

a) Esclarecimentos às mul heres

Candidíase vulvovaginal é uma das causas mais freqüentes de infecções que acometem as mulheres, atingindo aproximadamente $75 \%$ de todas as mulheres. Os principais sintomas provocados pelas infecções vaginais são corrimento, ardor intenso e coceira. A maior parte das mulheres apresentam infecções esporádicas, porém, algumas desenvolvem infecções difíceis de tratar, com vários episódios durante o ano, fato que compromete a qualidade de vida dessas mulheres.

\section{b) Justificativa e objetivo do projeto:}

Este projeto tem como objetivos verificar os fatores que podem causar candidíase e o que pode ser feito para melhorar os sinais e sintomas.

c) Procedimentos que serão utilizados e propósitos

Durante a consulta o médico colherá três amostras de secreção vaginal, com auxílio de um cotonete próprio para este fim. Além disso, a cada vez que você apresentar crises de vaginites, basta que você entre em contato com a nossa equipe e uma nova coleta será realizada.

d) Complicações e riscos esperados

A coleta da secreção vaginal é um procedimento indolor e não oferece riscos à sua saúde.

e) Benefícios obtidos

A sua participação, no estudo, não acarretará em custos e nem em pagamento de divisas, porém, além de receber um correto diagnóstico da infecção vaginal, você estará contribuindo para possíveis melhora na qualidade de vida de outras mulheres.

\section{RESPONDA:}

1. Fui esclarecida sobre a garantia de receber resposta a qualquer pergunta ou esclarecimento acerca dos procedimentos, riscos, benefícios e outros assuntos relacionados com a pesquisa e tratamento?
( ) SIM
( ) NÃO

2. Fui esclarecida sobre a liberdade de retirar meu consentimento a qualquer momento, sem que isso traga prejuízo quanto à continuidade do meu tratamento ou qualquer outro atendimento médico neste serviço?
( ) SIM
( ) NÃO

3. Fui esclarecida que não haverá remuneração financeira para minha inclusão no estudo?
( ) SIM
( ) NÃ̃ 
4. Fui esclarecida de que não haverá indenização além das previstas por lei, em reparação a dano imediato aos envolvidos no estudo?

( ) SIM

( ) NÃO

5. Fui esclarecida sobre a segurança de que minha identidade será preservada, mantendo-se todas as informações em caráter confidencial?

( ) SIM

( ) NÃO

6. Estou ciente de que os resultados desta pesquisa sejam favoráveis ou não, serão tornados públicos, sujeito a publicação científica?

( ) SIM

( ) NÃO

7. Fui esclarecida quanto aos benefícios e riscos destes tratamento e neste momento estou dando meu consentimento para participar dele como voluntária?

$\begin{array}{ll}\text { ( ) SIM ( ) NÃO } & \end{array}$

8. Fui esclarecida de que as amostras colhidas poderão ser armazenadas e utilizadas em estudos posteriores?

( ) SIM

V. Consentimento pós informado

( ) NÃO

Declaro que, após ter sido devidamente esclarecida sobre o projeto de pesquisa acima e informada sobre os riscos e benefícios do estudo, consinto em participar, na qualidade de paciente, deste projeto de pesquisa

São Paulo,

de

de

Assinatura do Paciente

Assinatura do Pesquisador

Fone: 30917294; 88784534 